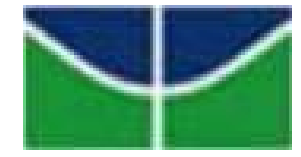

Universidade de Brasília

Faculdade de Economia, Administração, Contabilidade e Gestão Pública - FACE

Departamento de Economia

Programa de Pós-Graduação em Economia

Mestrado em Economia e Gestão do Setor Público

Edson Rodrigues da Silva

\title{
A ANÁLISE DA ADESÃO DA UNB AO REUNI: O CASO FCE E SUA CONTRIBUIÇÃO PARA A COMUNIDADE LOCAL
}


Edson Rodrigues da Silva

\section{A ANÁLISE DA ADESÃo DA UNB AO REUNI: O CASO FCE E SUA CONTRIBUIÇÃO PARA A COMUNIDADE LOCAL}

Dissertação apresentado ao Curso de Mestrado Profissional em Economia, área de concentração em Economia e Gestão do Setor Público, do Departamento de Economia da Faculdade de Economia, Administração, Contabilidade e Gestão de Políticas Públicas (FACE) da Universidade de Brasília (UnB) para obtenção do grau de Mestre.

Orientadora: Prof(a). Dra. Mireya Eugenia V.Perafan

BRASÍLIA, 


\title{
A ANÁlISE DA ADESÃO DA UNB AO REUNI: O CASO FCE E SUA CONTRIBUIÇÃO PARA A COMUNIDADE LOCAL
}

Dissertação de Mestrado Aprovada pela seguinte banca examinadora:

\author{
Prof ${ }^{\mathrm{a}}$. Dra . Mireya Eugenia Valencia Perafán \\ Faculdade de Agronomia e Medicina Veterinária/FAV \\ Orientadora \\ Prof. Dr. Luiz Fernando Macedo Bessa \\ Departamento de Gestão de Políticas Públicas - FACE - UnB \\ Membro Interno \\ Prof $^{\mathrm{a}}$. Dr ${ }^{\mathrm{a}}$. Doriana Daroit \\ Departamento de Administração - FACE - UnB \\ Membro Externo \\ Prof $^{\mathrm{a}}$. Dra ${ }^{\mathrm{a}}$. Magda de Lima Lúcio \\ Departamento de Gestão de Políticas Públicas - FACE - UnB \\ Membro Suplente
}

Brasília-DF, 12 de setembro de 2016. 


\section{DEDICATÓRIA}

Aos que anseiam por uma sociedade mais justa e solidária. 


\section{AGRADECIMENTOS}

Agradeço imensamente à Universidade de Brasília, pela oportunidade concedida.

À minha orientadora, Mireya Eugênia, pela paciência, pelas intervenções precisas e pelo árduo acompanhamento, com a qual aprendi inúmeras lições.

Aos membros da Banca examinadora: Professora Doriana e Professor Luiz Fernando Bessa, pela acolhida no convite para participar e pelas contribuições pessoais.

Aos professores do curso, representados pelas professoras Magda Lúcio e Andrea Cabello.

Aos colegas do curso, em especial, à Marcilene Barros e Roseane Aquino, com quem pude conviver ao longo dos últimos meses e cujas contribuições foram de importante valia.

Às Marias de minha Vida: Angélica e Eduarda, importantes pilares nos momentos de angústia.

Aos retirantes nordestinos com os quais pude acreditar na construção de um mundo melhor: Meu Pai, Francisco e minha Mãe, Zélia.

Aos meus 12 irmãos, representados no caçula e companheiro de luta e movimentos sociais: Damião.

Ao apoio dos amigos Saulo e Marlon, dos companheiros de trabalho, Alisson e Aliemar, dos demais servidores da FCE, representados nos colegas: Francis, Luiz, Mark, Telmo, Alexandre, Ana Paula, Fernanda, Maria Ivoneide, Márcia, Jean, Marco, Anderson, Pedro, Ana Paula, Alexandra, Lynce, e Flávia.

Aos servidores motoristas, Carlos, Ribamar e Delano, aos seguranças, Vilene, Helena, Fabiano, Mesaque, João e Pedro, e aos demais servidores que compõe o quadro de prestadores de serviço da FCE.

Aos professores da FCE, Josenaide, Gerson, Vanessa, Maria Hosana e Breitner. Enfim, ao Deus-Libertador, operador de justiça e de uma sociedade mais justa e solidária. 
“A Educação qualquer que seja ela, é sempre uma teoria do conhecimento posta em prática.”

Paulo Freire 


\section{RESUMO}

Compreender como as políticas de expansão do acesso à educação superior pública no Brasil e no Distrito Federal possibilitaram novas formas de relação entre comunidade acadêmica e os contextos urbanos em que novos campi foram inseridos, no caso específico, buscamos entender como a instalação do campus da universidade de Brasília (UnB) em Ceilândia (FCE), dedicado a diferentes áreas de saúde, possibilitou específicas condições de aproximação entre estudantes e professores universitários e determinados segmentos da população dessa localidade No presente trabalho, o foco da analise foram as relações entre os projetos/programas de extensão da FCE e a comunidade ceilandense. Realizamos um estudo quantitativo e exploratório do Projeto de extensão de Ação Contínua "Saúde Integral em Famílias Carentes do Distrito Federal" e do Programa de Extensão "Prevenção e reabilitação em idosos e adultos jovens cardiopatas ou não e sua inserção no esporte" com o objetivo de evidenciar a contribuição à comunidade local a partir destas ações de extensão.

Palavras-Chave: Reuni, UnB, FCE, Expansão, Democratização, Extensão. 


\begin{abstract}
This essay aims to understand how the expansion policies of access to public higher education in Brazil and in Distrito Federal have created new ways of relation between the academic community and the urban contexts where the new campi were inserted. In this specific issue, we will try to understand how the installation of the campus of the University of Brasília (UnB) in Ceilandia (FCE) - designed to different health areas - has made possible specific approach conditions between students and professors and determined Ceilandia's population segments. In this essay, the analysis focus will be on the relations between the extension projects/programs of FCE and the Ceilandia community. In different terms, we will have a quantitative and exploratory study of the extension project of continuous action 'Integral Health in Needy Families of Distrito Federal' and the Extension Program 'Prevention and rehabilitation of elderly and young adults - cardiac patients or not - and their insertion into sports' with the goal of showing the contribution to the local community based on these extension actions.
\end{abstract}

Key words: Gathered, UnB, FCE, Expansion, Democratization, Extension. 


\section{LISTA DE GRÁFICOS}

Gráfico 1- Evolução de Matrículas no Ensino Superior no Brasil ..................................................... 20

Gráfico 2 - Percentual de matrículas em Ies Públicas e Privadas................................................... 21

Gráfico 3 - Matrículas em IES privadas (comparação com ano anterior)................................... 22

Gráfico 4 - Evolução do número de cursos da UnB......................................................................... 36

Gráfico 5 - Evolução do Número de Matrículas UnB (1962 - 2014) ........................................... 37

Gráfico 6 - Taxa de Evasão nos cursos do campi FCE entre 2008/2 e 2014/2 ........................... 50

Gráfico 7 - Matrículas UnB (2009-2015)..................................................................................... 50

Gráfico 8 - Evasões UnB (2009-2015)......................................................................................... 51

Gráfico 9 - EVASÃO X NÚMERO DE MATRÍCULAS ............................................................... 52

Gráfico 10 - GRÁFICOS FORMADOS, POR ANO (EXLUSIVE FCE)................................... 52

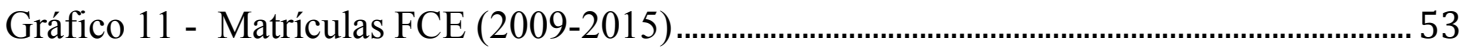

Gráfico 12 - Distribuição de Formados (por curso) ………………………....................................... 54

Gráfico 13 - Quantitativo de Projetos de Extensão de Ação Contínua (PEAC) na Universidade de Brasília (UnB x FCE) - 2013-2015 ....................................................................... 56

Gráfico 14 - Quantitativo de Projetos de Extensão de Ação Contínua (PEAC) na Universidade de Brasília (UnB x FCE) - 2015-2017 .................................................................... 56

Gráfico 15 - Comparativo de Projetos de Extensão de Ação Contínua (PEAC) entre os três

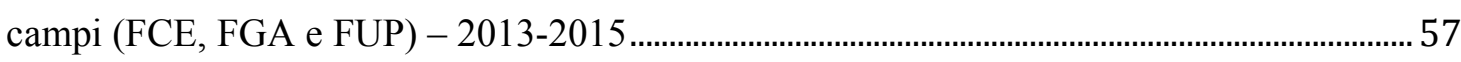

Gráfico 16 - Comparativo de Projetos de Extensão de Ação Contínua (PEAC) entre os 3 campi (FCE, FGA e FUP) - 2015-2017 ……………......................................................................... 58

Gráfico 17 - Localidade de realização dos Projetos de Extensão de Ação Contínua (PEAC)

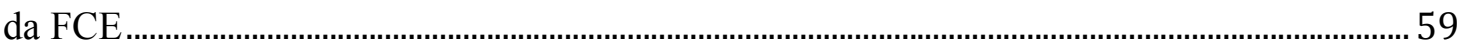

Gráfico 18 - Localidade de realização dos Projetos de Extensão de Ação Contínua (PEAC)

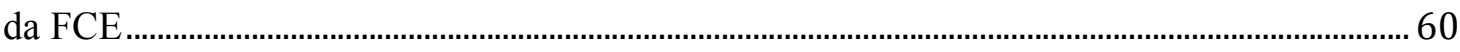

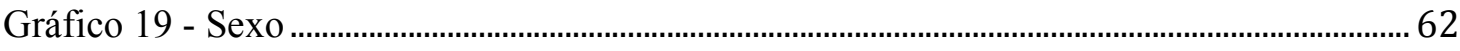

Gráfico 20 - Faixa Etária ............................................................................................................ 62 


\section{LISTA DE TABELAS}

Tabela 1 - Expansão das Universidades ........................................................................................... 31

Tabela 2 - Criação do Campi definitivo da FCE........................................................................... 44

Tabela 3 - Comparação entre o número de novos discentes e formados (2013-2015)............. 54

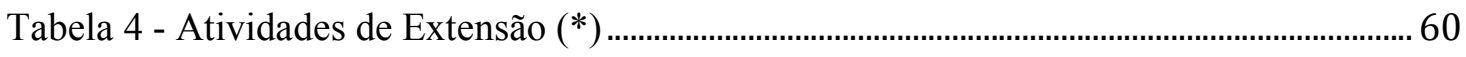




\section{LISTA DE ABREVIATURAS E SIGLAS}

\begin{tabular}{ll} 
CEM 4 & Centro de Ensino Médio 4 \\
CEPE & Conselho de Ensino, Pesquisa e Extensão \\
CF & Constituição Federal \\
Consuni & Conselho Universitário da UnB \\
DF & Distrito Federal \\
FCE & Faculdade de Ceilândia \\
FGA & Faculdade do Gama \\
FIES & Financiamento Estudantil \\
FIES & Financiamento Estudantil \\
FUB & Fundação Universidade de Brasília \\
FUP & Faculdade de Planaltina \\
ICC & Instituto Central de Ciências \\
IES & Instituição de Ensino Superior \\
JK & Juscelino Kubitscheck de Oliveira \\
LDB & Lei de Diretrizes e Bases da Educação \\
MEC & Ministério da Educação e Cultura \\
MESP & Módulo de Serviços e Equipamentos Esportivos \\
MPOUC & Movimento Pró Universidade Pública de Ceilândia \\
PDE & Plano de Desenvolvimento da Educação \\
PDI & Plano de Desenvolvimento Institucional \\
PEAC & Projeto de Extensão de Ação Contínua \\
PROUNI & Programa Universidade para Todos \\
Prouni & Programa Universidade para Todos \\
Reuni & Programa de Apoio a Planos de Reestruturação e Expansão das \\
SeSu & Universidades Federais \\
SIGRA & Secretaria de Educação Superior do Ministério da Educação \\
SPL & Sistema de Controle Acadêmico de Graduação \\
UAC & Secretaria de Planejamento \\
UED & Unidade Acadêmica \\
UFRJ & Unidade de Ensino e Docência \\
UFRJ & Universidade Federal do Rio de Janeiro \\
UnB & Universidade Federal do Rio de Janeiro \\
Unesco & Universidade de Brasília \\
& Organização das Nações Unidas para a Educação, a Ciência e a \\
& Cultura \\
& \\
\hline &
\end{tabular}




\section{SUMÁRIO}

1. INTRODUÇÃ

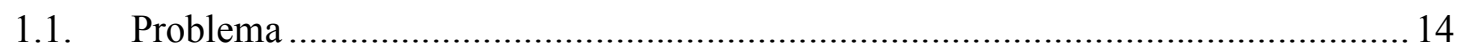

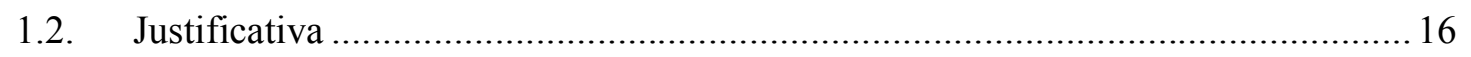

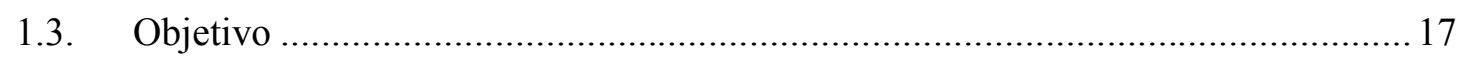

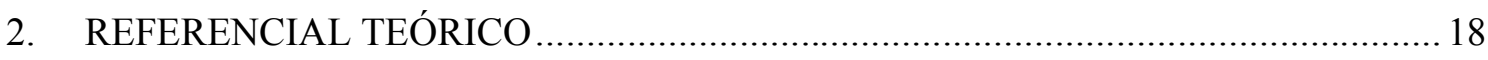

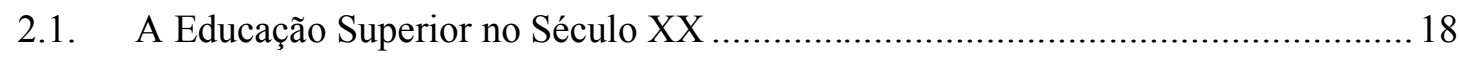

2.2. Democratização do acesso ao ensino superior .................................................. 22

2.3. Programa de Apoio a Planos de Reestruturação e Expansão das Universidades

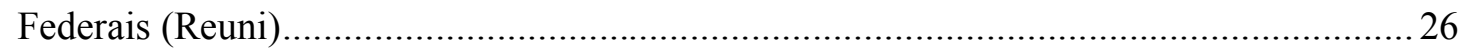

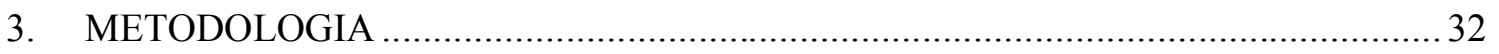

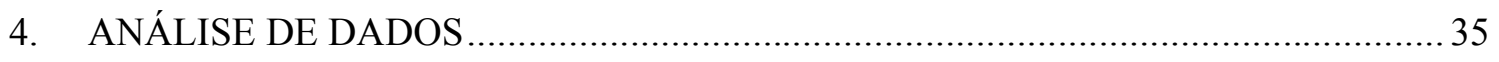

4.1. UnB: da Fundação à expansão ............................................................. 35

4.2. A Região Administrativa de Ceilândia............................................................ 39

4.3. A Faculdade de Ceilândia (FCE) …............................................................... 40

3.1 Análise das metas: Criação de novos cursos, com perfis interdisciplinares - e

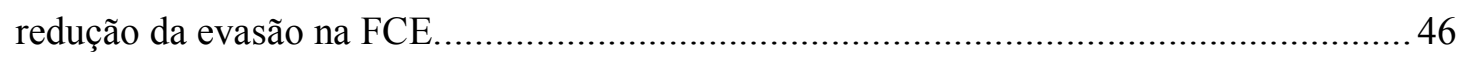

3.2 Criação de novos cursos e expansão dos já existentes, sobretudo no período noturno, como forma de melhorar o aproveitamento do espaço físico............................. 46

3.3 Abertura de novos cursos com perfis interdisciplinares - parcerias entre diferentes

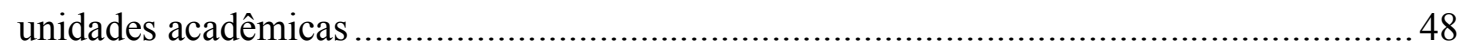

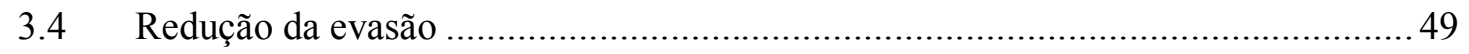

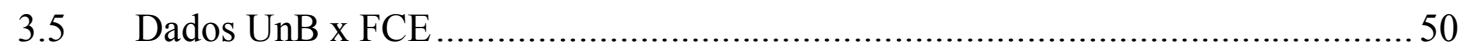

3.6 Projetos de Extensão de Ação Contínua (PEAC) da Faculdade de Ceilândia......... 55

3.7 Programas de Extensão e outras atividades de Extensão da Faculdade de Ceilândia..

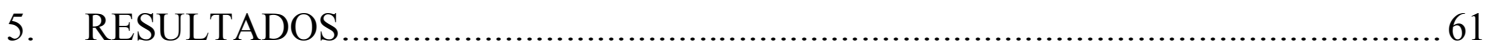

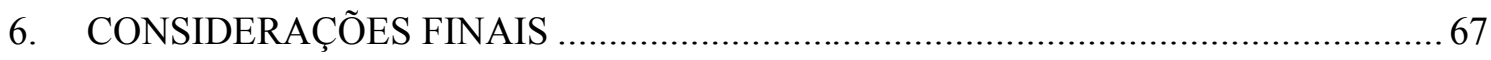

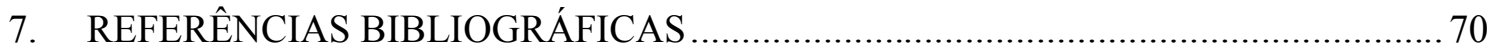

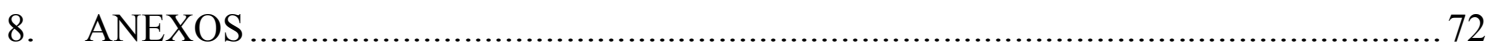




\section{INTRODUÇÃO}

Esta dissertação é apresentada no âmbito do Mestrado Profissional em Economia e Gestão do Setor Público da Universidade de Brasília (UnB) tendo como tema a análise da adesão da UnB ao Reuni: o caso da Faculdade de Ceilândia (FCE), onde serão abordados conceitos de democratização de acesso ao ensino superior, à expansão da Universidade de Brasília à Ceilândia e sua contribuição à população local, a partir dos Projetos de Extensão de Ação Contínua (PEAC).

Para explorar o tema Reuni e sua expansão da Universidade de Brasília (UnB) à cidade de Ceilândia, é importante contextualizar a educação superior pública brasileira desde a Reforma Universitária de 1968, as políticas públicas voltadas à educação ao longo do século XX, para o entendimento e reflexão na implantação do Reuni, em 2007.

O Programa de Apoio a Planos de Reestruturação e Expansão das Universidades Federais (Reuni) surge a partir da edição do Decreto $6096^{1}$ de 24 de abril de 2007 é uma das ações inseridas no Plano de Desenvolvimento da Educação (PDE), visando ampliar de forma significativa os recursos para a educação superior pública brasileira, proporcionando o aumento no quadro de recursos humanos (docentes, técnicos administrativos), e do número de vagas para estudantes, bem como melhorar a estrutura física das universidades públicas, onde sua meta global é a elevação na taxa de conclusão dos estudantes na ordem de $90 \%$ e diminuindo a evasão nos cursos superiores ${ }^{2}$.

O principal objetivo do Reuni, é "ampliar o acesso e a permanência na educação superior" ${ }^{3}$. Partindo desta premissa, o Reuni visa atacar problemas de falta de vagas, possibilitando a criação de cursos noturnos, novas universidades e novos campi das universidades públicas federais, bem como o reforço no orçamento para a construção das novas unidades, investimento em equipamentos e, por fim, em recursos humanos com a contratação de técnicos administrativos em educação e docentes para as mais variadas áreas.

1 http://www.planalto.gov.br/ccivil_03/_ato2007-2010/2007/decreto/d6096.htm

2 a elevação gradual da taxa de conclusão média dos cursos de graduação presenciais para noventa por cento e da relação de alunos de graduação em cursos presenciais por professor para dezoito, ao final de cinco anos, a contar do início de cada plano. (BRASIL, 2007a)

3 http://reuni.mec.gov.br/o-que-e-o-reuni 
A Universidade de Brasília (UnB) ao aderir ao Reuni em 2008, estabelece a expansão da universidade a três cidades do Distrito Federal (DF): Gama, Planaltina e Ceilândia, onde a expansão já era prevista no Plano de Desenvolvimento Institucional (PDI) de 2002 a 2006. Entre as metas propostas pelo Reuni à UnB:

- Criação de novos cursos e expansão dos já existentes, sobretudo no período noturno, como forma de melhorar o aproveitamento do espaço físico;

- Abertura de novos cursos com perfis interdisciplinares - parcerias entre diferentes unidades acadêmicas;

- Reestruturação pedagógica;

- Criação de mobilidade inter e intra-institucional;

- Criação de políticas de fortalecimento institucional;

- Redução da evasão;

- Ampliação da inclusão social;

- Fortalecimento das licenciaturas.

Quanto a expansão prevista para a Região Administrativa da Ceilândia, foi pactuada entre a $\mathrm{UnB}^{4}$ e a $\mathrm{SeSu} / \mathrm{MEC}^{5}$, a criação de 480 vagas anuais para 5 cursos (Enfermagem, Farmácia, Fisioterapia, Terapia Ocupacional e Saúde Coletiva) tendo início das atividades no segundo semestre de 2008.

\subsection{Problema}

A baixa escolarização no Brasil deve-se, entre outros fatores, ao surgimento tardio de cursos superiores, diferentemente dos demais países na América Latina (Cunha, 1980), onde já existia mais de vinte universidades desde seu período colonial. Pinto (2004) apresenta que:

[...] Não é de se estranhar que o Brasil apresente uma tão baixa Taxa de Escolarização Bruta na Educação Superior, mesmo quando comparada com aquela de nossos vizinhos latino-americanos.(Pinto, 2004).

A década de 1960 abriga, segundo Nogueira (2008) a principal reforma no ensino superior, que incidirão na política de expansão de vagas, principalmente no ensino superior privado.

\footnotetext{
${ }^{4}$ Plano de Reestruturação e Expansão da Universidade de Brasília 2008-2012.

${ }^{5}$ Secretaria de Educação Superior do Ministério da Educação.
} 
No âmbito das universidades federais houve reivindicações visando um novo modelo de organização universitária, tais como: abolição do sistema de cátedras vitalícias, modernização do ensino superior, organização do regime departamental, estruturação de carreira docente, entre outras, contempladas na Reforma Universitária de 1968.

A partir da redemocratização no Brasil, bem como a promulgação da Constituição Federal de 1988, cresceram os movimentos de reivindicação pelos mais diversos setores da sociedade por políticas públicas, possibilitando uma maior discussão sobre os mais variados temas, como meio ambiente, saúde, transportes, entre outros.

Com a expansão ocorrida no ensino médio na década de 1990, aumenta o pool de candidatos aos cursos superiores o que intensifica a pressão por ampliação de vagas nos cursos superiores públicos e gratuitos, tendo destaque, por exemplo, a política de ingressos de discentes a partir do sistema de cotas, em primeiro momento, pela comunidade negra, posteriormente, pelos mais diversos atores sociais, como estudantes oriundos de escolas públicas e indígenas.

A Universidade de Brasília foi a pioneira na aplicação da política de cotas para ingresso em cursos superiores nas universidades federais no Brasil em 2003 que contribuiu para a inclusão de novos atores na esfera da universidade pública.

[...] No início de junho de 2003, em concorrida reunião do Conselho de Ensino, Pesquisa e Extensão (Cepe) da UnB, foi aprovada na íntegra a proposta que destinava uma cota de $20 \%$ das vagas do vestibular para negros. (Maio \& Santos, 2005).

Além do sistema de cotas, a UnB previa a expansão e descentralização dos campi em seu Plano de Desenvolvimento Institucional (PDI) de 2002 a 2006, para as Cidades de Planaltina, Gama e Ceilândia.

Todavia, em 2006, em cumprimento de uma das metas previstas no PDI, deu-se início às atividades acadêmicas na Faculdade de Planaltina (FUP), com o primeiro ingresso de novos discentes nesta unidade. Em 2008, iniciam-se as atividades acadêmicas nos campi do Gama (FGA) e Ceilândia (FCE), onde a adesão da UnB ao Reuni, impulsionou a implementação destas novas unidades. 
Referente ao campi Ceilândia (FCE) teve início das atividades, a UnB expande dois cursos para a unidade: Enfermagem e Farmácia, e cria mais 3 novos cursos: Fisioterapia, Saúde Coletiva e Terapia Ocupacional, todos na área de saúde devido reinvindicações anteriores por movimentos sociais, como o Movimento Pró Universidade Pública de Ceilândia (MPOUC), informando a necessidade local para que a universidade cumpra seu papel institucional ${ }^{6}$.

Destaca-se que um grupo de professores da Faculdade de Ciências Saúde (UnB) foi responsável na construção do projeto da FCE, sendo que quatro professores foram designados a atuar na Ceilândia, o que facilitou, segundo Melo (2013), no entendimento acerca da estrutura da universidade bem como o diálogo com as demais áreas (acadêmica administrativa e financeira).

O item E das Diretrizes do Reuni aponta o compromisso social da instituição, a partir das políticas de inclusão, dos programas de assistência estudantil e das políticas de extensão universitária. Abordaremos este último item onde pretende-se responder: Qual a contribuição da UnB na Região Administrativa de Ceilândia, a partir de sua presença na comunidade local, por meio dos Projetos/Programas de Extensão?

\subsection{Justificativa}

O Reuni suscitou inúmeras pesquisas, artigos, reportagens, nas mais variadas universidades públicas federais brasileiras, dentre os quais, Sobrinho (2016) busca compreender o processo de implantação do Reuni na Universidade Federal do Tocantins (UFT) e na visão dos Gestores, como as diretrizes, estão sendo trabalhadas, Silveira (2015) analisa o Reuni e sua articulação com outras políticas para a educação superior nacional.

Teixeira (2013) avalia o impacto financeiro do Reuni na UnB, a partir de desdobramentos das metas alcançadas. Brito (2014), investiga ampliação de vagas e redução de evasão nas licenciaturas de Física, Letras, Matemática e Química, em sua pesquisa os limites da implementação do Reuni na UnB.

\footnotetext{
${ }^{6}$ A missão da UnB: Ser uma instituição inovadora, comprometida com a excelência acadêmica, científica e tecnológica formando cidadãos conscientes do seu papel transformador na sociedade, respeitadas a ética e a valorização de identidades e culturas com responsabilidade social. www.unb.br/sobre
} 
A pesquisa justifica-se uma vez que a não há investigação que identifique unicamente FCE e que responda sobre a democratização no acesso ao ensino superior bem como a contribuição da UnB para a comunidade local.

\subsection{Objetivo}

O Objetivo principal desta pesquisa é estudar e analisar a expansão da UNB na Ceilândia a partir da adesão do Reuni e sua contribuição para a comunidade local.

Os objetivos específicos são listados abaixo:

a) Investigar a quantidade de alunos ingressantes na graduação entre os anos de 2009 e 2015, destacando os residentes à Região Administrativa de Ceilândia neste período;

b) Analisar a contribuição dos cursos a comunidade local, tendo como ponto de análise os Projetos/Programas de Extensão; 


\section{REFERENCIAL TEÓRICO}

O presente capítulo trata do referencial teórico que embasará a presente pesquisa. Serão abordados conceitos sobre democratização, em particular, no acesso ao ensino superior público, a partir da implantação do Programa de Apoio a Planos de Reestruturação e Expansão das Universidades Federais (REUNI), a adesão pela Universidade de Brasília e o efeito desta expansão à cidade de Ceilândia.

A democratização do acesso ao ensino superior passa necessariamente pela recuperação da centralidade das universidades públicas, onde as instituições federais devem ser revigoradas, dotadas de efetiva autonomia administrativo-financeira e decididamente apoiadas pelo poder central, de modo a resgatar sua capacidade de funcionamento e expansão (Martins, 2009).

Para compreender a democratização no acesso à educação superior é importante destacar os movimentos de reformas educacionais ocorridas no Brasil no final da década de 1960 e início da década de 1970, a Reforma Universitária de 1968, bem como o processo histórico da educação superior entre as décadas de 1960 e 1990.

\subsection{A Educação Superior no Século XX}

A tentativa de criação de universidades brasileiras é barrada, desde o período colonial, por parte das elites portuguesas, justificando o projeto colonizador e das elites brasileiras considerando ir à Europa para a realização dos estudos superiores (Fávero 2006 apud Moacyr 1937).

Várias tentativas aconteceram no sentido de criar uma universidade no Brasil, desde os Jesuítas, até a vinda da família real ao Brasil, porém, sem êxito, denotando uma "política de controle por parte da Metrópole de qualquer iniciativa que vislumbrasse sinais de independência cultural e política da Colônia" (Fávero, 2006).

A primeira Universidade no Brasil é instituída a partir do Decreto $\mathrm{n}^{\circ} 14.343$, criando a Universidade Federal do Rio de Janeiro (UFRJ), em 20 de setembro de 1920, fazendo uma junção da Escola Politécnica, de Medicina e de Direito do Rio de Janeiro. Sendo o marco da criação das universidades, outras instituições universitárias foram criadas ao longo das décadas de 1920 e 1930. 
No contexto de criação das universidades surgem as primeiras organizações, entre elas a Associação Brasileira de Educação (ABE), no Rio de Janeiro, onde tiveram destaques nos planos políticos e culturais e tiveram forte influência na condução da política educacional do Estado brasileiro, tendo como fundadores engenheiros, advogados, médicos e professores - civis e militares e a Academia Brasileira de Ciências (ABC) onde suas atuações visavam a “concepção de universidade; funções que deverão caber às universidades brasileiras; autonomia universitária e modelo de universidade a ser adotado no Brasil”. (Fávero, 2006).

Fávero (2006) cita algumas questões acerca da Reforma Universitária de 1968: a mobilização estudantil, a partir de intensos debates nas universidades e manifestações de rua que ganha notoriedade a partir do Decreto 62.937, de 2 de julho de 1968, criando o Grupo de Trabalho (GT) que vai culminar na edição da lei no 5.540, de 28 de novembro de 1968, a Reforma Universitária.

No período que compreende as décadas de 1960 e final da década de 1970 houve a criação de 27 universidades federais em todo o território brasileiro, mas a ampliação considerável no número de matrículas se deu na década de 1970, entre os vários fatores podemos destacar a forte concentração populacional nos centros urbanos, aliados a uma enorme demanda de mão-de-obra qualificada para a indústria em expansão (Vasconcelos, 2010).

Na década de 1970, o número de matrículas no ensino superior passou de pouco mais de 400 mil, para quase 1,4 milhão de novas matrículas em 1980 (gráfico 1). Este aumento foi facilitado a partir da Reforma Universitária de $1968^{7}$, que, conforme Martins (2009) produziu efeitos paradoxais: modernização das universidades públicas e condições para o surgimento de ensino superior privado.

[...]Por um lado, modernizou uma parte significativa das universidades federais e determinadas instituições estaduais e confessionais, que incorporaram gradualmente as modificações acadêmicas propostas pela Reforma. Criaram-se condições propícias para que determinadas instituições passassem a articular as atividades de ensino e de pesquisa, que até então - salvo raras exceções - estavam relativamente desconectadas. Aboliram-se as cátedras vitalícias, introduziu-se o regime departamental, institucionalizou-se a carreira acadêmica, a legislação pertinente acoplou o ingresso e a progressão docente à titulação acadêmica. (Martins, 2009)

\footnotetext{
${ }^{7}$ Anterior à Lei ${ }^{\circ}$ 5.540, foi publicado o Decreto-Lei $n^{\circ} 62.937$ de 2 de julho de 1968, estabelecendo o Grupo de Trabalho (GT) a partir do, por 11 membros do Ministério da Educação e Cultura (MEC) e designados pelo Presidente da República visando a discussão sobre o sistema de educação superior no Brasil, convocando a comunidade acadêmica (estudantes, docentes, cientistas, especialistas em educação superior) e demais setores da sociedade civil e governamental, para colaborar no estudo e preparo dos estudos e projetos cujos resultados são de" alta prioridade e relevante interesse nacional (art. $\left.3^{\circ}\right)$ ".
} 
Neste período, nota-se que o aumento de vagas contempla principalmente as Instituições de Ensino Superior Privadas, onde Governo viu-se forçado à aprovação na criação de novos cursos, sob a autorização do Conselho Federal de Educação.

Se por um lado, houve um aumento substancial do número de matrículas na década de 1970, consequentemente, entre 1980 e 1995, houve uma diminuição na efetivação de matrículas, partindo de cerca de 1,4 milhão para pouco mais de 1,5 milhão, em 1990, muito decorrente da forte recessão, marcada por altos índices de inflação, elevadas taxas de desemprego, entre outros indicadores.

Gráfico 1- Evolução de Matrículas no Ensino Superior no Brasil

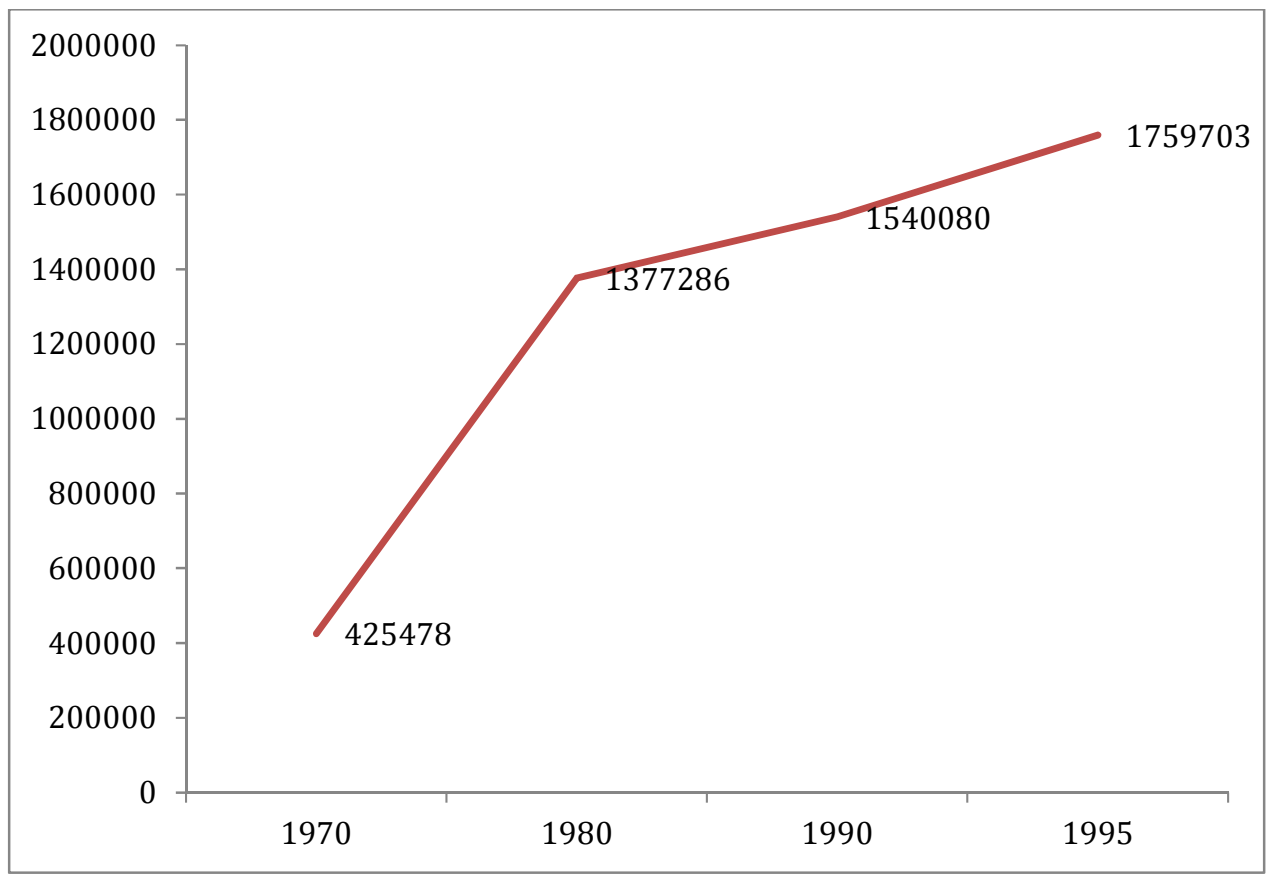

Fonte: MEC/INEP Elaborado pelo autor

É importante destacar que o ingresso de novos discentes em cursos superiores citados anteriormente refere-se às instituições públicas e privadas. Se por um lado, as instituições públicas dominavam o cenário de matrículas antes de 1970, o período posterior vai apontar o domínio de matrículas em instituições privadas. 
O Gráfico 2 apresenta, em números percentuais, a evolução de matrículas entre 1960 e 1994, dividido em duas categorias: Matrículas em Instituições de Ensino Superior Públicas e Privadas.

Gráfico 2 - Percentual de matrículas em Ies Públicas e Privadas

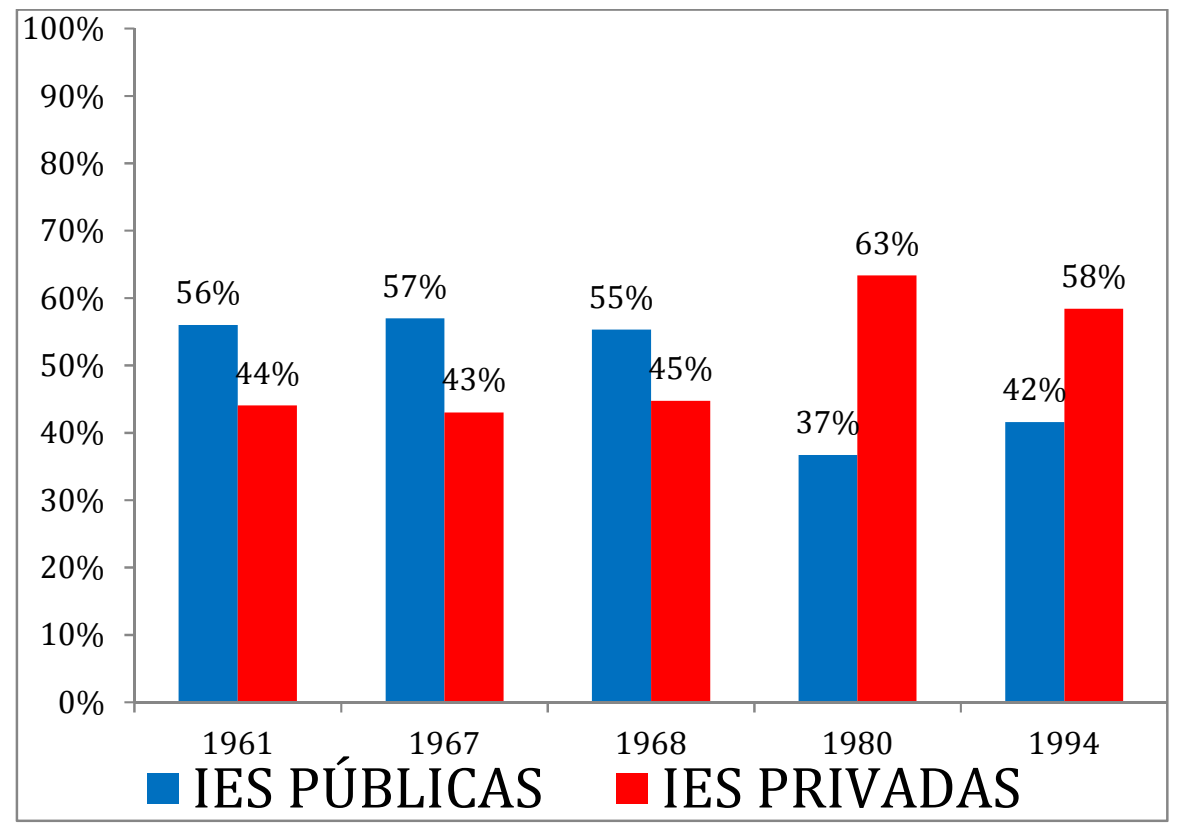

Fonte: MEC/INEP, Elaborado pelo autor

Sguissardi (2008) apresenta algumas reflexões acerca deste fenômeno:

[...] 1.Ao se implantar no país o regime militar-autoritário, a cobertura do sistema era mínima e ainda predominavam as matrículas em IES públicas à razão de $61,6 \%$ contra $38,4 \%$ do contingente de estudantes nas IES privadas, em geral confessionais. Para um total de 142 mil matrículas, 87 mil eram públicas e 54 mil, privadas.

[...] 2. Com ponto de partida tão baixo, a tarefa do crescimento foi até certo ponto facilitada; nos primeiros 10 anos do regime, esse montante foi multiplicado por mais de cinco vezes, passando de 142 mil para 937 mil matrículas (aumento de 559,8\%). Sob o "espírito" do regime político, ocorre deforma marcante o primeiro grande movimento de privatização do sistema. As matrículas públicas tiveram um crescimento muito inferior à média $(289,1 \%)$ e muito distante do crescimento das matrículas privadas $(990,1 \%)$, o que fez mais do que se inverterem as proporções da década anterior: são agora $36,4 \%$ as matrículas públicas e $63,6 \%$ as privadas.

Apesar da diminuição na oferta de vagas nos anos 1980, há uma retomada na oferta de matrículas na segunda metade da década de 1990, muito influenciada pela pressão oriunda do aumento de egressos de formação em níveis médio, aliado à influência de políticas 
neoliberais num processo econômico de intensificação do mercado financeiro onde o mercado autorregulado dita as normas competitivas da sociedade.

\subsection{Democratização do acesso ao ensino superior}

No Final da década de 1990 e início do século XXI, há uma retomada no crescimento do número de matrículas, basicamente no ensino superior privado. Entre 1999 e 2013, em função do Financiamento Estudantil (FIES), num primeiro momento, seguidos do Programa Universidade para Todos (Prouni), houve um aumento em 3.180.183 novas matrículas nas IES particulares, representando um crescimento anual em $17 \%$.

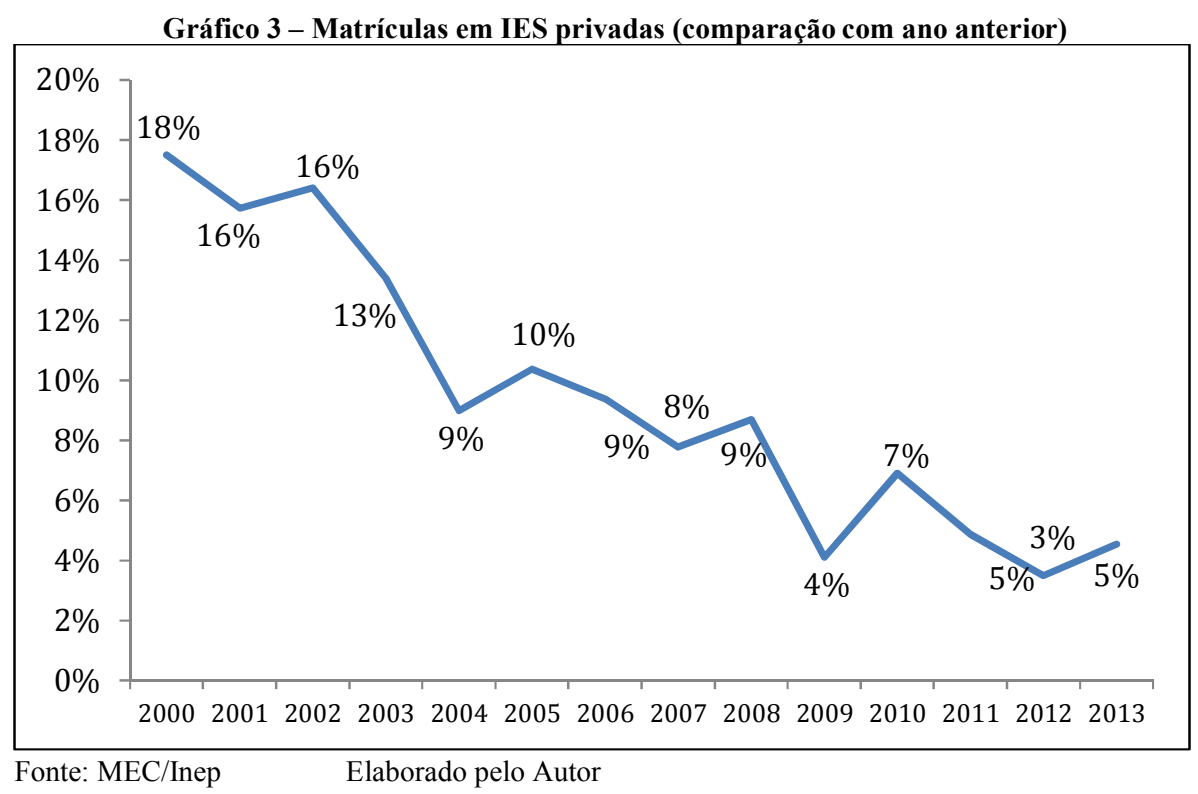

O Gráfico 3 apresenta a variação percentual de matrículas em Instituições de Ensino Superior privadas em relação ao ano anterior. Nota-se que, do ano 2000 houve um acréscimo em $18 \%$ de novas matrículas em relação ao ano de 1999 , o ano de 2001 , acréscimo em $16 \%$ em relação a 2000, e assim sucessivamente. A partir do ano de 2004, este percentual cai para a metade $(9 \%)$ e segue uma tendência de diminuição em função de um crescimento de novas matrículas no ensino superior público sob a égide da expansão e interiorização de novos 
campi das universidades federais, bem como a atuação direta do Programa de Apoio a Planos de Reestruturação e Expansão das Universidades Federais (Reuni).

Anterior à implementação e adesão, por parte das universidades federais ao programa Reuni, destacam-se algumas ações de ingresso ao ensino superior, público e privado, com vistas ao preenchimento de novas vagas em graduações das mais diversas áreas.

\section{$\underline{\text { Sistema de cotas }}$}

Segundo Gomes (2001), os objetivos das ações afirmativas são: induzir transformações de ordem cultural, pedagógica e psicológica, visando a tirar do imaginário coletivo a ideia de supremacia racial versus subordinação racial e/ou de gênero; coibir a discriminação do presente; eliminar os efeitos persistentes (psicológicos, culturais e comportamentais) da discriminação do passado, que tendem a se perpetuar e que se revelam na discriminação estrutural; implantar a diversidade e ampliar a representatividade dos grupos minoritários nos diversos setores; criar as chamadas personalidades emblemáticas, para servirem de exemplo às gerações mais jovens e mostrar a elas que podem investir em educação, porque teriam espaço.

Essas ações afirmativas provocaram um embate, por ser uma proposta de reforma no sistema educacional. Podemos observar que ao longo do tempo e após tantas discussões e experiências com as políticas de ações afirmativas ainda há muito a ser feito para se combater a evasão dos grupos menos favorecidos na educação.

Mas para os estudantes que ingressaram por meio dessas políticas públicas causou e continua causando um impacto no que se refere à inserção dos ingressantes em outros meios que proporcionou melhores condições de vida, os quais tinham dificuldades de acesso.

Acerca do acesso ao ensino superior nas universidades públicas para as classes baixas esses programas têm gerado polêmicas, por ser um programa que propõe mudanças no meio acadêmico e tem seus princípios de referência acesso para todos no ensino superior, pois inserindo as classes desfavorecidas no ensino superior lhe dá a possibilidade de ingresso e melhoria de vida (econômica, social) na sociedade. 
O Estudo deixou claro que mesmo após uma década de existência de programas, leis e políticas públicas que buscam a igualdade para todos ainda temos muito a melhorar no meio acadêmico para amenizar o problema do nosso sistema educacional brasileiro.

\section{Financiamento Estudantil (FIES)}

O Fundo de Financiamento Estudantil (Fies) é um programa do Ministério da Educação que custeia o curso de graduação em Instituições de Ensino Superior privadas ao aluno que, em contrapartida, compromete-se com o pagamento futuro, após período de carência (18 meses após o término do curso) em longo período, o que permite ao estudante inserir num mercado de trabalho, de forma qualificada e possibilitando o pagamento futuro deste empréstimo. ${ }^{8}$

Em 2010, o FIES passou a funcionar em um novo formato: a taxa de juros do financiamento passou a ser de 3,4\% a.a., o período de carência passou para 18 meses e o período de amortização para 3 (três) vezes o período de duração regular do curso +12 meses. O Fundo Nacional de Desenvolvimento da Educação (FNDE) passou a ser o Agente Operador do Programa para contratos formalizados a partir de 2010. Além disso, o percentual de financiamento subiu para até $100 \%$ e as inscrições passaram a ser feitas em fluxo contínuo, permitindo ao estudante o solicitar do financiamento em qualquer período do ano.

A partir do segundo semestre de 2015, os financiamentos concedidos com recursos do Fies passaram a ter taxa de juros de 6,5\% ao ano com vistas a contribuir para a sustentabilidade do programa, possibilitando sua continuidade enquanto política pública perene de inclusão social e de democratização do ensino superior. O intuito é de também realizar um realinhamento da taxa de juros às condições existentes no ao cenário econômico e à necessidade de ajuste fiscal.

\section{Programa Universidade para Todos (Prouni)}

O Programa Universidade para Todos (Prouni) é uma ação do governo federal, por meio do Ministério da Educação (MEC) quem tem por objetivo subsidiar, a partir de

\footnotetext{
${ }^{8}$ O FIES é destinado a financiar a graduação na educação superior de estudantes matriculados em cursos superiores não gratuitas na forma da Lei 10.260/2001. Podem recorrer ao financiamento os estudantes matriculados em cursos superiores que tenham avaliação positiva nos processos conduzidos pelo Ministério da Educação.
} 
concessão de bolsas em cursos de graduação em Instituições de Ensino Superior privadas, quer sejam parciais ou totais. Foi instituído em janeiro de $2005^{9}$ e conta, dentre os requisitos, que o candidato tenha cursado o ensino médio em escola pública, ou, em rede privada desde que na condição de bolsista, ou ser pessoa com deficiência, entre outros.

A partir destes dados, acerca do processo de inserção de novos discentes no ensino superior permite fazer uma reflexão acerca do conceito de democratização do acesso ao ensino superior.

O conceito de democratização do acesso à educação superior é polissêmico, dependendo do entendimento do autor que trata o tema e do cenário político vivenciado em determinado momento da história. Democratizar o acesso significa, em uma primeira instância, a ampliação de vagas na educação superior, seja pela criação de novas instituições, seja pela oferta de mais vagas nas instituições de educação superior existentes, de modo que pessoas de grupos sociais diversos tenham acesso. (Nogueira, 2008).

A democratização do acesso pressupõe perceber o campo de disputa ao qual está relacionado sendo diretamente ligado à orientação político-econômico e seus defensores. Sobrinho (2010) apresenta duas as lógicas hegemônicas e que disputam este espaço: A educação como mercadoria e a educação como bem público.

A Educação torna-se tema central na agenda das políticas públicas e tendo por pressuposto da expansão da escolarização da população:

A democratização da educação adquiriu centralidade na agenda das políticas públicas dos Estados, nos programas dos organismos multilaterais e nos movimentos sociais de diferentes matizes e de distintas partes do mundo. A meta mais relevante dessa agenda é a expansão da escolaridade da população em geral. Desde meados do século passado, a teoria do capital humano e a teoria residual do desenvolvimento postulavam a importância da educação como fator decisivo do desenvolvimento econômico. (Sobrinho, 2013).

\footnotetext{
${ }^{9}$ BRASIL, 2005. Lei no 11.096, de 13 de janeiro de 2005.
} 
Dourado (2011), Ristoff (2003), entre outros pesquisadores, defendem um fortalecimento das políticas de acesso ao ensino superior público e gratuito, argumentando que para democratizar o acesso é importante a criação e expansão de matrículas nas universidades públicas incentivando a pesquisa e a extensão indissociáveis do ensino e tece críticas à expansão do ensino privado que, segundo Ristoff (2003) torna-se um "cenário de privatização da educação superior no país; a existência de grande número de instituições de qualidade questionável; a necessidade de consolidação da expansão pública” e,

aliado a um esforço de se implementar novos processos de gestão e de regulação que direcionem o fundo público para a expansão e democratização da educação superior pública e gratuita no país, deve-se garantir políticas e ações direcionadas à regulação e gestão do sistema que contribuam para a melhoria da qualidade e para a progressiva desmercantilização da educação superior privada. (Dourado, 2011)

Nogueira (2008) apresenta que, em princípio, o conceito referente à democratização do acesso ao ensino superior pode ser entendido como a criação de novas vagas, quer seja no ensino público ou privado.

Sobrinho (2013) apresenta ainda que a educação é um bem público, partindo do pressuposto da educação, cuja finalidade é fundamental para a formação do indivíduo tendo como resultados o aperfeiçoamento da cidadania e da democratização da sociedade.

A partir destes autores, e para fins desta dissertação assumimos que a democratização do ensino compreende a ampliação do número de matrículas no ensino superior público, sua expansão para novas localidades, abrangendo o máximo de municípios, tendo por pressuposto a educação como um bem público.

\subsection{Programa de Apoio a Planos de Reestruturação e Expansão das Universidades Federais (Reuni)}

A reflexão acerca da universidade pública brasileira, seus desdobramentos, ampliação de vagas, surgimento de instituições particulares de ensino, possibilitando o acesso de novos atores num contexto de graduação, com considerável ampliação de atuação 
principalmente a partir da Reforma Universitária de 1968, perpassando as décadas de 1970, a diminuição no quadro de matrículas entre os anos de 1980 e 1995, quer seja em universidades públicas, quer seja em Instituições particulares de ensino e o papel das políticas afirmativas, novo financiamento (FIES) e o subsídio de bolsas a partir do Prouni, permitem compreender a criação do Programa de Apoio a Planos de Reestruturação e Expansão das Universidades Federais (REUNI).

A década de 1980 marca o retorno do governo civil (1985) e o surgimento de vários partidos políticos, ampliando o debate das eleições diretas e de uma nova constituinte, que culmina com a Constituição Federal de 1988, onde amplia os direitos e proporciona uma nova diretriz à educação, em especial, ao ensino superior, consolidando a autonomia universitária e a indissociabilidade entre ensino, pesquisa e extensão:

A Constituição de 1988 incorporou várias das reivindicações relativas ao ensino superior. Consagrou a autonomia universitária, estabeleceu a indissociabilidade entre ensino pesquisa e extensão, garantiu a gratuidade nos estabelecimentos oficiais, assegurou o ingresso por concurso público e o regime jurídico único. Nesse contexto a demanda dos dirigentes de instituições de ensino superior públicas e de seu corpo docente encaminhou-se na direção de uma dotação orçamentária que viabilizasse o exercício pleno da autonomia e, da parte dos alunos e da sociedade, de modo geral, o que se passou a reivindicar foi a expansão das vagas das universidades públicas. (Saviani, 2010).

Saviani (2010) argumenta que o "modelo napoleônico" 10 de educação superior que surgiu desde a criação dos primeiros cursos passando pela reforma Francisco Campos (1931) e com a Reforma Universitária de 1968, tendo como principais características, a "forte presença do Estado na organização e regulação superior, em especial, no caso das universidades" sendo matéria de discussão na Constituição de 1988 e consagrado na Lei de Diretrizes e Bases da Educação (LDB) de 1996.

A LDB/96 definiu que o Executivo Federal enviasse ao Congresso Nacional o Plano Nacional de Educação, onde:

É instituída a Década da Educação, a iniciar- se um ano a partir da publicação desta Lei. A União, no prazo de um ano a partir da publicação desta Lei, encaminhará, ao Congresso Nacional, o Plano Nacional de Educação, com diretrizes e metas para os dez anos seguintes, em sintonia com a Declaração Mundial sobre Educação para Todos. (BRASIL, 1996).

\footnotetext{
${ }^{10}$ Saviani (2010) apresenta, em seu texto 3 modelos históricos de universidades: a) napoleônico, anglo-saxônico e prussiano assentados nos elementos básicos que constitui as universidades modernas: o Estado, a sociedade civil e a autonomia da comunidade interna à instituição. O Modelo napoleônico é um modelo que prima pelo ensino profissional, formando burocratas para atuar no Estado.
} 
O Plano Nacional de Educação (PNE) foi aprovado pela lei 10.172/2001 e traz um diagnóstico da educação brasileira em todos os seus níveis, em particular no ensino superior, indica o baixo índice de acesso à cursos superiores no Brasil, principalmente no ensino público.

O PNE tem como um de seus objetivos a ampliação da oferta de vagas ao ensino superior para, no mínimo, 30\% dos jovens entre 18 e 24 anos, em detrimento à situação anterior que chegava a $12 \%$.

No conjunto da América Latina, o Brasil apresenta um dos índices mais baixos de acesso à educação superior, mesmo quando se leva em consideração o setor privado. Assim, a porcentagem de matriculados na educação superior brasileira em relação à população de 18 a 24 anos é de menos de 12\%, comparando-se desfavoravelmente com os índices de outros países do continente. A Argentina, embora conte com $40 \%$ da faixa etária, configura um caso à parte, uma vez que adotou o ingresso irrestrito, o que se reflete em altos índices de repetência e evasão nos primeiros anos. Mas o Brasil continua em situação desfavorável frente ao Chile $(20,6 \%)$, à Venezuela ( $26 \%$ ) e à Bolívia ( 20,6\%). (Brasil, 2001).

Particularmente, em referência às universidades públicas, o documento aponta a necessidade de expansão de vagas com vistas ao atendimento da demanda crescente, dando prioridades aos alunos carentes, e que:

Deve-se assegurar, portanto, que a setor público neste processo, tenha uma expansão de vagas tal que, no mínimo, mantenha urna proporção nunca inferior a $40 \%$ do total. (Brasil, 2001).

No documento Diretrizes do Reuni estão contidos os principais motivos pelos quais urgia a necessidade em ampliar o número de vagas no ensino superior público, bem como a expansão e interiorização de novos campi em todo o Brasil.

O documento destaca que apesar da ampliação significativa de matrículas em curso superior na segunda metade da década de 1990, estas foram eminentemente em instituições privadas de ensino e apresenta um "esgotamento, principalmente pela saturação de mercado em várias profissões e pela inadimplência de segmentos sociais incapazes de arcar com o alto custo da educação superior" (Brasil, 2007) destacando que: 
[...] a ampliação das vagas na educação superior pública torna-se imperativa para o atendimento da grande demanda de acesso à educação superior. (Brasil, 2007).

O documento aponta, ainda, que, a Reforma Universitária de 1968 proporcionou concepções fragmentadas de conhecimento cursos de graduação voltados ao viés disciplinar, e bastante inflexível, acentuados pela profunda distância entre os ensinos de graduação e pósgraduação.

A estrutura curricular reforça a lógica de "precocidade profissional", onde a imaturidade na escolha da carreira profissional, aliada a um "sistema de seleção pontual e socialmente excludente" para o ingresso nos cursos superiores, apresentam um grande risco para o país, onde:

[...] coloca o país em risco de isolamento nas esferas científica, tecnológica e intelectual de um mundo cada dia mais globalizado e inter-relacionado. (Brasil, 2007b).

Problemas também são apontados no plano operacional, repetindo, aprofundando e ampliando na estrutura herdada do século XX. Entre os problemas encontrados, segundo as Diretrizes Gerais do Reuni (Brasil, 2007), destaca-se que os cursos têm uma orientação quase que exclusiva voltada à formação profissional, não tendo, portanto, abertura para uma interdisciplinaridade e flexibilidade, dificuldades de propostas inovadoras, devido às regras quem compõe o currículo, dificuldades políticas no interior das universidades, dificuldades financeiras, na aplicação das políticas de ações afirmativas, junto aos estudantes oriundos de classes menos favorecidas, falta de uma prática pedagógica que contemple os recursos didáticos, utilizando de práticas tradicionais nas aulas expositivas. Ociosidade em salas de aulas no período noturno e, no caso de cursos diurnos, os elevados índices de evasão.

Para a superação dos problemas elencados nas Diretrizes (Brasil, 2007b), são necessárias ações que permitem inserir a educação superior para suprir as demandas dos novos desafios da sociedade do conhecimento, e para isto, são necessárias mudanças na antiga estrutura acadêmica onde o Reuni, apoiado pela Lei de Diretrizes e Bases da Educação, visam apresentar modelos de formação abrangentes, flexíveis e integradores.

A concepção do Reuni está diretamente ligada ao Plano de Desenvolvimento da Educação (PDE) um programa que visa expandir a atuação das universidades públicas, juntamente com a ampliação de vagas no ensino superior público, tendo por diretrizes: 
I - Redução das taxas de evasão, ocupação de vagas ociosas e aumento de vagas de ingresso, especialmente no período noturno.

II - Ampliação da mobilidade estudantil, com a implantação de regimes curriculares e sistemas de títulos que possibilitem a construção de itinerários formativos, mediante o aproveitamento de créditos e a circulação de estudantes entre instituições, cursos e programas de educação superior.

III - Revisão da estrutura acadêmica, com reorganização dos cursos de graduação e atualização de metodologias de ensino-aprendizagem, buscando a constante elevação da qualidade.

IV - Diversificação das modalidades de graduação, preferencialmente não voltadas à profissionalização precoce e especializadas.

V - Ampliação de políticas de inclusão e assistência estudantil.

VI - Articulação da graduação com a pós-graduação e da educação superior com a educação básica.

O Reuni apresenta, ainda, nas suas Diretrizes Gerais (Brasil, 2007b) as seis

dimensões que deverá ser combinada com o plano de reestruturação de cada universidade:

(A) Ampliação da Oferta de Educação Superior Pública

1. Aumento de vagas de ingresso, especialmente no período noturno;

2. Redução das taxas de evasão; e

3. Ocupação de vagas ociosas.

(B) Reestruturação Acadêmico-Curricular

1. Revisão da estrutura acadêmica buscando a constante elevação da qualidade;

2. Reorganização dos cursos de graduação;

3. Diversificação das modalidades de graduação, preferencialmente com superação da profissionalização precoce e especializada;

4. Implantação de regimes curriculares e sistemas de títulos que possibilitem a construção de itinerários formativos; e

5. Previsão de modelos de transição, quando for o caso.

(C) Renovação Pedagógica da Educação Superior

1. Articulação da educação superior com a educação básica, profissional e tecnológica;

2. Atualização de metodologias (e tecnologias) de ensino-aprendizagem;

3. Previsão de programas de capacitação pedagógica, especialmente quando for o caso de implementação de um novo modelo.

(D) Mobilidade Intra e Inter-Institucional

1. Promoção da ampla mobilidade estudantil mediante o aproveitamento de créditos e a circulação de estudantes entre cursos e programas, e entre instituições de educação superior;

(E) Compromisso Social da Instituição

4. Políticas de inclusão;

5. Programas de assistência estudantil; e

6. Políticas de extensão universitária.

(F) Suporte da pós graduação ao desenvolvimento e aperfeiçoamento qualitativo dos cursos de graduação

1. Articulação da graduação com a pós-graduação: Expansão quali-quantitativa da pós-graduação orientada para a renovação pedagógica da educação superior

Ao assumirmos a educação como um bem público, destacamos o item $\mathrm{E}$ das dimensões elencadas, a partir do compromisso social, buscaremos, analisar um programa e um projeto de extensão executados na Região Administrativa de Ceilândia e sua contribuição à comunidade local. 
De acordo com Araújo e Pinheiro (2010) o Reuni tem como propósito gerar um aporte financeiro para as universidades federais brasileiras criando condições para a expansão de vagas, redução de evasão, melhoria da estrutura física, aquisição de máquinas e equipamentos, seleção de pessoal (técnicos administrativos e docentes) bem como a ampliação de políticas de inclusão e de assistência estudantil.

Um destaque de grande importância para adesão de cada universidade pública federal é a autonomia universitária, explicitada no art. $4^{\mathrm{o}}$ :

O plano de reestruturação da universidade que postule seu ingresso no Programa, respeitados a vocação de cada instituição e o princípio da autonomia universitária, deverá indicar a estratégia e as etapas para a realização dos objetivos referidos no art. 1o. Parágrafo único. O plano de reestruturação deverá ser aprovado pelo órgão superior da instituição.

Ressalta-se ainda que cada Instituição Federal de Ensino Superior possa requerer a qualquer tempo sua adesão ao Reuni desde que respeitada autonomia universitária, contendo o plano de reestruturação e estimativa de recursos para atendimento das metas ora estabelecidas.

O Reuni ampliou de forma significativa o número de universidades públicas tanto em construção de novas Instituições quanto a novos campi. A expansão teve um impacto direto na atuação universitária em novos municípios. A tabela 1 indica esta ampliação:

Tabela 1 - Expansão das Universidades

\begin{tabular}{|l|c|c|c|}
\hline & $\mathbf{2 0 0 3}$ & $\mathbf{2 0 1 0}$ & $\mathbf{2 0 1 4}$ \\
\hline Universidades & 45 & 59 & 63 \\
\hline Campus/unidades & 148 & 274 & 321 \\
\hline $\begin{array}{l}\text { Municípios } \\
\text { Atendidos }\end{array}$ & 114 & 230 & 275 \\
\hline
\end{tabular}

Fonte: $\mathrm{SeSu} / \mathrm{Mec}$

A Expansão se deu também em relação ao número de cursos de graduação, presenciais, bem como número de matrículas. 


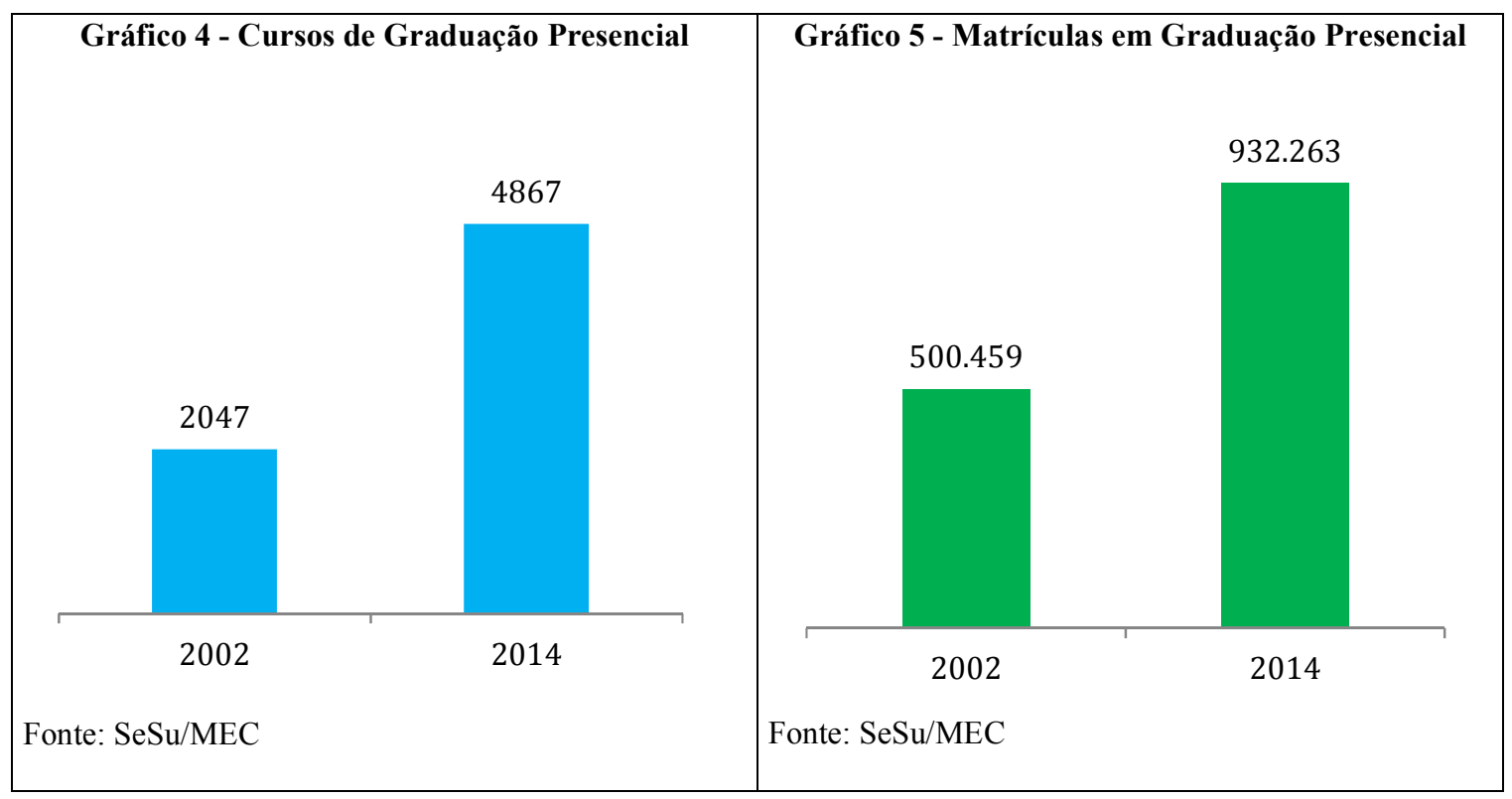

$\mathrm{Na}$ educação superior a distância, houve um considerável aumento nas matrículas onde em 2002 haviam 11.964 alunos matriculados passando para 83.605 novas matrículas no ano de 2014.

Quanto ao orçamento, em 2003, o Ministério da Educação (MEC) dispunha de 19,8 bilhões de Reais, destes, 6 bilhões eram destinados às Instituições Federais de Ensino. Em 2013, houve um aumento de mais de 80 bilhões no orçamento do MEC, totalizando 101,9 bilhões de reais dos quais, 40 bilhões foram destinados à educação superior.

\section{METODOLOGIA}

Foi realizada uma pesquisa exploratória complementada com dados referente ao Programa de Extensão: "Prevenção e reabilitação em idosos e adultos jovens cardiopatas ou não e sua inserção no esporte e ao Projeto "Saúde Integral em Famílias Carentes no Distrito Federal", além da coleta de dados apresentando os números de ingressantes e permanência dos cinco cursos da FCE, levantar valores de gastos do Governo Federal com o programa Reuni na UnB e, especificamente, na FCE, sabendo que este método:

Caracteriza-se pelo emprego de quantificação tanto nas modalidades de coleta, quanto no tratamento delas por meio de técnicas estatísticas, desde a mais simples como percentual [...](Richardson, 1999) 
No tocante a pesquisa exploratória, conforme Gil (2007) o objetivo é ter uma maior compreensão do problema, visando a construção de hipóteses, principalmente no que tange a entrevistas com pessoas e análise de exemplos.

Foi feito, em primeiro momento, uma reflexão geral sobre os Projetos/Programas de Extensão da FCE buscando apresentar números de beneficiários, atuação destes projetos na comunidade de Ceilândia e, num segundo momento, entrevistas com os partícipes (estudantes e comunidade beneficiária) do Projeto de Extensão: Saúde Integral: "Saúde Integral em Famílias Carentes do Distrito Federal e do Programa de Extensão "Prevenção e reabilitação em idosos e adultos jovens cardiopatas ou não e sua inserção no esporte”.

Para esta análise, foram utilizados dados extraídos do Sistema de Controle Acadêmico de Graduação (SIGRA), levando em consideração: a) número de discentes que ingressaram na FCE entre os anos de 2009 e 2015, b) do total de alunos, quais efetivamente são moradores da Ceilândia, e c) Análise de dados colhidos dos projetos de Extensão, em particular o projeto: Saúde Integral: "Observar, inserir e intervir: uma nova sensibilidade nas práticas de saúde" e o Programa "Prevenção e reabilitação em idosos e adultos jovens cardiopatas ou não e sua inserção no esporte".

A escolha das duas atividades se deu, a partir de duas realidades distintas. O Programa de Extensão: "Prevenção e reabilitação em idosos e adultos jovens cardiopatas ou não e sua inserção no esporte", por ser uma atividade que funciona no laboratório do próprio campi, e com atendimento individualizado, onde os beneficiários/pacientes tem consulta marcada, em três dias da semana.

Quanto ao Projeto “Saúde Integral em Famílias Carentes no Distrito Federal”, por se tratar de uma comunidade com muita vulnerabilidade social e a atuação é sobre a família, o que diferente do tratamento individualizado, busca, além da busca das necessidades comunitárias, com lideranças locais.

Desta forma, ao escolher estas duas atividades de extensão, busca-se evidenciar a importância da universidade desde a sua atuação indo "ao encontro" com a comunidade, no caso do Projeto "Saúde Integral em Famílias Carentes no Distrito Federal”, quando à 
comunidade indo à universidade, como o caso do programa Prevenção e reabilitação em idosos e adultos jovens cardiopatas ou não e sua inserção no esporte, estabelecendo uma relação de cooperação.

O questionário foi aplicado para catorze beneficiários do Programa de Extensão: "Prevenção e reabilitação em idosos e adultos jovens cardiopatas ou não e sua inserção no esporte", de um total de dezesseis participantes, no mês de agosto de 2016. Foram aplicados, ainda, vinte e um questionários aos participantes do projeto "Saúde Integral em Famílias Carentes no Distrito Federal", entre julho e agosto de 2016.

Adotamos nesta pesquisa, o conceito de democratização no acesso ao ensino superior, a partir da criação e expansão de vagas no ensino superior público e gratuito, onde os dados extraídos do Sistema de graduação (SIGRA) permitem refletir acerca do ingresso, permanência e conclusão dos discentes na Faculdade de Ceilândia (FCE) entre 2009e 2015, excluindo o curso de fonoaudiologia, por se tratar de um curso iniciado no segundo semestre de 2013, o que impede em fazer uma análise mais acurada, tendo em vista que não houve a conclusão de um ciclo (ingresso, permanência e conclusão).

\section{$\underline{\text { Instrumentos e Materiais }}$}

A realização da pesquisa se deu a partir do levantamento de dados, impressos para a aplicação de questionários aos participantes e que se encontra no Anexo, além de análise da Proposta dos Programa/Projetos de Extensão. 


\section{ANÁLISE DE DADOS}

\subsection{UnB: da Fundação à expansão}

$\mathrm{Na}$ inauguração de Brasília, o chefe do poder executivo federal, o presidente Juscelino Kubitscheck de Oliveira (JK), em seu primeiro ato na nova capital do país apresenta ao Congresso Nacional o Projeto de Lei $n^{0}$ 1.861/60, com a proposta de criação da Fundação Universidade de Brasília (FUB), e que efetivamente foi inaugurada em 21 de abril de 1962.

Porém as aulas já haviam iniciado em 9 de abril de 1962, contando com 413 alunos de graduação e pós-graduação, após processo seletivo (vestibular) para 830 candidatos. Somente em 1963 inicia a construção do Instituto Central de Ciências (ICC) projetado por Oscar Niemeyer, sendo a principal edificação da UnB e que será concluída em 1971.

Os objetivos iniciais da $\mathrm{UnB}^{11}$, segundo seu projeto são:

- Ampliar as exíguas oportunidades de educação oferecidas à juventude brasileira

- Diversificar as modalidades de formação cientifica e tecnológica atualmente ministradas, instituindo as novas orientações técnico profissionais que incremento da produção, a expansão dos serviços e das atividades intelectuais estão a exigir.

- Contribuir para que Brasília exerça, efetivamente, a função integradora que se propõe assumir, pela criação de um núcleo de ensino superior aberto aos jovens de todo o país e a uma parcela da juventude da América Latina e de um centro de pesquisa cientifica e de estudos de alto padrão.

- Assegurar a Brasília a categoria intelectual que ela precisa ter como capital do país e torna-la, prontamente, capaz de imprimir caráter renovador aos empreendimentos que deverá projetar e executar.

- Garantir à nova capital a capacidade de interagir com os nossos principais centros culturais, para ensejar o pleno desenvolvimento das ciências, das letras e das artes em todo o Brasil.

- Facilitar aos poderes públicos o assessoramento de que carecem em todos os ramos do saber, o que somente uma universidade pode prover.

- Dar à população de Brasília perspectiva cultural que a liberte do grave risco de fazer-se medíocre e provinciana, no cenário urbanístico e arquitetônico mais moderno do mundo. (DARCY RIBEIRO, 1961)

A UnB surge num cenário de mudança da capital do país e prima pela inovação tecnológica, oportunidades de acesso à educação superior aos jovens, excelência em pesquisas, proposição de inovações, entre outros, sendo um espaço para propostas modernas ao Brasil.

\footnotetext{
${ }^{11} \mathrm{http}: / /$ www.bvanisioteixeira.ufba.br/artigos/unbdarci.html<acesso em 7 de agosto de 2016
} 
Porém, alguns fatos marcam o Início da $\mathrm{UnB}^{12}$, principalmente a partir do governo Militar, no final da década de 1960 e início da década de 1970, onde episódios de truculência e sucessivas invasões, revistas à comunidade acadêmica, interdição de departamentos e salas de professores, demissão de docentes, tais como Anísio Teixeira e Almir Castro, e nomeação de reitor com alinhamento ao governo.

Ao longo dos anos, a UnB expandiu o número de cursos, possuindo atualmente 80 cursos de graduação, sem contar a pós-graduação.

Gráfico 6 - Evolução do número de cursos da UnB

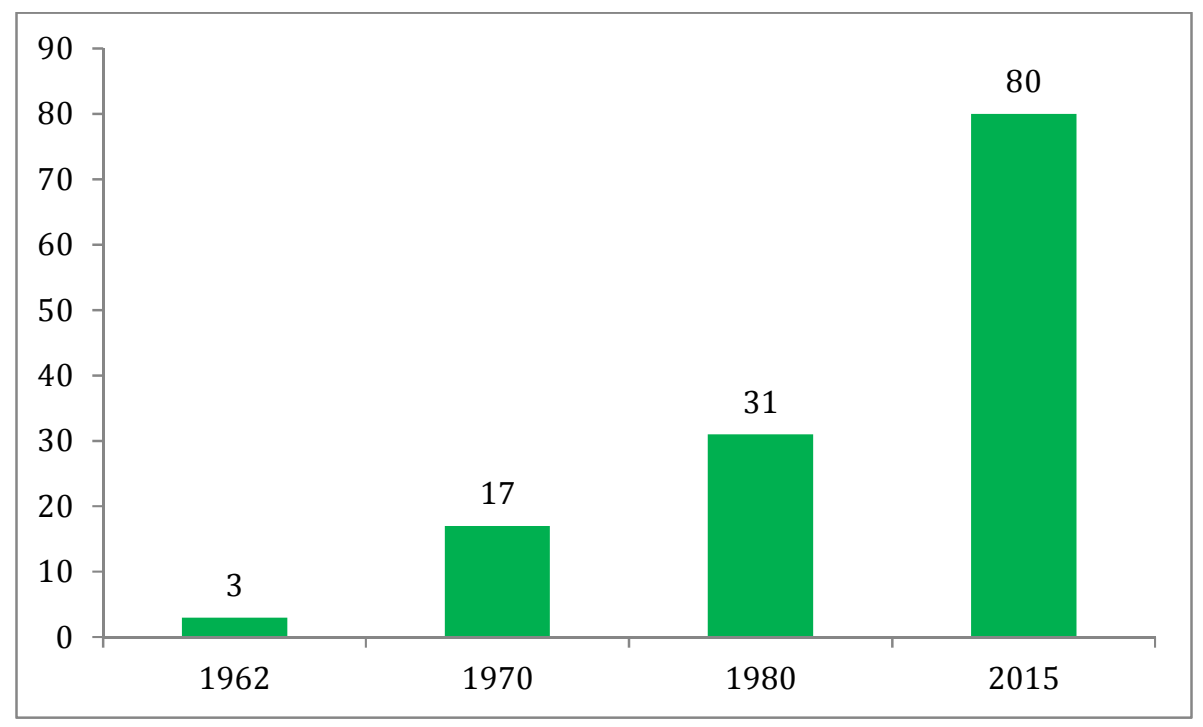

Fonte: Elaborado pelo autor

Vários cursos tiveram expansão, a partir do Reuni, como por exemplo o curso de Enfermagem da Faculdade de Ceilândia criado em 2008 e já existente no campus Darcy Ribeiro. Destes 80 cursos há, 6 na FGA, 6 na FCE, 4 na FUP, 9 pela Universidade Aberta do Brasil (UAB) e 55 no Darcy Ribeiro.

Quanto à evolução do número de matrículas a UnB expandiu, ao longo de meia década:

\footnotetext{
${ }^{12} \mathrm{http}: / /$ www.unb.br/sobre/principais_capitulos/invasoes> acesso em 4 de agosto de 2016.
} 


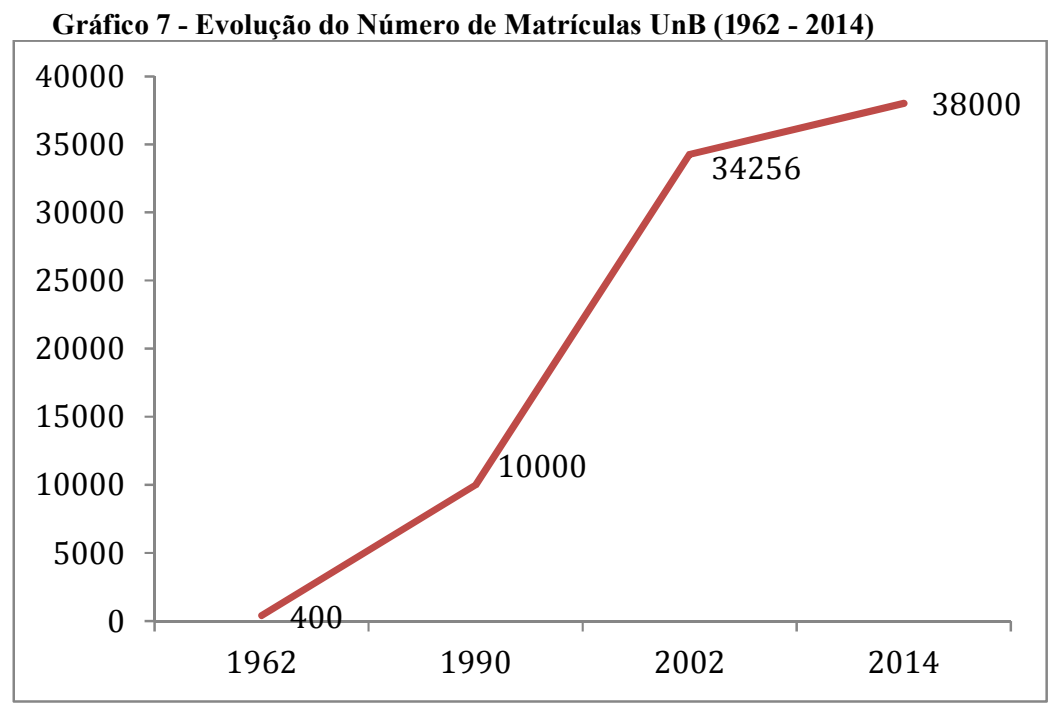

Fonte: UnB

A universidade de Brasília (UnB) adere ao Reuni a partir da $333^{\text {a }}$ Reunião do Conselho universitário da UnB (CONSUNI), realizada em 19 de outubro de 2007, apresentando o documento A UnB Rumo aos 50 anos: Autonomia, Qualidade e Compromisso Social, para pleitear o ingresso ao Reuni ${ }^{13}$.

A partir de 2001, buscou-se, na UnB, a reinvenção do processo de planejamento institucional, sob a coordenação da Secretaria de Planejamento (SPL) da universidade, e pautados nos objetivos de "envolver a comunidade universitária no planejamento institucional e desenvolver uma metodologia de trabalho adequada às características, à cultura e à estrutura da Universidade" que resultou na elaboração do Plano de Desenvolvimento Institucional $(2002-2006)^{14}$.

Entre as metas do PDI, havia a previsão de expansão da universidade para outras três cidades do Distrito Federal: Ceilândia, Gama e Planaltina. Nisso, a UnB realiza a sua primeira expansão para a cidade de Planaltina, e que inicia suas atividades em março de 2006, realizando a missão de implantação de cursos comprometidos com o desenvolvimento Regional.

\footnotetext{
${ }^{13}$ Plano de Reestruturação e Expansão da Universidade de Brasília

${ }^{14}$ Fundação Universidade de Brasília, Plano de desenvolvimento institucional / Nair Aguiar Miranda (organizadora)._Brasília, 2005.
} 
Destacar este histórico faz-se necessário para uma compreensão da expansão da UnB, antes, no caso de Planaltina, e depois, Ceilândia e Gama, da adesão da UnB ao Reuni.

A primeira versão do projeto de adesão da UnB ao Reuni foi enviada ao Ministério da Educação (MEC) e aprovada no ano de 2007. Porém, o projeto teve que voltar para a UnB por uma série de contradições e sem a participação da comunidade acadêmica.

Um primeiro ponto levantado acerca dos problemas envolvidos na primeira versão do projeto está contido no documento Plano de Reestruturação e Expansão da Universidade de Brasília 2008-2012, onde:

i) O projeto específico submetido ao MEC em 29 de outubro de 2007 não havia sido aprovado pelo Conselho Universitário [...]; (FUB, 2008).

Entre outros pontos contraditórios, listados no Plano podemos destacar:

iii) [...] dos 27 cursos novos propostos pelas Unidades Acadêmicas e constantes do documento "A UnB Rumo aos 50 anos: Autonomia, Qualidade e Compromisso Social", apenas 10 haviam sido incluídos na proposta final encaminhada ao MEC, $[\ldots]$;

vi) [...]UnB continha equívocos nos dados de pós-graduação [...];

vii) $[. .$.$] continha equívocos na duração de alguns cursos de graduação [...];$

viii) [...] continha dados de número de egressos de alguns cursos de graduação mais elevados do que os dados oficiais da UnB demonstravam [...];

ix) [...] o TCU, em 16 de abril de 2008, havia determinado a devolução aos cofres da União de $\mathrm{R} \$ 30.742 .529,30$, referentes à parcela de rubrica investimentos estabelecida para 2007 no âmbito do REUNI [...]; e

$\mathrm{x})$ havia um sentimento de necessidade de maiores discussões sobre o REUNI por parte da maioria da comunidade acadêmica. (FUB, 2008)

Finalmente, o documento para a adesão da UnB ao Reuni foi aprovado em 26 de junho de 2008, pelo Conselho de Ensino, Pesquisa e Extensão (CEPE):

Os resultados do trabalho da Comissão no que se refere à lista de cursos novos e de ampliação de vagas nos cursos existentes e à estimativa de distribuição de docentes e de recursos financeiros, elaborados com base nas demandas das Unidades Acadêmicas, nos trabalhos realizados pelas Comissões, nas discussões ocorridas no Seminário e no próprio CEPE, no documento Diretrizes para adequação da proposta da UnB às Diretrizes Gerais do REUNI e nas Metas e Diretrizes Gerais do REUNI. (FUB, 2008)

Após aprovação do CEPE, o documento foi objeto de discussão e deliberação da $339^{a}$ reunião do CONSUNI, em 4 de julho de 2008, apresentando as metas gerais e as estratégias para o alcance destas: 
Criação de novos cursos e expansão dos já existentes, sobretudo no período noturno, como forma de melhorar o aproveitamento do espaço físico, Abertura de novos cursos com perfis interdisciplinares - parcerias entre diferentes unidades acadêmicas, Reestruturação pedagógica, criação de mobilidade inter e intrainstitucional, criação de políticas de fortalecimento institucional, redução da evasão, ampliação da inclusão social e fortalecimento das licenciaturas. (MEC, 2008)

Com a adesão ao Reuni, a UnB, principalmente no que tange à Criação de novos cursos e expansão dos já existentes, assegurou a criação de 480 vagas anuais em cinco cursos específicos para o campi da UnB na Ceilândia, a Faculdade de Ceilândia (FCE), na área de saúde, ampliando para a unidade na cidade de Ceilândia os cursos de Enfermagem e Farmácia, bem como a criação de novos cursos de Fisioterapia, Terapia Ocupacional e Saúde Coletiva.

\subsection{A Região Administrativa de Ceilândia}

A História de Ceilândia, que está relacionada com a exclusão social e o imaginário de uma localidade de periferia, foi criada a partir de uma ação política coordenada pela primeira-dama, a Sra. Vera de Almeida Silveira, esposa do governador biônico Hélio Prates da Silveira ${ }^{15}$.

No ano de 1969, segundo dados divulgados no portal da Administração de Ceilândia, já existiam cerca de 80 mil pessoas que moravam em favelas no entorno de Brasília: Vila IAPI, Tenório, Esperança, Bernardo Sayão, Colombo, morro do Querosene, do Urubu, Curral das Éguas e Placa das Mercedes.

A necessidade em deslocar estas pessoas, fez com que o Governo criasse a Campanha de Erradicação de Invasões (CEI), para promover a remoção dos moradores das favelas para uma das extremidades de Brasília, a fazenda guariroba, pertencente à cidade de Luziânia - GO (atual localização da Ceilândia).

Esta comissão era presidida pela primeira Dama Vera de Almeida Silveira. A palavra inglesa land que traduzido significa terra, muito comum na formação de nomes de cidades foi adicionado à sigla da Campanha de Erradicação de Invasões (CEI) dando nome à cidade que iria abrigar os moradores das favelas.

\footnotetext{
${ }^{15}$ O Governador do Distrito Federal foi um cargo de indicação do Presidente da República desde a sua fundação até o ano de 1990, onde ocorreu a primeira eleição direta..
} 
O cineasta Adirley Queirós (2014) expõe em seu filme Branco sai, Preto fica, as relações de poder do centro versus periferia tendo como ponto de partida a Ceilândia, onde a exclusão marca o cotidiano da capital frente às periferias.

Ceilândia atualmente possui 489.351 mil habitantes, segundo dados da Pesquisa Distrital por Amostra de Domicílios (PDAD). Seu crescimento está associado, entre outros fatores, à ocupação desordenada de terras, formando comunidades como o Setor habitacional Sol Nascente, localidade sem a devida urbanização.

Em 2008, a Ceilândia recebe a primeira Instituição de Ensino Superior Pública, a Faculdade de Ceilândia (FCE) da Universidade de Brasília. A missão institucional a UnB na Ceilândia tem trabalhado em conformidade com as suas diretrizes na indissociabilidade do Ensino da Pesquisa e da Extensão dando retorno à comunidade local, objeto principal desta pesquisa.

\subsection{A Faculdade de Ceilândia (FCE)}

A expansão da Universidade de Brasília (UnB), já prevista no Plano de Desenvolvimento Institucional do ano de 2002 a 2006, para as Regiões Administrativas de Ceilândia, Gama e Planaltina, sendo que:

[...] oferecerão, quando concluídos, até 600 novas vagas por ano, beneficiando uma população de 2,9 milhões de pessoas residentes na Região Integrada de Desenvolvimento do Distrito Federal (RIDE), da qual fazem parte o Distrito Federal e municípios dos Estados de Goiás e de Minas Gerais. (FUB, 2005).

Um marco importante para a expansão da UnB para a Região Administrativa de Ceilândia é o lançamento da pedra fundamental em 13 de outubro de 2006, com a participação da governadora do Distrito Federal (DF), Maria de Lourdes Abadia, com o ministro da Educação, Fernando Haddad, com o reitor da UnB, Timothy Mulhohand, entre outras autoridades.

Entre as justificativas ${ }^{16}$ apontadas para a expansão para a região de Ceilândia estão:

a) Maior concentração populacional do DF (18\%);

b) Está entre as menores rendas percapitas da região;

\footnotetext{
${ }^{16}$ Disponível no Plano de Expansão da UnB (2005)
} 
c) Área de influência à outras regiões do entorno;

d) Estratégia para o desenvolvimento regional

Em princípio, devido à baixa escolarização da população local, onde, segundo dados apontados em reportagem do portal do MEC, no ano de 2006, apenas $12,5 \%$ da população da Ceilândia possuía o segundo grau completo, e menos de $1 \%$ concluíram o ensino superior ${ }^{17}$.

A inclusão dos cursos é na área de saúde, devido ao diagnóstico (2008) apresentado pela comissão coordenada pela Diretora da FCE, onde apresenta oportunidades no desenvolvimento de projetos de extensão para a comunidade local, o que beneficiaria tanto a população local, carente de políticas públicas para a saúde, visando fornecer futuros quadros técnicos para a saúde local, bem como ao atendimento de movimentos sociais, como o MOPUC, na oferta de ensino superior público, gratuito e de qualidade. (FCE, 2008).

O Ato da Reitoria $\mathrm{n}^{\circ}$ 789, do dia 16 de maio de 2007 dispõe sobre a criação da Unidade Acadêmica de Ceilândia, regida pelo Estatuto e pelo Regimento Geral da Universidade de Brasília (FUB, 2007).

A abertura para a participação da comunidade no Conselho Universitário (Consuni), no dia 9 de maio de 2008, marca a disponibilidade de a comunidade acadêmica ouvir a sociedade civil, os movimentos sociais, onde os diversos representantes das mais variadas cidades, entre elas, Ceilândia, puderam expor suas pautas e serem ouvidas pelos representantes dos professores, servidores e alunos da $\mathrm{UnB}^{18}$.

O primeiro vestibular da Universidade de Brasília com vagas para Ceilândia foi realizado nos dias 26 e 27 de julho de 2008, onde a previsão de 240 vagas se confirma e, nesta primeira seleção, são matriculados 241 discentes, nos cursos de Farmácia, Enfermagem, Gestão de Saúde (Saúde Coletiva), Terapia Ocupacional e Fisioterapia ${ }^{19}$.

Em 2008, é apresentado o documento "Implantação e Consolidação do Núcleo Multidisciplinar de Formação de Profissionais na Área de Saúde na Faculdade UnB Ceilândia, no âmbito do Ensino, Pesquisa e Extensão", com duração prevista para 48 meses, entre outubro de 2008 e setembro de 2012, tendo como objetivo:

\footnotetext{
${ }^{17}$ http://portal.mec.gov.br/ultimas-noticias/212-educacao-superior-1690610854/7040 $1792736085 \&$ gws $\mathrm{rd}=$ cr\&ei=7RSzV9ZYgseZAb3mvDg acesso em 6 de agosto de 2016.

${ }^{18} \mathrm{http}: / /$ www.unb.br/noticias/print_email/imprimir.php?u=http://www.unb.br/noticias/unbagencia/unbagencia.php?id=226 acesso em $6 \mathrm{de}$ agosto de 2016.

${ }^{19}$ Do primeiro Vestibular, em julho de 2008
} 
[...] dar condições para implantar, consolidar e dar sustentabilidade ao núcleo multidisciplinar de formação de profissionais na área de saúde no campus Ceilândia da Universidade de Brasília. (FCE, 2008)

O documento faz referência aos dados e indicadores de 2008 onde indica que 16,7\% da população do DF mora na Ceilândia, que encontra-se em expansão. Nisto, apresenta a principal meta FCE:

Oferecer o acesso à educação superior nas Ceilândia e suas áreas de influência (Taguatinga, Brazlândia, Gama, Recanto das Emas, Riacho Fundo I e II, Samambaia). (FCE, 2008).

Uma parceria importante para a implantação da FCE foi o acordo com o Governo do Distrito Federal (GDF) com a cessão de espaço do Centro de Ensino Médio 4 ocorrida no dia 9 de julho de 2008, um ano e meio depois do lançamento da pedra fundamental do futuro campi de Ceilândia, onde a previsão de ocupação do espaço seria por dois semestres letivos sendo devolvido ao final do primeiro semestre de $2009^{20}$.

A Adesão da UnB ao Reuni proporciona a expansão para a Ceilândia, a maior Região Administrativa e população do Distrito Federal (DF) dando início as suas atividades no segundo ${ }^{21}$ semestre de 2008 com os cursos na área de saúde: Enfermagem, Farmácia, Fisioterapia, Gestão de Saúde (Saúde Coletiva) e Terapia Ocupacional ${ }^{22}$.

A FCE atuou provisoriamente, no Núcleo de Práticas Jurídicas (NPJ) da Faculdade de Direito situada na Ceilândia, próximo ao próximo à unidade da Empresa Brasileira de Correios e Telégrafos (EBCT). Segundo relato do servidor da FUB:

As aulas iniciaram ainda em agosto no NPJ e havia apenas duas salas de aula. Elas funcionavam no período matutino e vespertino, sempre lotadas e sem qualquer tipo de conforto.

Não havia biblioteca, centro acadêmico, laboratório. Os professores tinham que se virar em uma sala improvisada com duas mesas para planejar suas aulas.

\footnotetext{
${ }^{20} \mathrm{http}: / /$ soudeceilandia.blogspot.com.br/2008/07/espao-da-unb-em-ceilndia-garantido.html

${ }^{21}$ A Ata de reunião referente Pactuação do Programa de Expansão Etapa I - Campus de Ceilândia -Universidade Federal de Brasília - UnB previa o início das atividades na FCE no primeiro semestre de 2008, porém, os vários problemas na condução do documento, principalmente referente a falta de participação da comunidade acadêmica e posterior retorno do projeto para a UnB adiou para o segundo semestre de 2008 o início das atividades na unidade de Ceilândia.

${ }^{22}$ www.fce.unb.br acesso em 6 de agosto de 2016.
} 
Vários contratempos aconteceram, desde a instalação provisória no Núcleo de Práticas Jurídicas (NPJ), a transferência acadêmica e administrativa para o CEM 4 e, finalmente a instalação no campi definitivo, este último, por mais de quatro anos por se entregue.

Em 02 de julho de 2008 ocorre a solenidade de posse da Diretoria do novo campi, com a presença do Reitor pro tempore Roberto Aguiar, o vice-reitor José Carlos, a Diretora da FCE, Diana Lúcia Moura Pinho, Ana Carolina Acevedo Poppe, Vice-Diretora, além dos coordenadores dos cursos de Gestão de Saúde (Saúde Coletiva), Farmácia, Enfermagem, e outros convidados da Faculdade de Saúde (FS) e Medicina da Universidade de Brasília ${ }^{23}$ (FCE, 2009).

O processo de Expansão da UnB para a Ceilândia se dá em 4 fases:

a) Uso das Instalações da Faculdade de Saúde - Campus Darcy Ribeiro:

b) Uso das Instalações do Núcleo de Práticas Jurídicas da Faculdade de Direito em Ceilândia;

c) Uso de Parte das Instalações do Centro de Ensino Médio 4 de Ceilândia;

d) Ocupação do Campi definitivo. (FCE, 2009)

A primeira fase constituiu de trabalhos administrativos como compras de material, licitação, entre outros sendo também o local da primeira e segunda reunião do Conselho Pleno $^{24}$ da FCE. A Segunda fase, se dá a partir do atraso nas obras do CEM 4, evitando, assim, prejuízos ao semestre letivo, que já estava por acontecer.

A partir dessa situação, o Decanato de Ensino e Graduação (DEG) em conjunto com a Prefeitura (PRC) buscou espaço físico como alternativa para superar o atraso da adequação do CEM 4. Com essa necessidade premente, lançou mão das instalações no Núcleo de Práticas Jurídicas (NPJ) que a universidade mantém em Ceilândia, no intuito de evitar o comprometimento do início das aulas do período de 2008/2. (FCE, 2009).

${ }^{23}$ Relatório de Gestão Campus Ceilândia - Ano 12009.

${ }^{24}$ As Unidades Acadêmicas têm como órgão máximo deliberativo e de recurso, em matéria administrativa e acadêmica, o Conselho de Instituto ou de Faculdade e, como órgão executivo, a Direção. (FUB, 2011). 
Em 14 de outubro de 2008, foram entregues as chaves do Centro de Ensino Médio para a direção da $\mathrm{FCE}^{25}$, o que significou a mudança para o campi provisório, começando as as aulas nesse local desde novembro ${ }^{26}$.

$\mathrm{Na}$ tentativa de mostrar o processo de criação do Campi e os entraves apresentados durante o mesmo foram analisadas as principais notícias do portal da Secretaria de Comunicação (SECOM) da Universidade de Brasília, bem como outros veículos de comunicação onde descrevem a tensão entre a criação do campi definitivo da FCE, sua estrutura provisória, até a sua entrega definitiva.

Tabela 2 - Criação do Campi definitivo da FCE

\begin{tabular}{|c|c|c|}
\hline Data & Título & $\begin{array}{l}\text { Veículo de } \\
\text { Comunicação }\end{array}$ \\
\hline $15 / 10 / 2009$ & $\begin{array}{l}\text { Ministério Público pede relatório técnico ambiental do novo campus da } \\
\text { Ceilândia }\end{array}$ & UnB-Agência \\
\hline $09 / 11 / 2009$ & $\begin{array}{l}\text { Novos campi da Ceilândia e do Gama não ficarão prontos para o } \\
\text { próximo semestre }\end{array}$ & UnB-Agência \\
\hline $12 / 11 / 2009$ & Alunos da UnB estudam em campus provisório & DFTV \\
\hline $12 / 01 / 2010$ & Obras nos campi Ceilândia e Gama estão a todo vapor & UnB-Agência \\
\hline $02 / 02 / 2010$ & UnB terá mais duas salas e um auditório para o $1^{\circ}$ de 2010 & UnB-Agência \\
\hline $11 / 03 / 2010$ & Reitor cobra do GDF conclusão de obras nos campi & UnB-Agência \\
\hline $28 / 06 / 2010$ & Crise no GDF atrasa novo campus de Ceilândia & UnB-Agência \\
\hline $06 / 07 / 2010$ & $\begin{array}{l}\text { Estudantes da UnB, Campus da Ceilândia, reclamam das condições de } \\
\text { ensino. }\end{array}$ & Campus \\
\hline $15 / 07 / 2010$ & Faculdade de Ceilândia será entregue em 120 dias & UnB-Agência \\
\hline $16 / 07 / 2010$ & Campus está em fase final & $\begin{array}{l}\text { Jornal de } \\
\text { Brasília }\end{array}$ \\
\hline $02 / 08 / 2010$ & Obra da UnB Ceilândia sofre com número reduzido de operários & UnB-Agência \\
\hline $20 / 09 / 2010$ & $\begin{array}{l}\text { Governador do DF quer entregar obre da UnB Ceilândia em } 1^{\circ} \text { de } \\
\text { dezembro }\end{array}$ & UnB-Agência \\
\hline $25 / 11 / 2010$ & Comunidade de Ceilândia protesta contra atraso nas obras do campus & UnB-Agência \\
\hline $13 / 12 / 2010$ & Campus UnB Ceilândia será inaugurado à base de geradores & UnB-Agência \\
\hline $14 / 12 / 2010$ & Campus da UnB em Ceilândia será inaugurado apenas em 2011 & $\begin{array}{c}\text { Correio } \\
\text { Braziliense }\end{array}$ \\
\hline $14 / 12 / 2010$ & Funcionamento com gerador & $\begin{array}{c}\text { Jornal de } \\
\text { Brasília }\end{array}$ \\
\hline $03 / 01 / 2011$ & Laboratórios começam a ser montados em 15 dias & UnB-Agência \\
\hline $20 / 01 / 2011$ & Bloco do campus será entregue em março & $\begin{array}{l}\text { Tribuna do } \\
\text { Brasil }\end{array}$ \\
\hline $25 / 01 / 2011$ & Reitor visita UnB Ceilândia para garantir início das aulas em 2011 & UnB-Agência \\
\hline $22 / 02 / 2011$ & Atraso nas obras do prédio da Ceilândia preocupa Administração & UnB-Agência \\
\hline $23 / 02 / 2011$ & Reitor vai conversar com Agnelo sobre campus da Ceilândia & UnB-Agência \\
\hline $01 / 03 / 2011$ & Novacap vai multar construtora em caso de atraso na UnB Ceilândia & UnB-Agência \\
\hline $11 / 03 / 2011$ & UnB e Ibram assinam licença de instalação dos novos campi & UnB-Agência \\
\hline $15 / 03 / 2011$ & UnB Ceilândia: obra só será entregue em abril & UnB-Agência \\
\hline $23 / 03 / 2011$ & Estudantes visitam obras dos novos campi & UnB-Agência \\
\hline
\end{tabular}

${ }^{25}$ Ata da $9^{\text {a }}$ Reunião do Conselho Pleno da FCE.

${ }^{26}$ Ata da $12^{\mathrm{a}}$ Reunião do Conselho Pleno da FCE. 


\begin{tabular}{|l|l|l|}
\hline $25 / 03 / 2011$ & UnB Ceilândia começa a montar laboratórios na semana que vem. & UnB-Agência \\
\hline $31 / 03 / 2011$ & Novos campi: três anos de expectativas. & UnB-Agência \\
\hline $01 / 04 / 2011$ & Alunos pedem ao GDF solução para atraso nas obras & UnB-Agência \\
\hline $18 / 04 / 2011$ & Primeiro Prédio da UnB Ceilândia será entregue parcialmente no dia 30 & UnB-Agência \\
\hline $27 / 05 / 2011$ & Secretário de Obras dá ultimato à construtora da UnB Ceilândia & UnB-Agência \\
\hline $22 / 06 / 2011$ & Reitor visita UnB Ceilândia na segunda-feira & UnB-Agência \\
\hline $28 / 06 / 2011$ & Construtora entrega primeiro prédio da UnB Ceilândia à Novacap. & UnB-Agência \\
\hline $30 / 06 / 2011$ & Deputados distritais visitam obras do campus de Ceilândia & UnB-Agência \\
\hline $08 / 07 / 2011$ & Novos campi terão novas instalações no próximo semestre & UnB-Agência \\
\hline $27 / 07 / 2011$ & Novacap quer rescindir contrato com construtora da UnB Ceilândia. & UnB-Agência \\
\hline $04 / 08 / 2011$ & Contagem regressiva para inauguração do campus de Ceilândia & UnB-Agência \\
\hline $15 / 09 / 2011$ & Estudantes de Ceilândia protestam em audiência com senadores. & UnB-Agência \\
\hline $21 / 09 / 2011$ & Professores propõem adiar semestre e manter vestibular & UnB-Agência \\
\hline $21 / 09 / 2011$ & Alunos de Ceilândia vão defender suspensão do vestibular no Consuni. & UnB-Agência \\
\hline $23 / 09 / 2011$ & Conselheiros discutem suspensão do vestibular de Ceilândia. & UnB-Agência \\
\hline $26 / 09 / 2011$ & GDF rompe contrato com a UniEngenharia. & UnB-Agência \\
\hline $29 / 09 / 2011$ & Reitor e ADUnB debatem soluções para o campus Ceilândia. & UnB-Agência \\
\hline $11 / 10 / 2011$ & GDF promete para semana que vem repasse de prédio do campus & UnB-Agência \\
& Ceilândia à UnB. & \\
\hline $21 / 10 / 2011$ & Ministério Público Federal vai monitorar obras da UnB Ceilândia. & UnB-Agência \\
\hline $30 / 11 / 2011$ & UnB assume obra no campus Ceilândia. & UnB-Agência \\
\hline
\end{tabular}

Fonte: UnB/Secom

Após este imbróglio que perdurou por quase cinco anos, um dos prédios, onde funciona a administração e laboratórios foi entregue no segundo semestre de 2012 , e a Unidade Acadêmica, entregue no primeiro semestre de 2013. A entrega oficial dos prédios se deu em abril de 2014, em solenidade no auditório da Unidade Acadêmica (UAC).

Atualmente, a FCE conta com três edifícios em seu espaço definitivo: Unidade de Ensino e Docência (UAD), Unidade Acadêmica (UAC) e o Módulo de Serviços e Equipamentos Esportivos (MESP), além do espaço do Centro de Ensino Médio 4.

A UED conta com os seguintes espaços: setor de contabilidade, setor de compras, administração predial e patrimonial, gestão de pessoas, direção, sala de reuniões, seis salas de coordenação dos cursos de graduação, secretaria de graduação, secretaria de pós-graduação, sala da coordenação de pós-graduação, sala de alunos da pós-graduação, copa, quarenta salas de professores, oito laboratórios, almoxarifado, sala do comitê de ética, sala dos motoristas, sala da segurança e um auditório com capacidade de cem pessoas e uma lanchonete, dois vestiários.

A UAC conta com dezesseis salas de aulas, secretaria acadêmica, apoio didático, serviço de orientação ao universitário, biblioteca, oito laboratórios, incluindo dois de informática, um auditório com capacidade para 200 pessoas e uma lanchonete. 
O MESP conta com o restaurante universitário, serviço de xerox, seis centros acadêmicos e uma quadra poliesportiva.

O CEM 4 conta com cinco laboratórios, nove salas de aula, secretaria do UnB idiomas, copa e lanchonete.

A equipe de servidores da Faculdade de Ceilândia é composta por 65 TécnicosAdministrativos em Educação (TAE) e 153 docentes.

\subsection{Análise das metas: Criação de novos cursos, com perfis interdisciplinares - e redução da evasão na FCE.}

A Expansão da UnB para a Região Administrativa de Ceilândia, embora previsto no Plano de Desenvolvimento Institucional de 2002 a 2006, efetivamente, só ocorreu no ano de 2008, a partir da adesão ao Programa de Apoio a Planos de Reestruturação e Expansão das Universidades Federais. Este capítulo explorará os documentos oficiais (Atas, Relatórios, entre outros), trabalhos acadêmicos que indiquem o cumprimento das metas, bem como projetos político pedagógicos, especificamente na Faculdade de Ceilândia.

\subsection{Criação de novos cursos e expansão dos já existentes, sobretudo no período noturno, como forma de melhorar o aproveitamento do espaço físico.}

Por se tratar de um campus novo, esta primeira meta é atingida parcialmente. Se por um lado houve a criação de quatro novos cursos: Saúde Coletiva, Terapia Ocupacional, Fisioterapia e Fonoaudiologia, e a expansão de dois cursos da Faculdade de Saúde: Enfermagem e Farmácia, por outro lado, não foi cumprido o quesito da criação de cursos no período noturno.

Os seis cursos inserem-se no:

[..] Programa de Apoio a Planos de Reestruturação e Expansão das Universidades Federais - REUNI, criado pelo Decreto Presidencial no 6096, de 24 de abril de 2007, juntamente com os Cursos de Enfermagem, Farmácia, Fisioterapia e Terapia Ocupacional implantados na Faculdade de Ceilândia da Universidade de Brasília. (PPP, 2009) 
Gestão de Saúde (Saúde Coletiva): curso que teve início no segundo semestre de 2008, e tem por objetivos formar profissionais com competências e habilidades para participar ativamente do processo de gestão das políticas de saúde em nível local, regional e central; estruturar, implantar e organizar a rede de atenção à saúde; colaborar com o setor de regulação; atuar nas organizações da sociedade civil ${ }^{27}$. Em 2010, houve a criação do curso de gestão em Saúde coletiva no campus Darcy Ribeiro.

Terapia Ocupacional: curso que teve início no segundo semestre de 2008, e tem por objetivos dotar o profissional dos conhecimentos requeridos para o exercício das seguintes competências e habilidades gerais para: (1) desenvolver ações de promoção, prevenção e reabilitação da saúde individual e coletiva; (2) assegurar que sua prática profissional seja realizada deforma integrada e contínua com as demais instâncias do sistema de saúde; (3) pensar criticamente, analisar problemas e procurar soluções dentro dos mais altos padrões de qualidade e dos princípios éticos; (4) avaliar, sistematizar e decidir condutas baseadas em evidências científicas; (5) dominar o uso de tecnologias de comunicação e informação; (6) atuar multiprofissionalmente em ações interdisciplinares, podendo assumir posições de liderança com compromisso, responsabilidade e habilidade para a tomada de decisões, comunicação e gerenciamento e (7) aprender continuamente, tanto na sua formação quanto na sua prática profissional ${ }^{28}$.

Fisioterapia: curso que teve início no segundo semestre de 2008, e tem por objetivos formar fisioterapeutas com competências para participar ativamente em todos os níveis de atenção à saúde desenvolvendo ações de promoção, prevenção, proteção e reabilitação coletiva e individual nas diferentes fases do ciclo da vida humana; tomar decisões com base em informações sistematizadas das situações de saúde para planejar, avaliar e decidir a implementação de ações baseadas em evidências; assumir posições de liderança, trabalhar em equipe, fazer a gestão da força de trabalho e dos meios necessários, visando o bem estar dos indivíduos e da coletividade e ser capaz de aprender continuamente, tanto na sua formação quanto na sua prática profissional, mantendo-se atualizado quanto às inovações científicas, tecnológicas e de informações ${ }^{29}$.

\footnotetext{
${ }^{27}$ Projeto Político Pedagógico do curso de Saúde Coletiva.

${ }^{28}$ Projeto Político Pedagógico do curso de Terapia Ocupacional.

${ }^{29}$ Projeto Político Pedagógico do curso de Fisioterapia.
} 
Fonoaudiologia: curso que teve início no segundo semestre de 2013, e tem por objetivos atuar na promoção, prevenção, aprimoramento e reabilitação da comunicação humana, bem como das funções neurovegetativas ${ }^{30}$.

Farmácia: Curso que teve sua expansão da Faculdade de Saúde e teve início no segundo semestre de 2008, tendo por objetivos formar profissionais que participem ativamente em todos os níveis de atenção à Saúde no que refere a ações de promoção, prevenção, proteção tanto no âmbito coletivo quanto no individual, nas diferentes fases do ciclo vital, tomem decisões com base em informações sistematizadas das situações de Saúde para planejar, avaliar e decidir a implementação de ações mais adequadas baseadas em evidências, assumam posições de liderança, trabalhar em equipe, fazer a gestão da força de trabalho e dos meios necessários visando o bem estar dos indivíduos e da coletividade. Sejam capazes de aprender continuamente, tanto na sua formação quanto na sua prática profissional, mantendo-se atualizado quanto às inovações científicas, tecnológicas e de informações ${ }^{31}$.

Enfermagem: curso que teve início no segundo semestre de 2008, e tem por objetivos formar o profissional enfermeiro com competências e habilidades gerais para(a) estar aptos a desenvolver ações de prevenção, promoção, proteção e reabilitação da saúde, tanto em nível individual quanto coletivo;(b) assegurar que sua prática seja realizada de forma integrada e continua comas demais instâncias do sistema de saúde;(c) realizar seus serviços dentro dos mais altos padrões de qualidade e dos princípios da ética/bioética, considerando que a responsabilidade da atenção à saúde não se encerra com o ato técnico, mas sim, com a resolução do problema de saúde, tanto a nível individual como coletivo ${ }^{32}$.

\subsection{Abertura de novos cursos com perfis interdisciplinares - parcerias entre diferentes unidades acadêmicas}

Esta meta também foi cumprida. Os cursos de saúde da FCE tem sua formação:

centrada na interdisciplinaridade e na integralidade dos sujeitos e das ações de saúde, levando em conta que a visão integral, subjetiva e singular do modo de viver humano subsidia tanto o processo educativo, quanto as ações profissionais em seus diferentes cenários. (PPP's, 2009, 2010)

\footnotetext{
${ }^{30} \mathrm{http}: / /$ fce.unb.br/sobre-o-curso-fon.

${ }^{31}$ Projeto Político Pedagógico do curso de Farmácia.

${ }^{32}$ Projeto Político Pedagógico de Enfermagem
} 
Quanto às parcerias, o curso de Farmácia, por exemplo, acolheu os alunos de licenciatura em Biologia em seu laboratório multidisciplinar, para aulas práticas, nesta parceria, o Instituto de Biologia (IB).

doou livros, vidrarias, reagentes, bancadas e alguns equipamentos para o laboratório da FCE, melhorando, portanto, a sua capacidade instalada. (PPP, 2010).

Os demais cursos têm parcerias com outras unidades acadêmicas, quer seja com projetos de extensão, projetos de iniciação científica, entre outros.

\title{
4.7. Redução da evasão
}

Por se tratar de uma unidade nova, não é possível fazer um diagnóstico acerca da redução da evasão na FCE. Nisto faremos uma comparação entre os dados apresentados no diagnóstico da UnB inseridos no Plano de Reestruturação de Expansão da Universidade de Brasília com dados indicados por Silva (2016).

O Diagnóstico da Universidade de Brasília, apresentado à Secretaria de Ensino Superior (SeSu) do Ministério da Educação (MEC) informa que:

\begin{abstract}
No período de 2001 a 2005, 26.180 estudantes deixaram a Universidade de Brasília. Destes, 15.195 estudantes (58\%) se formaram e os outros 10.985 estudantes $(42 \%)$ saíram nas seguintes situações: 24\% abandonaram a universidade; $16 \%$ foram desligados por não cumprimento das condições de permanência na universidade, entre eles o baixo desempenho acadêmico; $2 \%$ foram transferidos para outras instituições de ensino superior. (UnB, 2008).
\end{abstract}

Em estudo realizado na Faculdade de Ceilândia, Silva (2016) apresenta dados que indicam que a evasão nos cursos locais é em média de 33\%, ou seja, por este recorte, a evasão na FCE diminui a evasão se comparados ao Diagnóstico apresentado junto ao MEC. 
Gráfico 8 - Taxa de Evasão nos cursos do campi FCE entre 2008/2 e 2014/2

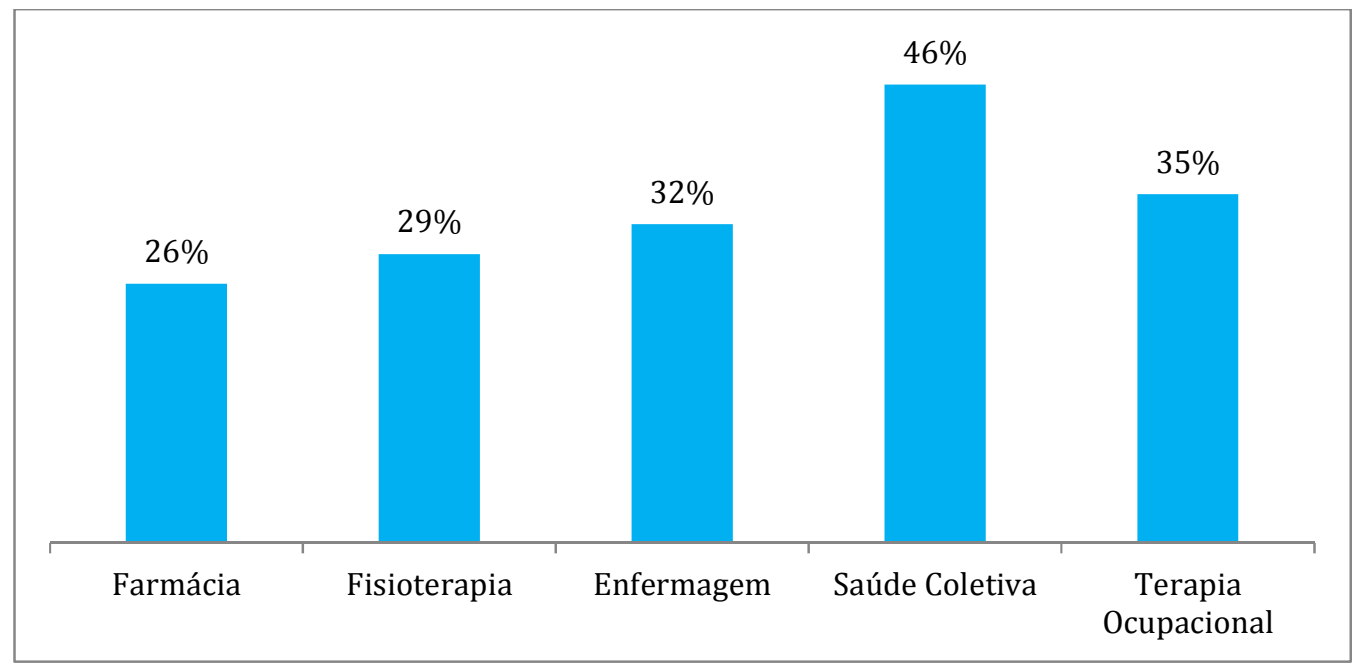

Fonte: Sigra (Silva, 2016).

\subsection{Dados UnB x FCE}

Entre os anos de 2009 e 2015 há uma ampliação considerável no número de novas matrículas, muito em função da adesão da UnB ao Reuni, efetivada em 2008. Com esta adesão novos cursos são criados, como os cursos na área de engenharias, da Faculdade do Gama (FGA) e Ceilândia (FCE), entre outros cursos criados no âmbito da universidade.

Gráfico 9 - Matrículas UnB (2009-2015)

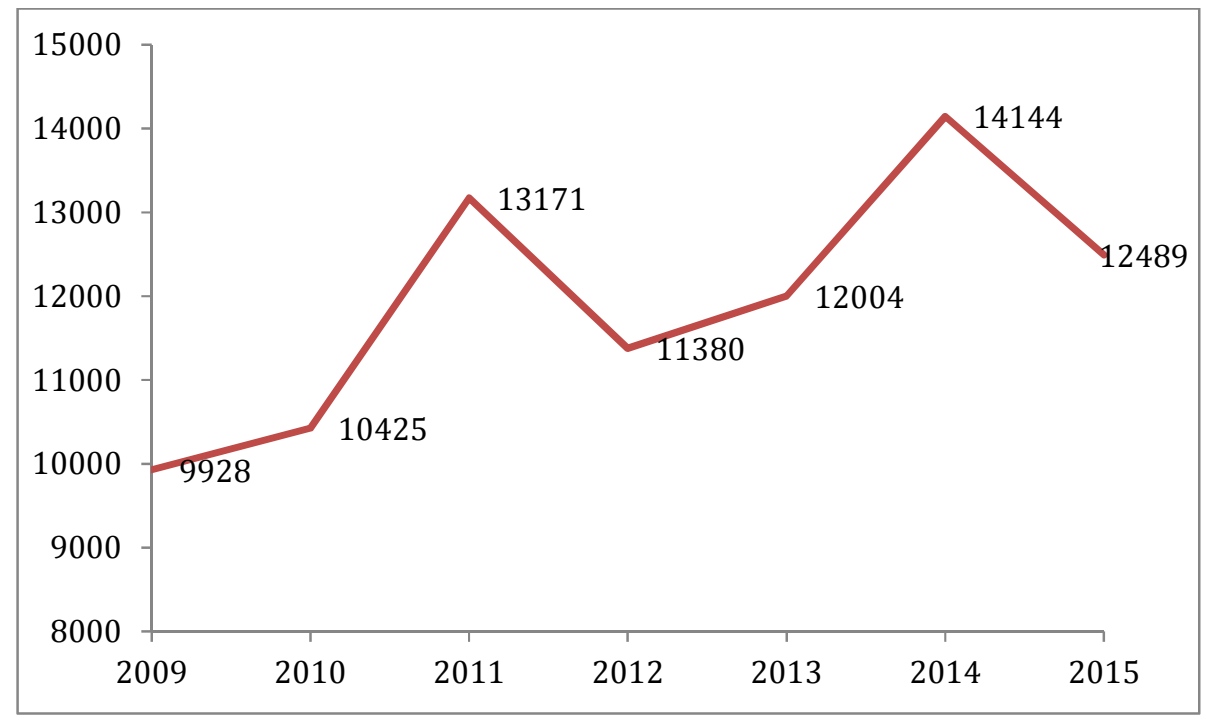

Fonte: Sigra (2016) 
Uma forma de desligamento da Universidade é a evasão. Alguns estudos apontam o fenômeno, que pode se dar por inúmeras variáveis, tais como, ingresso em outros cursos a partir de novos vestibulares, mudança de curso, falecimento, desligamentos, entre outros. Destacamos os trabalhos de Silva (2016) que aborda as mais diferentes variáveis para a evasão nos cursos da área de saúde e Neres (2016), onde compara o perfil e a situação entre alunos egressos e evadidos na Faculdade de Planaltina (FUP).

Gráfico 10 - Evasões UnB (2009-2015)

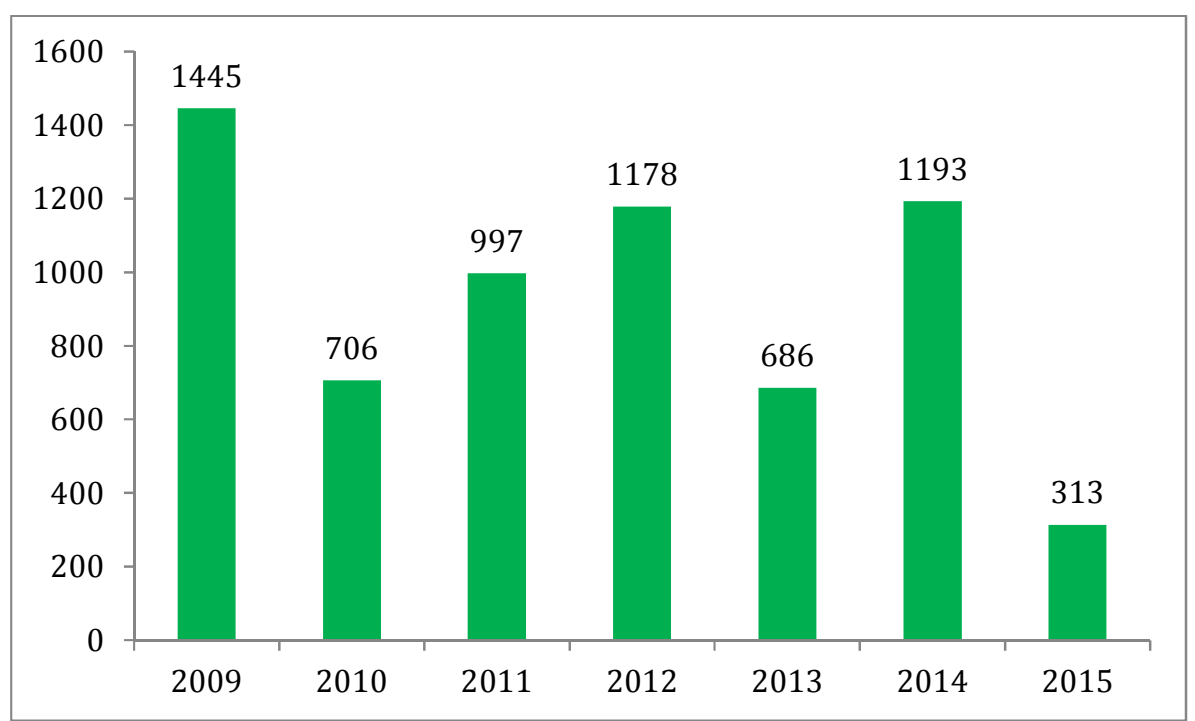

Fonte: Sigra (2016)

Sem adentrar nas variáveis que incidem sobre a evasão, o gráfico 11 apresenta, em termos percentuais, a evasão por ano em relação aos novos discentes matriculados. Nota-se que, com exceção do ano de 2009, a média de evasão nos anos seguintes é de $7 \%$, tendo como $\mathrm{n}^{\mathrm{o}}$ maior de evasões o ano de 2012 e o menor 2015. 
Gráfico 11 - EVASÃO X NÚMERO DE MATRÍCULAS

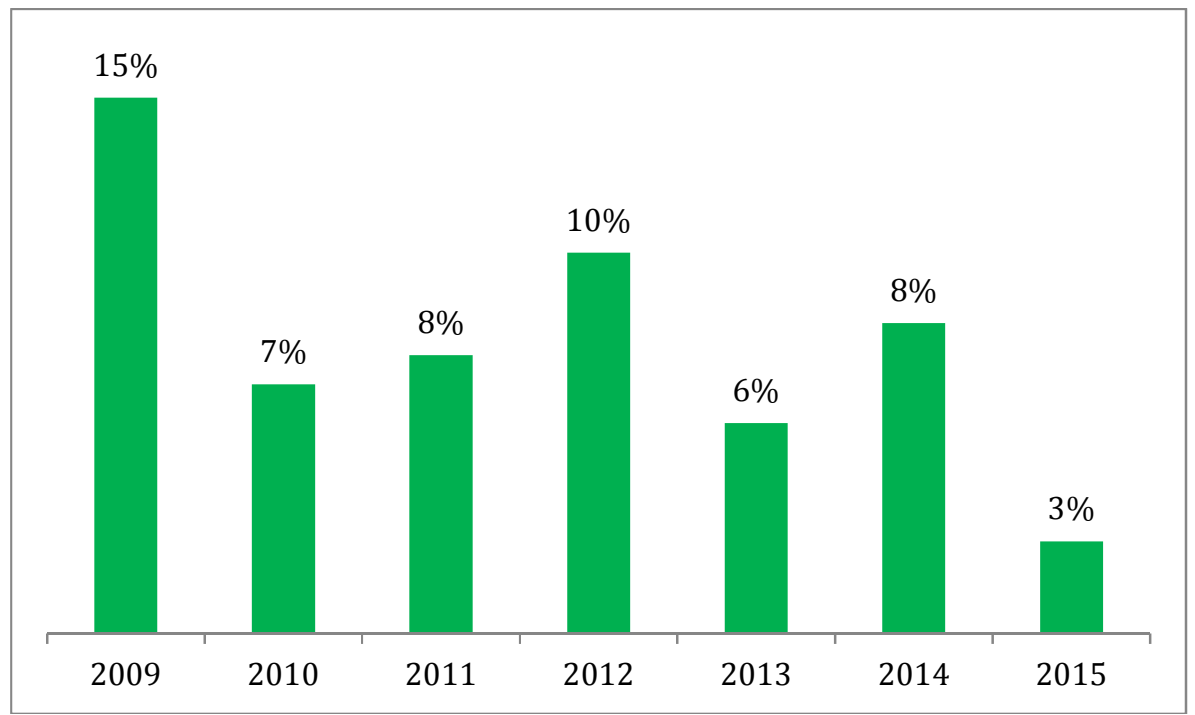

Fonte: Sigra (2016)

Outra forma de saída da universidade é a conclusão do curso. O gráfico 12 apresenta o número de formados entre os anos de 2009 e 2015. Fazendo uma comparação do número de matrículas efetuadas no período frente ao número de formados, nota-se que em média 30\% dos alunos, por ano, se desligam da UnB pela conclusão do curso.

Gráfico 12 - GRÁFICOS FORMADOS, POR ANO (EXLUSIVE FCE)

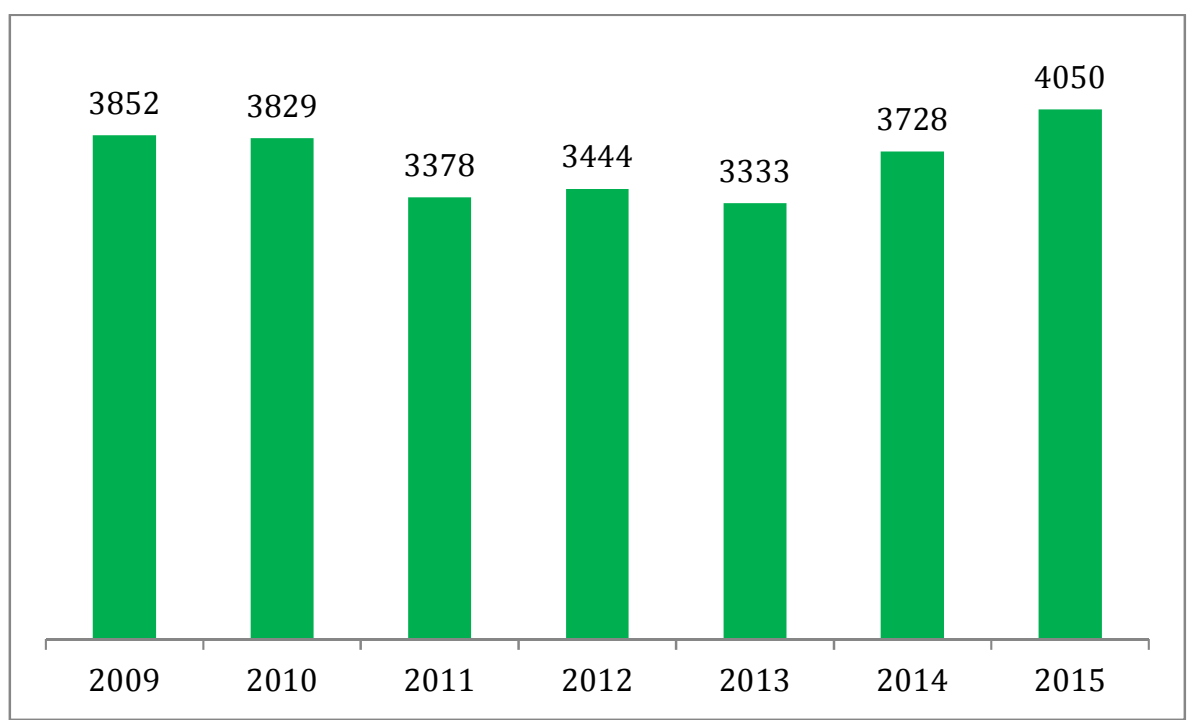

Fonte: Sigra (2016) 
O gráfico 13 apresenta a evolução de matrículas na Faculdade de Ceilândia (FCE) ao longo dos sete anos subsequente são primeiro vestibular, destacando o ingresso de um novo curso no segundo período de 2013, Fonaudiologia.

Gráfico 13 - Matrículas FCE (2009-2015)

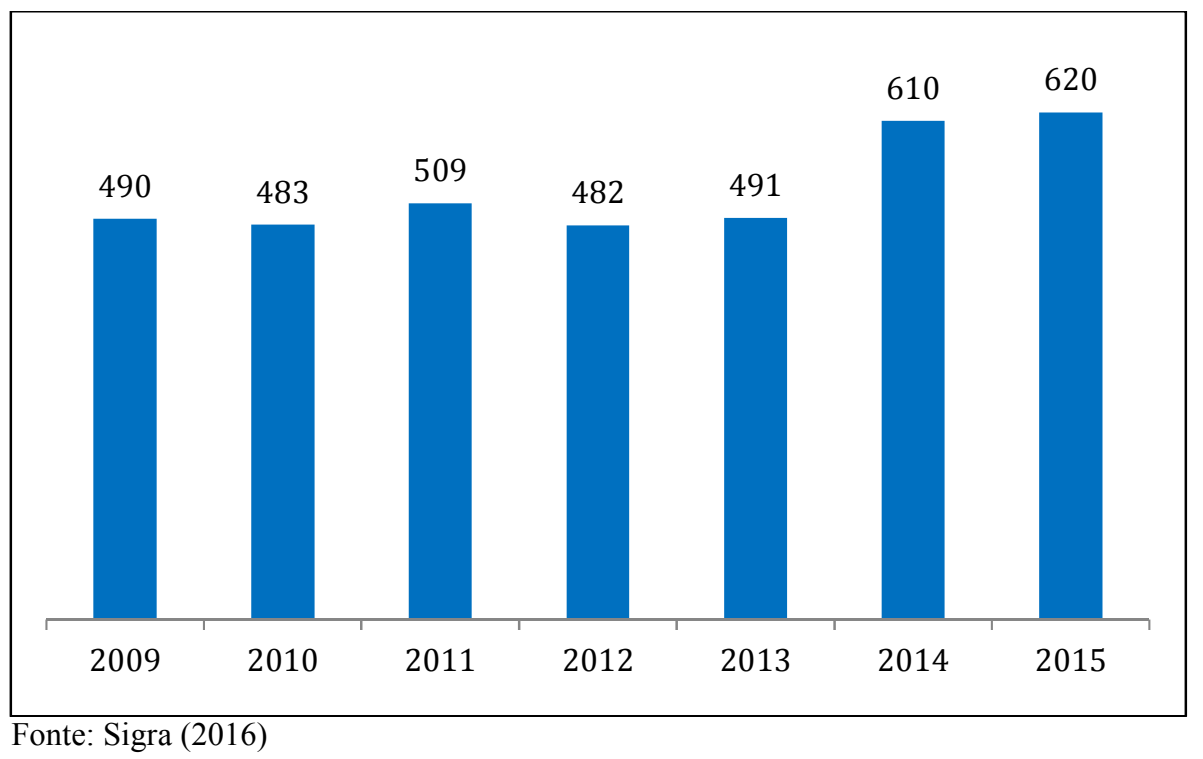

Em 2011 houve um aumento do número de vagas em todos os cursos, no segundo semestre de 2013, se dá o início ao curso fonoaudiologia, mas, não houve preenchimento de todas as vagas. Os anos de 2014 e 2015 houve maior preenchimento das vagas devido ao Sistema de Seleção Unificada (SISU) onde o candidato participante do Exame Nacional do Ensino Médio (ENEM) consegue, a partir de sua nota, verificar as Instituições participantes e os cursos ofertados. Este sistema permite ao candidato optar por um curso já sabendo a provável nota para ingresso. Há também outros tipos de acesso, que, por conta da ociosidade de vagas permitem outras pessoas ingressar como discente da UnB, tais como a seleção de vagas remanescentes, de Portadores de Diploma, e transferência facultativa.

Desde a sua criação em 2008 até o segundo semestre 2015, 732 alunos se formaram na FCE. Os cursos de Saúde Coletiva e Terapia Ocupacional foram os primeiros cursos a terem seus alunos formados, no primeiro semestre de 2012. Os cursos de Enfermagem, Farmácia e Fisioterapia tiveram seus primeiros formandos no primeiro semestre de 2013. 
Gráfico 14 - Distribuição de Formados (por curso)

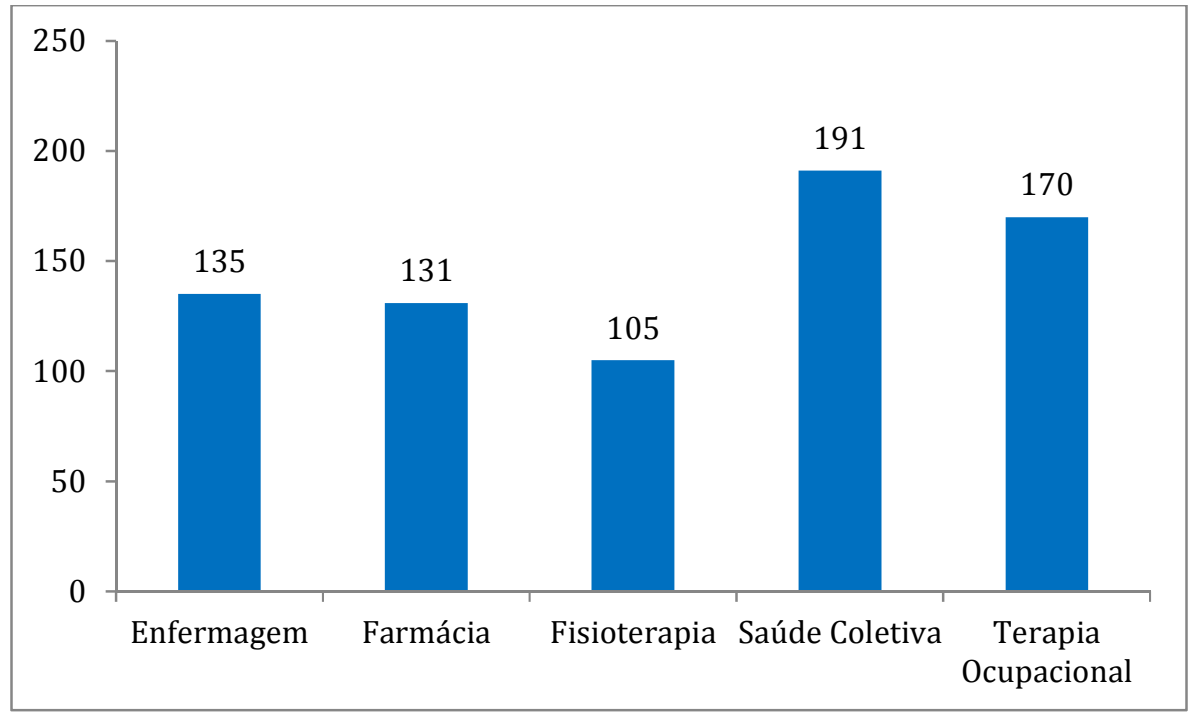

Fonte: Sigra (2016)

O Gráfico 14 apresenta a distribuição dos formandos, por curso, onde o maior número de graduados é o de Saúde Coletiva e o curso com o menor número é o de graduados é o de Fisioterapia. O Curso de Fonoaudiologia ainda não possui graduados devidos ainda não ter completado o ciclo (matrícula, permanência e conclusão).

Comparadas as taxas de concluintes referentes aos ingressos temos em média, na FCE, $47 \%$ de concluintes referentes aos novos matriculados. Destaca-se que a somatória exclui os dados dos alunos matriculados no curso de fonoaudiologia, pois ainda não há formados. Outro detalhe é que, em 2012 só houve formados nos cursos de Saúde Coletiva e Terapia Ocupacional, o que não possibilita a comparação devido aos demais cursos criados em 2008 (Enfermagem, Farmácia e Fisioterapia) não haverem formados no período.

Tabela 3 - Comparação entre o número de novos discentes e formados (2013-2015)

\begin{tabular}{|c|c|c|c|c|c|c|}
\hline \multirow{2}{*}{ Ano } & \multicolumn{3}{|c|}{ UnB (Exclusive FCE) } & \multicolumn{3}{c|}{ FCE } \\
\cline { 2 - 7 } & Matrículas & Formandos & $(\%)$ & Matrículas $(*)$ & Formandos & $(\%)$ \\
\hline 2013 & 12004 & 3333 & $27,77 \%$ & 460 & 184 & $40,00 \%$ \\
\hline 2014 & 14144 & 3278 & $23,18 \%$ & 480 & 248 & $51,67 \%$ \\
\hline 2015 & 12489 & 4050 & $32,43 \%$ & 490 & 251 & $51,22 \%$ \\
\hline
\end{tabular}

Fonte: Sigra (2016)

(*) Não está computado o número de discentes matriculados no curso de fonoaudiologia para fins de comparação, pois somente no Segundo semestre de 2013 teve início o curso de fonoaudiologia. O número de vagas previstas, por semestre é de 35. Portanto, houve uma diminuição no total de matrículas. 
Os cursos da FCE também estão entre os cursos mais bem avaliados. Quatro cursos foram avaliados com conceito 5 da Coordenação de Aperfeiçoamento de Pessoal de Nível Superior (CAPES): Enfermagem, Farmácia, Fisioterapia e Terapia Ocupacional, e o curso de Saúde Coletiva foi avaliado com conceito $4^{33}$.

Outro dado importante é o ingresso de moradores locais. O Relatório do primeiro ano de Gestão do campi FCE aponta que 26\% dos ingressantes de seus cursos são moradores locais, e que somados às Regiões Administrativas de Samambaia e Taguatinga que são próximas e sofrem influência, este número amplia para mais de $50 \%$, ou seja, a expansão da UnB para a Ceilândia facilitou o acesso de moradores das regiões próximas.

\subsection{Projetos de Extensão de Ação Contínua (PEAC) da Faculdade de Ceilândia}

A Universidade de Brasília possui um Decanato específico com vistas a promover as atividades de extensão de todos os setores da universidade (institutos, faculdades, departamentos) tendo por objetivo incentivar a interação entre a UnB e a sociedade, fomentando e pesquisa e ao desenvolvimento social a partir das reflexões e práticas acadêmicas, o Decanato de Extensão (DEX).

Na estrutura do DEX existe a Câmara de Extensão (CEX), cujas atribuições são emitir pareceres, analisar propostas e projetos, regulamentar normas do CEPE e apreciar recursos de decisões dos Conselhos de Institutos e de Faculdades ${ }^{34}$. A CEX é presidida pelo Decano de Extensão e composta por um representante de cada Unidade Acadêmica, um representante dos órgãos complementares e centros afetos a sua esfera de competência e três representantes discentes ${ }^{35}$.

Na Faculdade de Ceilândia existe uma coordenação específica de Extensão, sendo que a coordenadora e a coordenadora-adjunta também são membros do Conselho de Extensão.

Os Projetos de Extensão de Ação Contínua imprimem o caráter de transdisciplinariedade à extensão por sua ação de integração entre a comunidade e a Universidade. São produções vinculadas em sua maioria, de acordo com as

\footnotetext{
${ }^{33}$ Fundação Universidade de Brasília - FUB, Relatório de Avaliação Institucional, 2015.

${ }^{34}$ Art. $3^{\circ}$ da Resolução de Conselho de Ensino, Pesquisa e Extensão no 84 de 1994.

$35 \mathrm{http}$ ://www.unb.br/administracao/camaras/camara_de_extensao, acessado em 5/5/2016.
} 
diretrizes do Fórum Nacional de Pró-Reitores de Extensão das Universidades Públicas Brasileiras - FORPROEXT, às seguintes áreas de conhecimentos ${ }^{36}$.

Gráfico 15 - Quantitativo de Projetos de Extensão de Ação Contínua (PEAC) na Universidade de Brasília (UnB x FCE) - 2013-2015

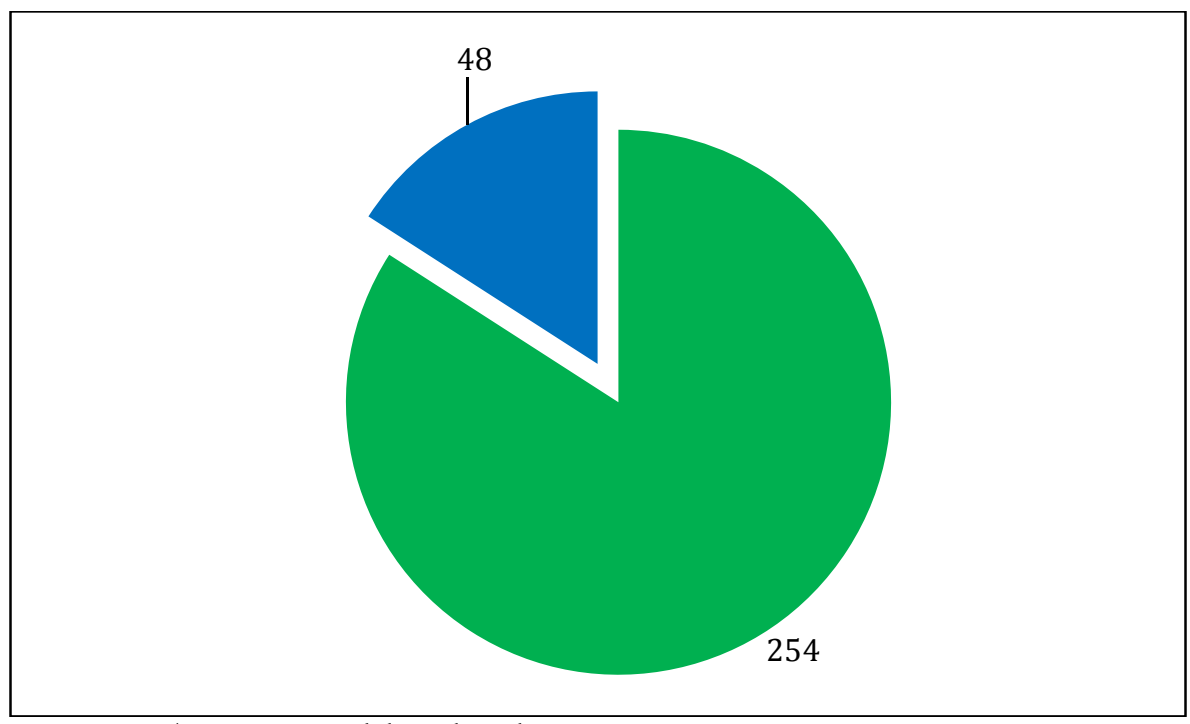

Fonte: DEX/UnB $\quad$ Elaborado pelo autor

Gráfico 16 - Quantitativo de Projetos de Extensão de Ação Contínua (PEAC) na Universidade de Brasília (UnB x FCE) - 2015-2017

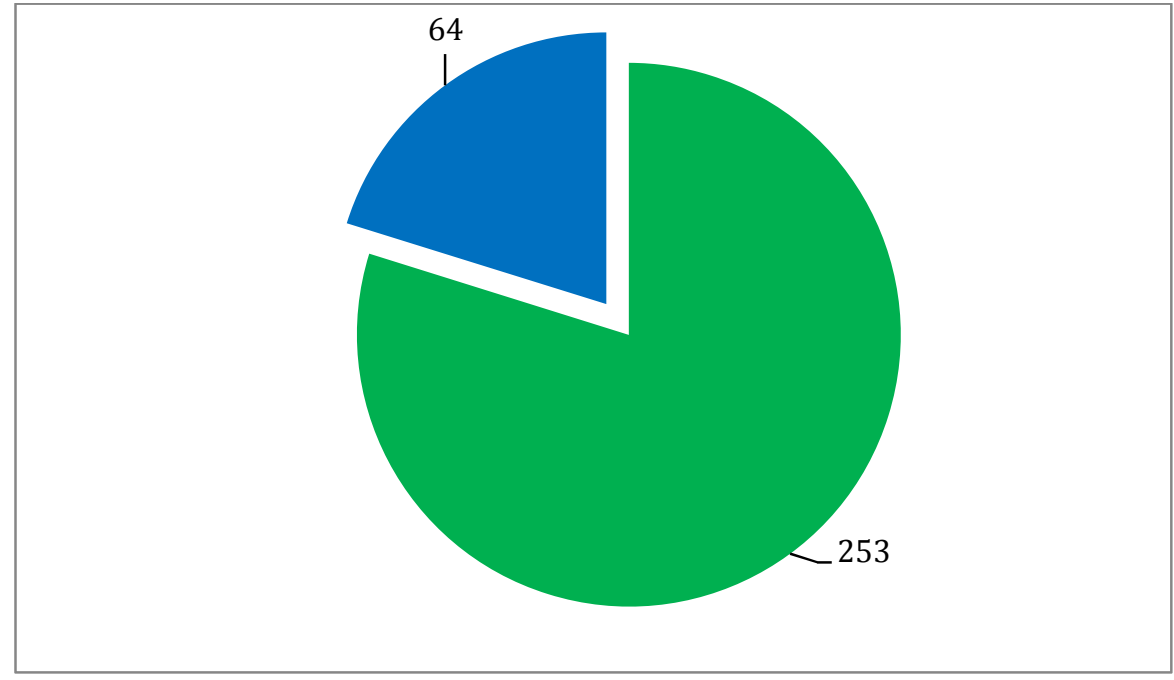

Fonte: DEX/UnB Elaborado pelo autor

\footnotetext{
${ }^{36} \mathrm{http} / /$ unb.br/administracao/diretorias/dte/r_peacs.html, acessado em 5/5/2016.
} 
Os gráficos 15 e 162 apresentam dados referente ao quantitativo de Projetos de Extensão de Ação Contínua (PEAC) entre os anos de 2013 e 2015 (Executados ou em fase final de execução) e entre os anos de 2015 e 2017 (em execução).

Entre os anos de 2013 e 2015 o Decanato de Extensão aprovou 302 projetos, destes, 48 referem-se à Faculdade de Ceilândia, representado $16 \%$ do total de projetos da Universidade de Brasília.

Segundo o Relatório dos Projetos de Extensão de Ação Contínua (PEAC) do Decanato de Extensão para os anos de 2015 a 2017, foram aprovados 317, e destes, 64 estão sendo executado pela Faculdade de Ceilândia, um acréscimo de 16 novos projetos, o que representa $20,2 \%$ do total de projetos.

\section{Gráfico 17 - Comparativo de Projetos de Extensão de Ação Contínua (PEAC) entre os três campi (FCE, FGA e FUP) - 2013-2015}

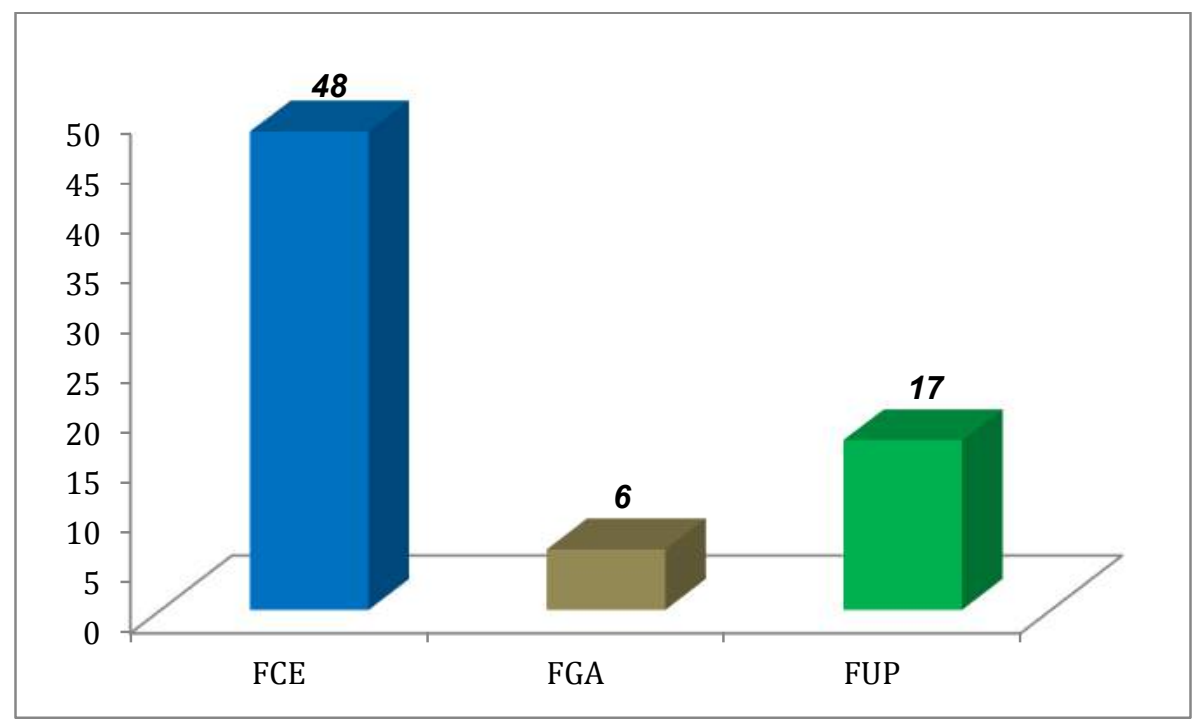

Fonte: DEX/UnB

Quando comparado os três novos campi: Faculdade de Ceilândia (FCE), Faculdade do Gama (FGA) e Faculdade de Planaltina (FUP), percebe-se que a Faculdade de Ceilândia tem a maior parcela de projetos do total. Conforme dito anteriormente, a FCE é responsável, ente os anos de 2013 e 2015 , por $16 \%$ do total de projetos da UnB, por outro lado, os projetos desenvolvidos pela FGA representam $2 \%$ e pela FUP 5,5\%.

Segundo opinião de uma ex-coordenadora de extensão: 
Nos últimos dois anos, a área da extensão da FCE atingiu cerca de uma centena de atividades de extensão seja em Programas e Projetos de Ação Continua ou cursos e minicursos. A explicação para essa "corrida para a extensão", se deu, principalmente, devido a área da saúde na qual os seis cursos de graduação e os dois cursos de pós graduação estão inseridos. Por outro lado, não basta realizar as ações de extensão, é necessário oficializá-las de acordo com as normas do Decanato de Extensão. Essas normas estão muito bem claras nas Resoluções 60/2015 do CEPE e 01/2015 da CEX. A Resolução 60/2015 do CEPE, no seu art $1^{\circ}$ descreve os conceitos de extensão e exemplifica os tipos de atividades de extensão. Por esse motivo, os docentes e os técnicos administrativos procuraram inserir no Sistema de Extensão, SIEX, as suas propostas de atividades, permitindo a realização de ações extensionistas em diversos setores como, centros de saúde, escolas, hospitais e outros.

\section{Gráfico 18 - Comparativo de Projetos de Extensão de Ação Contínua (PEAC) entre os 3 campi (FCE,} FGA e FUP) - 2015-2017

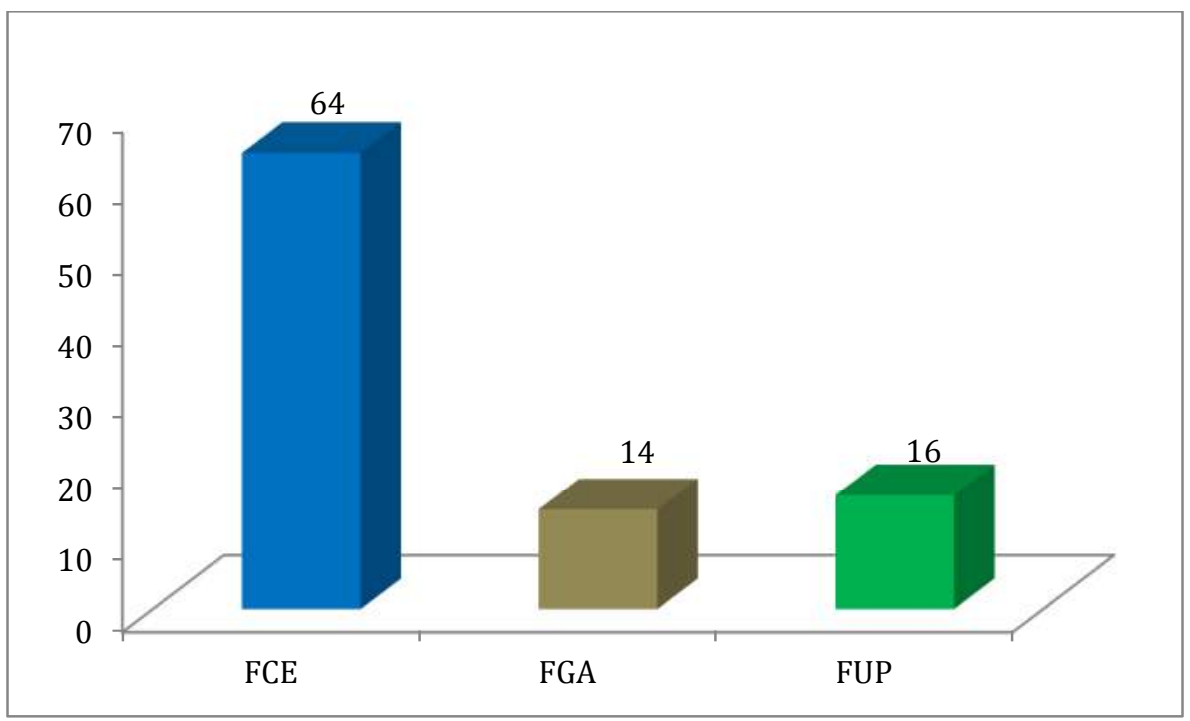

Fonte: DEX/UnB

Há um acréscimo significativo de projetos aprovados pelo DEX para a Faculdade de Ceilândia, ampliando em 16 projetos, ou 1/5 do total de projetos da UnB. A FGA, apesar de dobrar em termos percentuais $(4,4 \%)$, continua com uma parcela pequena de projetos, e a FUP permanece quase estagnada, e diminuindo em relação ao total de projetos (5\%). 
Gráfico 19 - Localidade de realização dos Projetos de Extensão de Ação Contínua (PEAC) da FCE

(2013-2015)

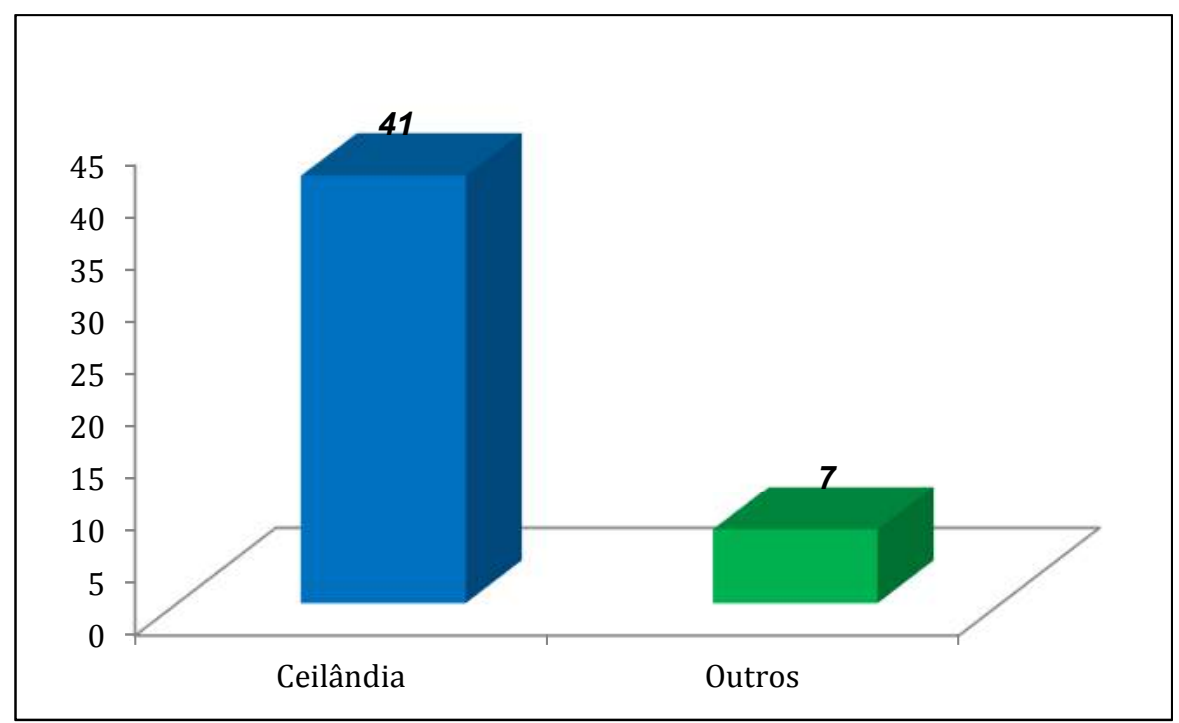

Fonte: DEX/UnB

Os projetos aprovados pelo Decanato de Extensão de 2013 a 2015 apontam uma parte considerável de Projetos de Extensão de Ação Contínua (PEAC) da Faculdade de Ceilândia com atuação direta na comunidade de Ceilândia, mudando o quadro de influência. Do total de 48 projetos, 41 atuam diretamente na comunidade de Ceilândia, justificando a expansão proposta e atendida da universidade, em termos percentuais, de $85 \%$ dos projetos tem atuação direta ou indireta, e somente $15 \%$ tem relação com outras cidades como Brazlândia, Taguatinga, Brasília, Núcleo Bandeirante, que são áreas de influência da Ceilândia. (FCE, 2008). 
Gráfico 20 - Localidade de realização dos Projetos de Extensão de Ação Contínua (PEAC) da FCE

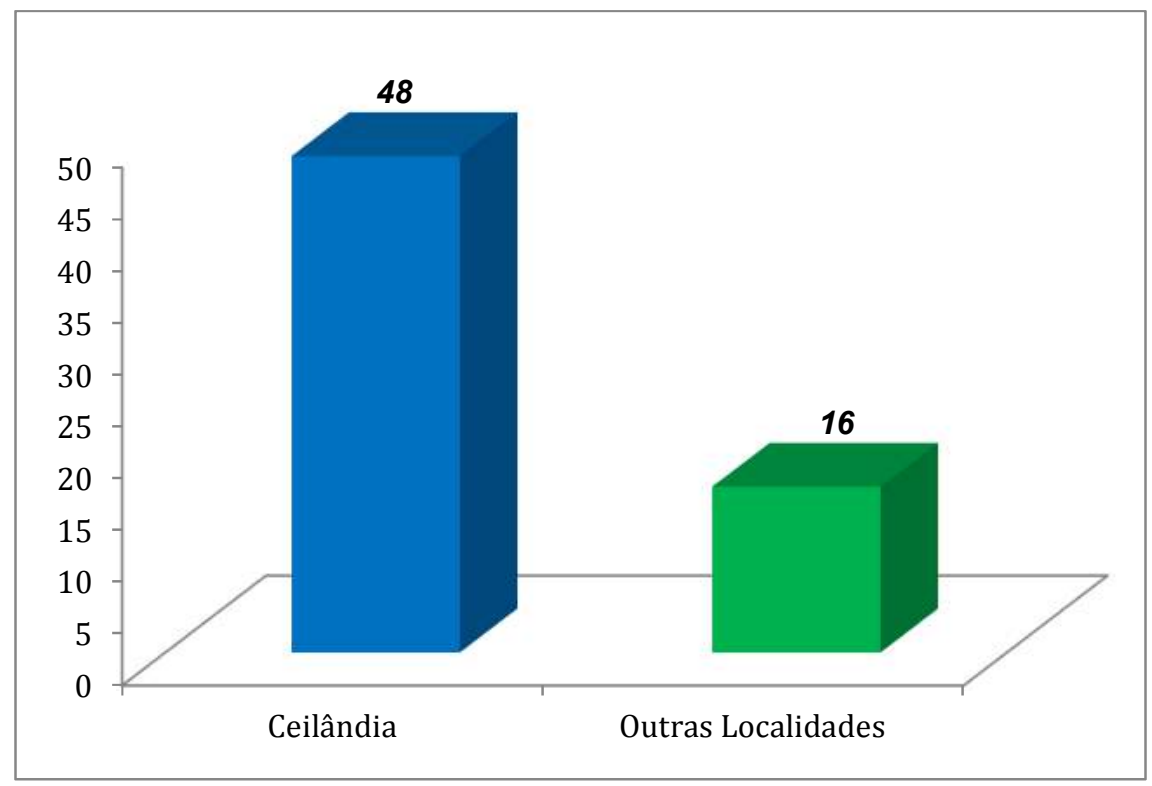

Fonte: DEX/UnB

Dos projetos aprovados para os anos de 2015 a 2017, houve um maior número de projetos aplicados na cidade de Ceilândia, saltando de 41 para 48, porém, um decréscimo de atuação na cidade, se comparado com os demais projetos. Cabe ressaltar que dos 16 projetos computados em outras localidades, 5 são no Hospital Universitário (HUB), 6 são em Regiões circunvizinhas de Ceilândia (Recanto das Emas, Taguatinga e Brazlândia) e 1 é um blog.

\subsection{Programas de Extensão e outras atividades de Extensão da Faculdade de Ceilândia}

A Faculdade de Ceilândia (FCE) também tem desenvolvido outras atividades de Extensão, tais como cursos, minicursos, Programas, Semanas Universitárias e outros eventos. Os Eventos abaixo relacionados são de curta duração, o que envolve praticamente a comunidade universitária.

Tabela 4 - Atividades de Extensão (*)

\begin{tabular}{|l|c|}
\hline \multicolumn{1}{|c|}{ Atividades } & Quantidade \\
\hline Semana Universitária & 80 \\
\hline Mini cursos & 6 \\
\hline Eventos & 14 \\
\hline
\end{tabular}




\begin{tabular}{|l|c|}
\hline Cursos & 15 \\
\hline Fonte: DEX/CEX
\end{tabular}

(*) Não foram computados os Programas de Extensão.

As atividades voltadas à Semana Universitária são momentos voltados à divulgação da produção acadêmica. Além disso, promove o diálogo e troca de conhecimento com a sociedade, tendo por tradição "fortalecer a sinergia entre extensão, pesquisa e ensino"37 e acontece geralmente na última semana do mês de outubro ou na primeira semana do mês de novembro, onde em 2016 acontecerá a $15^{\text {a }}$ Edição.

Outras modalidades de Extensão são classificadas, segundo portal da UnB como:

\begin{abstract}
Cursos de Extensão: são aqueles ministrados na Universidade de Brasília (UnB) que respondem a demandas não atendidas pela atividade regular do ensino formal de graduação ou de pós-graduação. Esses cursos podem ser predominantemente presenciais, a distância ou via rede. Eles podem, ainda, utilizar uma combinação de todas essas metodologias. Os cursos com carga horária entre 10 e 29 horas são chamados Minicursos.

Eventos: são atividades de curta duração como palestras, seminários, exposições, congressos, entre outras, que contribuem para a disseminação do conhecimento. Destacam-se os Eventos Regulares, cuja recorrência permite que esses sejam programados a cada ano.

Programas Especiais: compreendem atividades de duração determinada que inicialmente não se enquadram na estrutura básica do Decanato de Extensão (DEX). São criados mediante proposta do DEX aprovada pela CEX.

Programas Permanentes: são empreendimentos que se caracterizam por uma organização estável e por disponibilizar a divulgação científica, artística e cultural.
\end{abstract}

Sete Programas de Extensão estão em execução, dos quais houve o acompanhamento, em três oportunidades junto ao Programa de Extensão "Prevenção e reabilitação em idosos e adultos jovens cardiopatas ou não e sua inserção no esporte" onde foi aplicado o mesmo questionário utilizado no Projeto de Extensão de Ação Contínua (PEAC).

\title{
5. RESULTADOS
}

O presente capítulo trata da apresentação e análise de dados do referente ao questionário aplicado junto aos beneficiários do Programa de Extensão: "Prevenção e reabilitação em idosos e adultos jovens cardiopatas ou não e sua inserção no esporte" e do Programa de Extensão e Ação Contínua "Saúde Integral em Famílias Carentes do Distrito Federal”.

\footnotetext{
${ }^{37}$ www.semanauniversitaria.unb.br, acessado em 05/08/2016.
} 


\subsection{Programa de Extensão: "Prevenção e reabilitação em idosos e adultos jovens cardiopatas ou não e sua inserção no esporte".}

O Programa é desenvolvido no Laboratório Ginásio Terapêutico onde, a partir de atividades físicas esportivas promove a melhoria na capacidade cardiorrespiratória em busca de uma maior qualidade de vida limitada provocada pela idade e/ou doença cardiovascular. ${ }^{38}$.

\section{Público e Local da Pesquisa:}

O Programa é destinado a jovens, adultos e idosos portadores de cardiopatia ou não. As atividades acontecem no Laboratório de Fisiologia do Exercício e Biofísica da FCE. As atividades são supervisionadas e coordenadas sempre por um professor e o acompanhamento clínico feito por um aluno de estágio. Cinco professores acompanham o programa, 35 estudantes e 16 beneficiários.

Ao analisar os dados do questionário constatamos que no primeiro bloco de perguntas $^{39}$ constatamos o público quanto ao perfil socioeconômico dos participantes, onde:

Gráfico 21 - Sexo

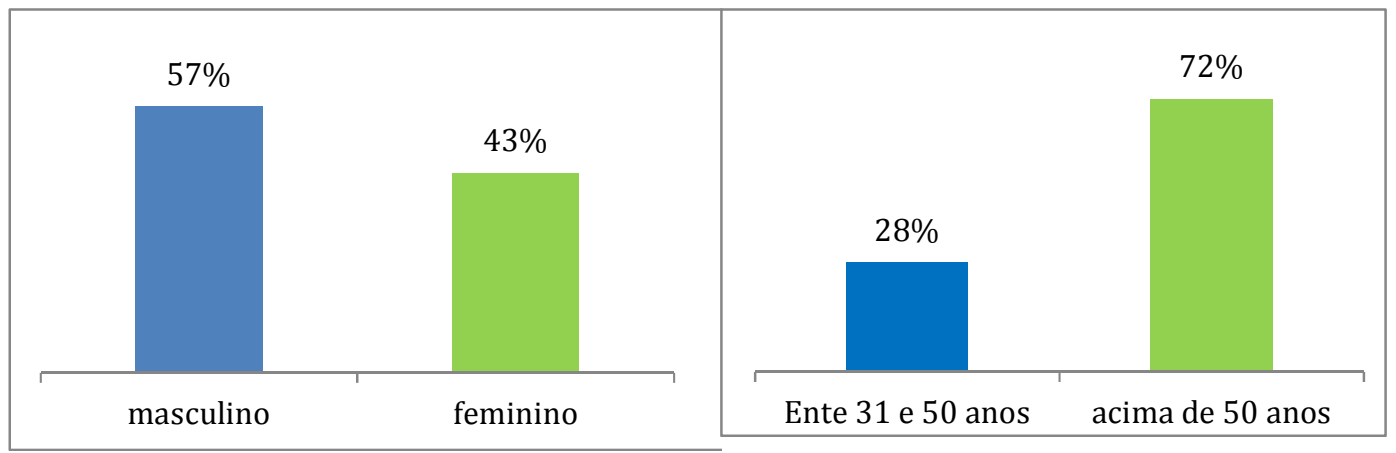

O Gráfico 21 apresenta um equilíbrio entre os participantes, com ligeira maioria para o sexo masculino. Destes, a maioria (72\%) tem idade superior a 50 anos de idade, conforme gráfico 22. O gráfico 22 ratifica a proposta inicial do projeto no atendimento, porém, nota-se que 3/4 dos participantes tem idade superior aos 50 anos.

\footnotetext{
${ }^{38}$ Proposta de Ação de Extensão n ${ }^{\circ} 54757$.

${ }^{39}$ Foi aplicado um Questionário semiestruturado.
} 
A pesquisa aponta também que a maioria $(85 \%)$ dos beneficiários pesquisados tem renda inferior a 2 salários. Quanto à localidade, 2/3 dos entrevistados são moradores da Região Administrativa de Ceilândia, apontando, ainda, que há beneficiários de outras localidades.

Quanto ao nível de satisfação, a comunidade beneficiária foi unânime em apontar a satisfação com o projeto, onde os comentários (proposto em uma questão aberta) foram a de excelência das atividades, a proximidade dos moradores para participarem do programa, o excelente nível no atendimento, por parte dos colaboradores (alunos e professores), consideram, por suas condições econômicas, como uma oportunidade única em participar, uma vez que provavelmente não teriam a mesma atenção e oportunidade em outras instituições. Ressaltam ainda que os resultados são animadores, pois, para a ampla maioria ( $85 \%)$ os níveis de saúde melhoraram.

\subsection{Projeto de Extensão: "Saúde Integral em Famílias Carentes no Distrito Federal"}

O projeto é uma extensão universitária pioneira na Universidade de Brasília, onde já atua há 17 anos em comunidades carentes do Distrito Federal, tias como Paranoá, Estrutural e Santa Maria. A atuação do projeto na comunidade de Ceilândia se deu a partir da professora Engracia dos Santos (Terapia ocupacional), que ficou responsável pelo setor e atua, no bairro Sol Nascente desenvolvendo projetos e ações específicas integradas.

\section{Público e Local da Pesquisa:}

O campo de atuação do projeto saúde integral é o bairro do Sol Nascente, na Região Administrativa de Ceilândia e é composta por pessoas de baixa renda, com diferentes inserções no mundo do trabalho, existindo também um grande número de desempregados, contando com cerca de 100 beneficiários participantes. As atividades desenvolvidas na comunidade visam:

Vivências junto às Famílias onde as sextas a tarde, pela manhã, as duplas de estudantes de diferentes cursos visitam famílias previamente identificadas pela Equipe de Saúde da Família (ESF) ou por lideranças da comunidade na qual o 
diálogo se faz determinante na ampliação dos vínculos afetivos, buscando-se, em conjunto, as soluções para os problemas cotidianos frente às adversidades ditadas pela supremacia da subordinação e opressão das classes sociais; Atuação junto aos Grupos de Cuidados existentes na Unidade de Saúde da Família local, para a discussão e desenvolvimento de ações específicas, demandadas pelas próprias visitas realizadas às famílias, ou se integrando a um dos Grupos de Cuidados existentes na Unidade de Saúde (Adolescente, Crianças, Gestantes, Mulheres e Idosos)

Os alunos também atuam diretamente na comunidade sob a supervisão de um professor, responsável pela coordenação e supervisão do projeto.

\section{$\underline{\text { Análise de Dados }}$}

Foram aplicados os questionários, conforme anexo, para 21 beneficiários do Projeto. A participação feminina é significativa, do total de entrevistados somente três homens responderam o questionário. Do total de mulheres entrevistadas apenas uma tem emprego formal e as demais não possuem emprego fixo, o que reflete na renda per capita das famílias não superando 2 salários mínimos. A totalidade dos beneficiários moram na localidade do Sol Nascente.

Quanto ao nível de satisfação, a comunidade beneficiária foi unânime em apontar a satisfação com o projeto, onde os comentários (proposto em uma questão aberta) foram a de que o projeto tem que continuar, informa a importância do projeto na mudança de suas vidas, pois a vida na localidade é muito difícil, a interação dos alunos também é informada, onde os alunos colocam em prática sua experiência . Consideram, ainda, que por suas condições econômicas e pela vulnerabilidade social a qual estão expostas, o Projeto "mudou" a vida das pessoas locais, inclusive na questão de saúde, onde todas as pessoas entrevistadas nunca tiveram este tipo de acompanhamento e que melhoraram significativamente seu estado de saúde.

A metodologia do projeto saúde integral baseia-se em visitas semanais às famílias da Comunidade do sol nascente realizadas por estudantes de cursos distintos. A escolha das famílias é realizada de acordo com a necessidade da própria comunidade, o que corresponde a uma indicação de algum morador, líder comunitário, ACS e demais membros da equipe do Programa Saúde da Família. Os estudantes chegam às casas em duplas, sendo cada uma formada por graduandos de cursos diferentes. As visitas são orientadas numa perspectiva dialógica, pautada na troca de saberes e compartilhamento de opiniões.

Foi feita uma pergunta à coordenadora do Projeto de Extensão acerca dos encontros e sua relação com a comunidade local, bem como suas impressões: 
Esse encontro semanal com a família cria e fortalece um vínculo do extensionista com os moradores, desestruturando ideias de superioridade/inferioridade, distanciamento e incapacidade, mecanismos de autoproteção de ambos os lados, dando lugar à igualdade, aproximação e superação de obstáculos. As visitas são espaços para as famílias falarem e serem ouvidas, uma ação que parece simples, mas absurdamente em falta na sociedade individualista vigente.

No ambiente acadêmico são realizadas reuniões semanais, cujo conteúdo varia de questões de organização e aprofundamento teórico à discussão da situação das famílias e relações interpessoais entre os próprios participantes do projeto.

As duas atividades de extensão em pauta, sugerem a importância da expansão da Universidade de Brasília e que, exclusivamente, em função de estar na comunidade de Ceilândia, contribuiu com suas ações nas comunidades pesquisadas e cumpre a diretriz $\mathrm{E}$ do Reuni, que ponta o compromisso social da UnB onde estes novos atores são beneficiários, a partir destas atividades.

O questionário aplicado aos beneficiários das duas atividades de extensão estudadas permite, ainda, perceber o quão importante tem sido a atuação da Universidade de Brasília na comunidade local. Um dos entrevistados, ao responder a questão sobre esta importância, indica que a atuação da UnB é:

"Muito Importante, é uma conquista para nós morador de Ceilândia, e o projeto também um passo a frente é de grande ajuda."

Outro beneficiário aponta que:

"Só tenho falar coisas boas, nos ajuda bastante trazendo pessoas com ideias. Gosto muito é satisfatório."

No que diz respeito aos efeitos das atividades de extensão, destaca-se que, segundo outro entrevistado:

"Tudo de bom para nós, aqui é tudo difícil, o projeto tem melhorado a vida da comunidade". 
Houve, ainda, consulta aos alunos, onde, as atividades extensionistas permitem aos discentes através da participação na comunidade verificar a realidade que incidirá em sua profissão, no futuro:

"Gosto da possibilidade de vivenciar uma realidade que estigmatizada e conhecer um pouco do que é real, que muitas vezes vai de contrário as ideias pré-concebidas em relação ao território. Todo território tem as suas particularidades e o contato com a comunidade permite romper a barreira do estereótipo construído sobre o sol nascente."

Houve uma significativa contribuição, tanto do ponto de vista acadêmico, como o ingresso de moradores locais de regiões circunvizinhas e baixa renda, quanto para a comunidade que tem nas atividades de extensão desenvolvidas na comunidade local, e que sequer sabia da existência deste tipo de ação. A Adesão da UnB ao Reuni está diretamente ligada na expansão da universidade à comunidade de Ceilândia. 


\section{CONSIDERAÇÕES FINAIS}

Ao findar este trabalho, resgatamos a questão inicial proposta que foi a reflexão acerca da contribuição da Faculdade de Ceilândia, unidade da Universidade de Brasília, para a comunidade local.

Buscou-se apresentar os dados acerca da expansão do ensino superior público e privado, desde a década de 1960 até o início dos anos 2000, na tentativa de refletir sobre a democratização no acesso ao ensino superior no Brasil, a partir de alguns teóricos.

Para que efetivamente a UnB expandisse sua atuação, já prevista no início do século XXI, foi importante a sua adesão ao Programa de Apoio a Planos de Reestruturação e Expansão das Universidades Federais (Reuni).

Foi explicitado que o processo de adesão da UnB ao Reuni tencionou a comunidade acadêmica o que adiou este acordo de 2007 para 2008 quando, enfim, pode ser discutida com o conjunto de atores da universidade.

Com esta adesão a UnB garantiu recursos que possibilitaram executar o planejamento da expansão física, onde o governo do Distrito Federal (GDF) cedeu espaço para a construção do novo campi.

Com os recursos do Reuni, foi possível também, a contratação dos mais variados equipamentos para a área administrativa, laboratórios, salas de aula, entre outros e a contratação de profissionais técnicos administrativos e docentes, chegando assim, ao pleno funcionamento da FCE.

Ao discorrer sobre o processo de implantação da UnB na Ceilândia, buscou-se apresentar a Região Administrativa de Ceilândia, a fim de situar a comunidade local, intentando os problemas de exclusão, de dificuldades que circundam a localidade.

A instalação provisória da FCE no Centro de Ensino Médio demorou cerca de 3 meses após a estadia no Núcleo de Práticas Jurídicas da Faculdade de Direito, em Ceilândia, 
possibilitando assim o início das aulas no segundo semestre de 2008. No Início de novembro do mesmo ano, as aulas foram transferidas para o campi provisório.

A longa espera, entre 2008 e 2013, fez com que as obras demoraram em ser entregue, devido a sucessivos problemas quer seja de ordem institucional (troca de governadores), quer seja e inexecução ou execução incompleta do contrato com a empreiteira, tendo por desfecho o cancelamento do contrato e a retomada, por parte da Universidade, para completar a obra.

A expansão da UnB para a Região Administrativa de Ceilândia permite concluir que, a partir da compreensão da educação como um bem público, houve um aumento no ingresso de novos discentes moradores da Ceilândia e regiões circunvizinhas, como Taguatinga, Samambaia entre outras, que ingressaram na educação superior pública cumprindo a principal meta do Reuni, a partir da adesão pela UnB.

Ao iniciar suas atividades na Ceilândia, a FCE, a partir das atividades de extensão apontam a necessidade de se colocar em prática a integração entre ensino, serviço e comunidade.

Isso torna-se necessário uma vez que ao desenvolver nos estudantes a responsabilidade social e humanização no atendimento, estes têm oportunidade de vivenciarem na prática a realidade das populações e os determinantes sociais que as cercam.

As atividades de extensão pesquisadas e tanto na comunidade do Sol Nascente quanto no Laboratório Ginásio Terapêutico, apresenta uma interação entre a universidade e a sociedade permitindo ao aluno dos cursos da FCE, aos professores, esta interação com a comunidade pondo em prática os eixos integradores da extensão universitária.

A prática da extensão destaca a experiência que os alunos adquirem no contato com a comunidade beneficiária que incidirá de forma positiva na prática profissional destes futuros profissionais.

Para que efetivamente a UnB expandisse sua atuação, já prevista no início do século XXI, foi importante a sua adesão ao Programa de Apoio a Planos de Reestruturação e Expansão das Universidades Federais (Reuni). 
Com esta adesão a UnB garantiu recursos que possibilitaram executar o planejamento da expansão física para a Ceilândia, o aumento do número de matrículas de novos discentes moradores da região e a efetiva participação da comunidade universitária, por meio das atividades de extensão.

A expansão da Universidade de Brasília para a Ceilândia cumpre sua missão institucional, principalmente no que tange ao seu papel transformador na sociedade, contribuindo para a inserção da população, em um primeiro momento, com a maior possibilidade de inserção como discente em uma universidade pública (1.200\%) e, num segundo momento, como explicitado nesta dissertação, a contribuição direta para a comunidade, as atividades de extensão, que incidem diretamente na vida das pessoas, principalmente do ponto de vista da melhoria na saúde. 


\section{REFERÊNCIAS BIBLIOGRÁFICAS}

ARAÚJO, Maria Arlete Duarte; PINHEIRO, Helano Diógenes. Reforma gerencial do Estado e rebatimento no sistema educacional: um exame do REUNI. Ensaio: aval. pol. públ. Educ., v. 18, n. 69, p. 647-668, dez. 2010.

BRASIL. FUB. Plano de reestruturação da universidade de Brasília.

BRASIL. Planalto. Lei 9.394, de 20 de Dezembro de 1996. Estabelece as diretrizes e bases da educação nacional. Disponível em: http://www2.senado.leg.br/. Acesso em: 5. mar. 2016.

BRASIL. Planalto. Lei 9.394, de 20 de Dezembro de 1996. Estabelece as diretrizes e bases da educação nacional. Disponível em: http://www.planalto.gov.br/ccivil_03/leis/19394.htm. Acesso em: 8. julho. 2016.

BRASIL. Plano de reestruturação e expansão da Universidade de Brasília. Brasília: FUB, 2008.

BRITO, Maria Ivoneide de Lima. Implementação do REUNI na UnB (2008-2011): limites na ampliação de vagas e redução da evasão. 2014.

DENZIN, Norman K.; LINCOLN, Yvonna S. O planejamento da pesquisa qualitativa: teorias e abordagens. In: O planejamento da pesquisa qualitativa: teorias e abordagens. Artmed, 2006.

DOURADO, Luiz Fernandes. Políticas e gestão da educação superior no Brasil: múltiplas regulações e controle. Revista Brasileira de Política e Administração da Educação-Periódico científico editado pela ANPAE, v. 27, n. 1, 2011.

FÁVERO, Maria de Lourdes de Albuquerque. A Universidade no Brasil: das origens à Reforma Universitária de 1968 University in Brazil: from its origins to university reform1968. 2006.

FUNDAÇÃO UNIVERSIDADE DE BRASÍLIA (FUB). Plano orientador da Universidade de Brasília. Brasília: Editora UnB, 1962.

GIL, A. C. Como elaborar projetos de pesquisa. 4. ed. São Paulo: Atlas, 2007.

MAIO, Marcos Chor; SANTOS, Ricardo Ventura. Política de cotas raciais, os "olhos da sociedade" e os usos da antropologia: o caso do vestibular da Universidade de Brasília (UnB). Horizontes antropológicos, v. 11, n. 23, p. 181-214, 2005.

MANCEBO, Deise. Reforma universitária: reflexões sobre a privatização e a mercantilização do conhecimento. Educação e Sociedade, v. 88, p. 13-20, 2004. 
MARTINS, Carlos Benedito. A reforma universitária de 1968 e a abertura para o ensino superior privado no Brasil. Educação e Sociedade, v. 30, n. 106, p. 15-35, 2009.

MELO, Lívia Veleda de Sousa. A concepção e a implantação de novos campi da UnB no DF e seus efeitos sobre a democratização do acesso. 2014.

MOTA SOBRINHO, Alexsandro. Os limites e as possibilidades do Programa Reuni: um estudo de caso da experiência da UFT. 2016.

NOGUEIRA, Jaana Flávia Fernandes. Reforma da educação superior no governo Lula: debate sobre ampliação e democratização do acesso. 2008.

RISTOFF, Dilvo I. Políticas para a educação superior no Brasil: deselitização e desprivatização. Políticas e gestão da educação superior. Curitiba: Champagnat, 2003.

SAVIANI, Dermerval. A questão da reforma universitária. Educação \& Linguagem/Ano, v. 7, 2004.

SGUISSARDI, Valdemar. Modelo de expansão da educação superior no Brasil: predomínio privado/mercantil e desafios para a regulação e a formação universitária. Educação \& Sociedade, v. 29, n. 105, p. 991-1022, 2008.

SILVA, Fernanda Cardoso da. O desempenho acadêmico e o fenômeno da evasão em cursos de saúde. 2016

SILVEIRA, Ana Paula. Reuni: Senta que lá vem história.... 2015.

TEIXEIRA, Marta Emília. O impacto do REUNI sobre a gestão administrativa e financeira da Universidade de Brasília. 2013. 
8. ANEXOS 
ANEXO A - Imagens FCE

Figura 1 - CEM 4 - Antes da Reforma

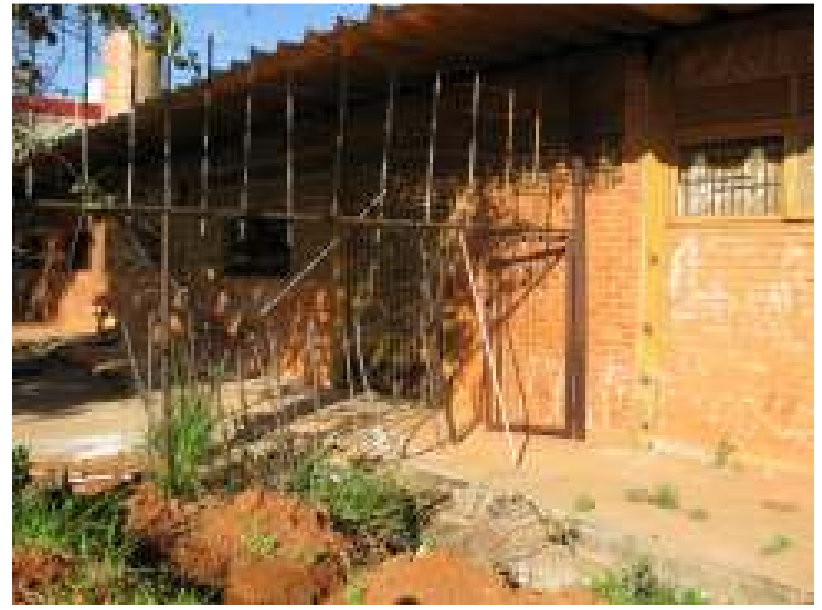

Figura 2 - CEM 4 - Antes da Reforma

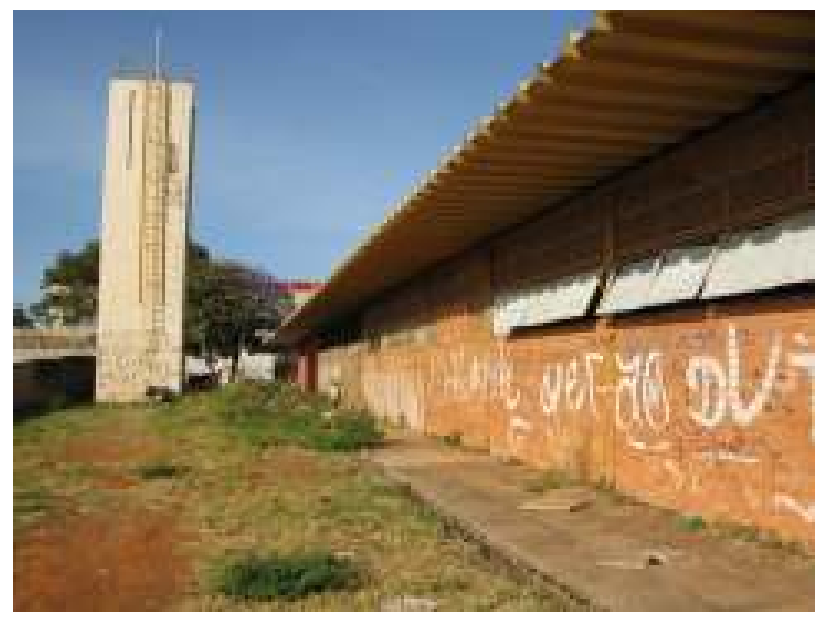

Figura 3 - CEM 4 - Em reforma

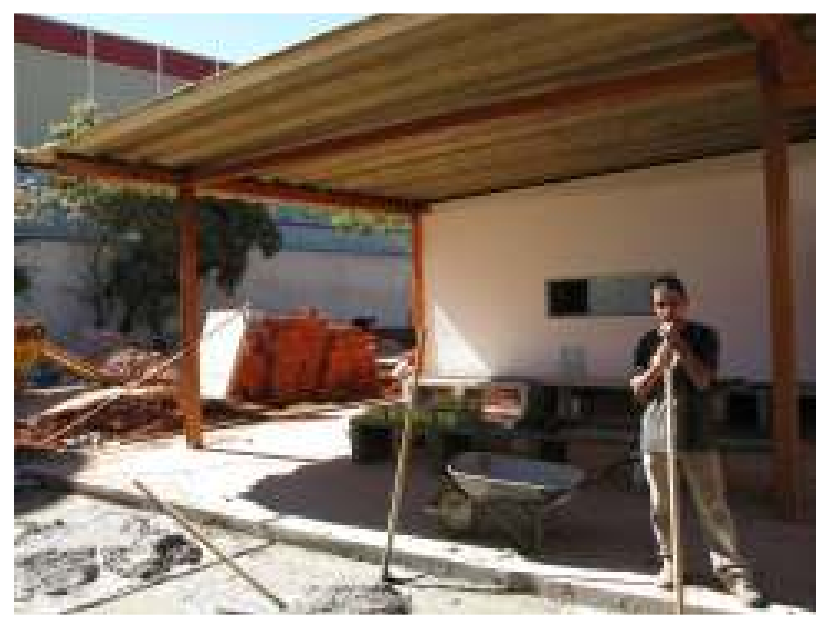


Figura 4 - CEM 4 - Em Reforma

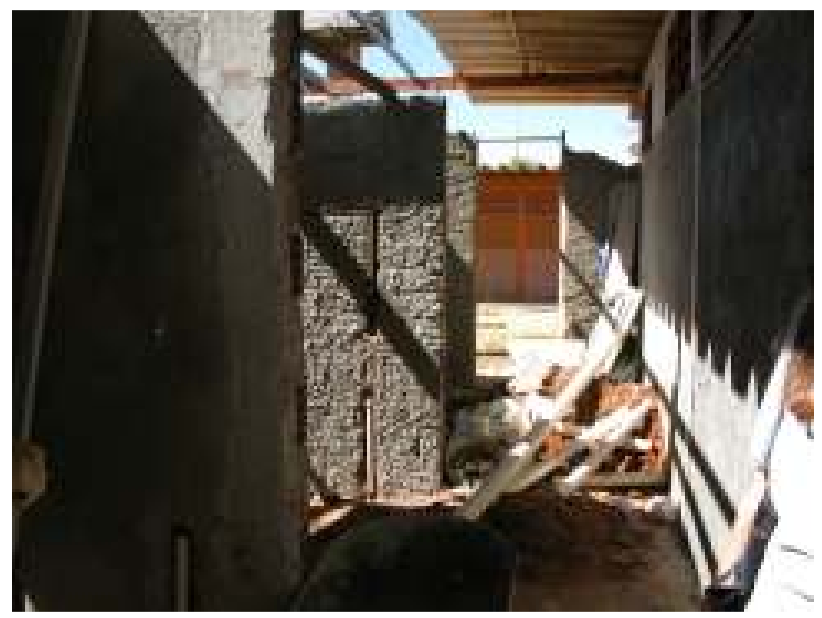

Figura 5 - CEM 4 - Instalações Provisõrias Concluídas

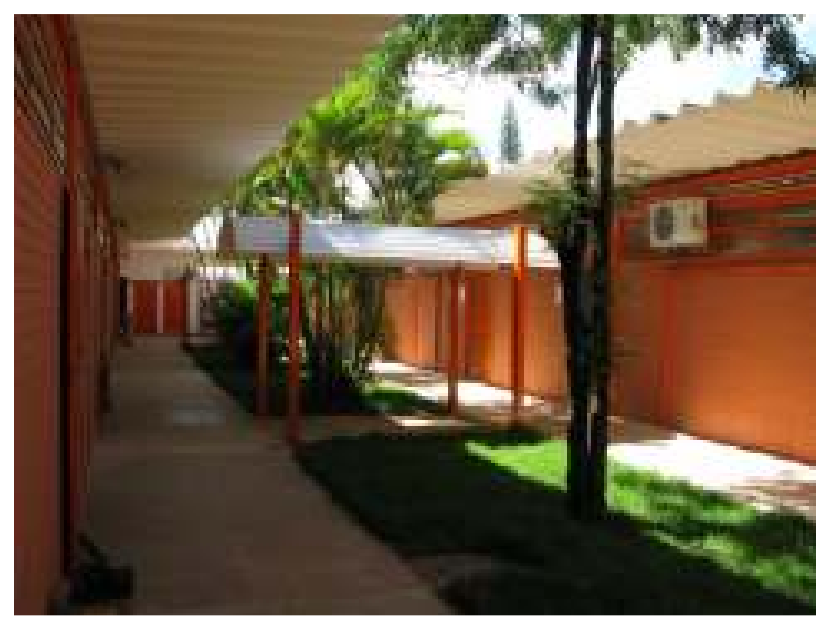

Figura 6 - CEM 4 - Instalações Provisórias Concluídas

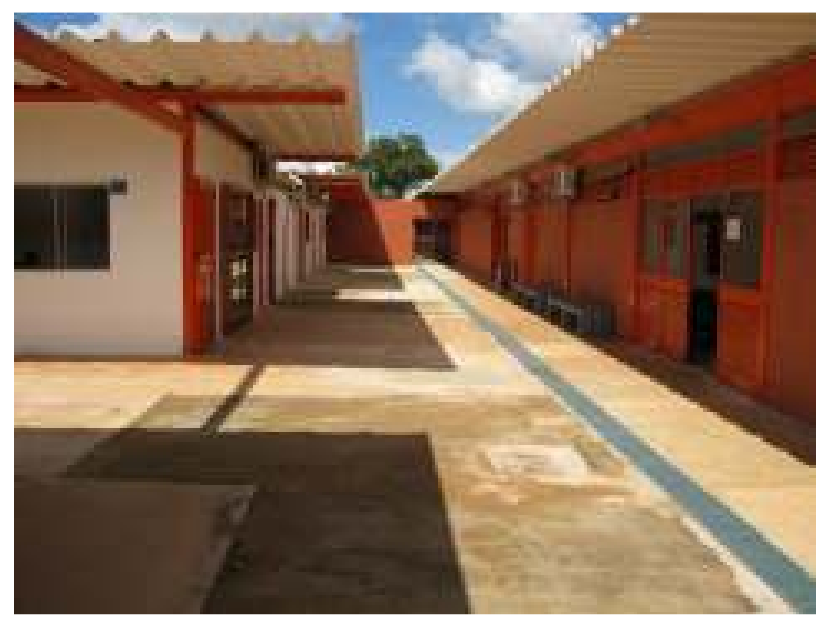


Figura 7 - CEM 4 - Instalações Provisórias Concluídas

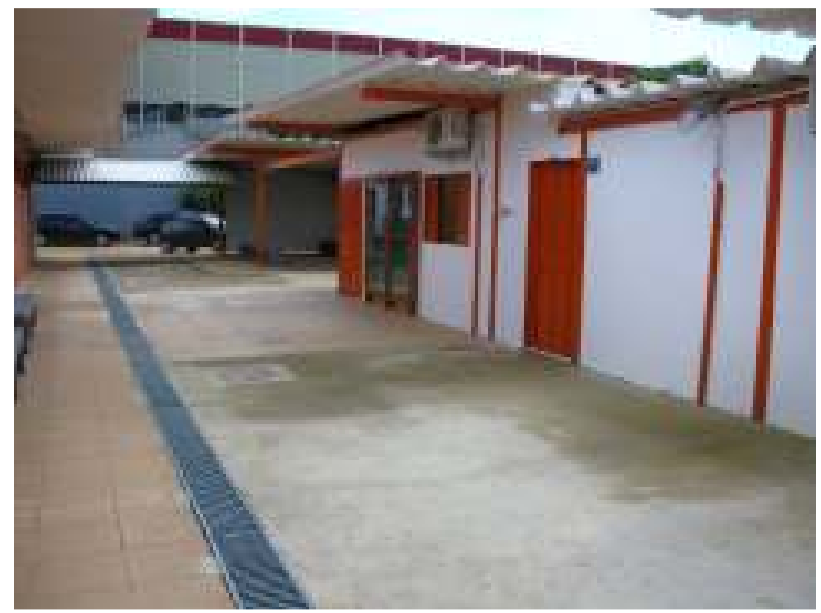

Figura 8 - Entrada - Campi Provisório

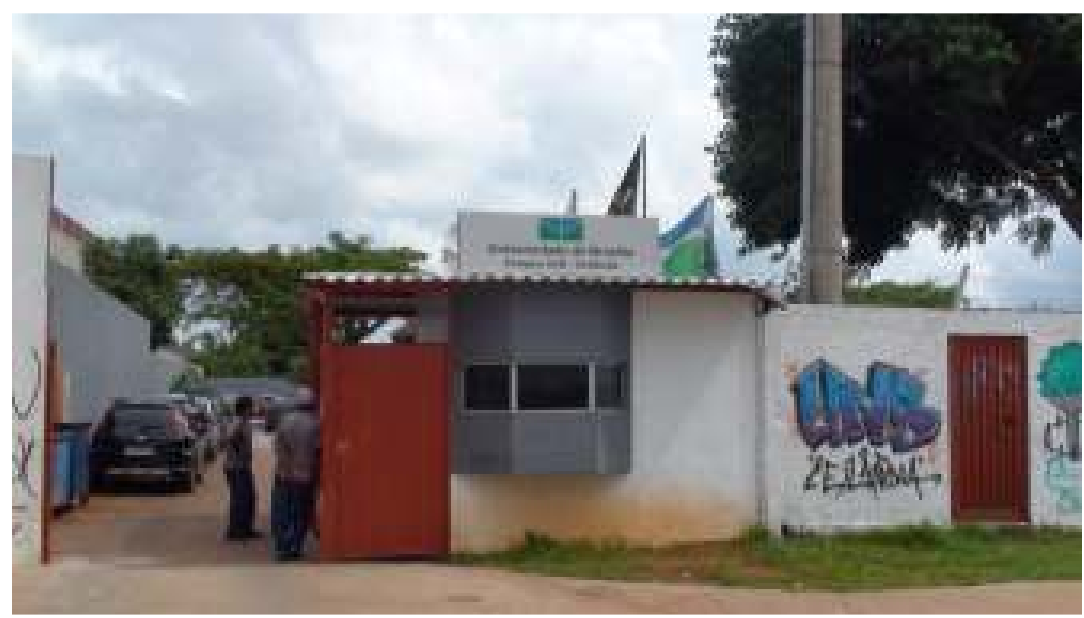

Figura 9 - Primeiros Discentes

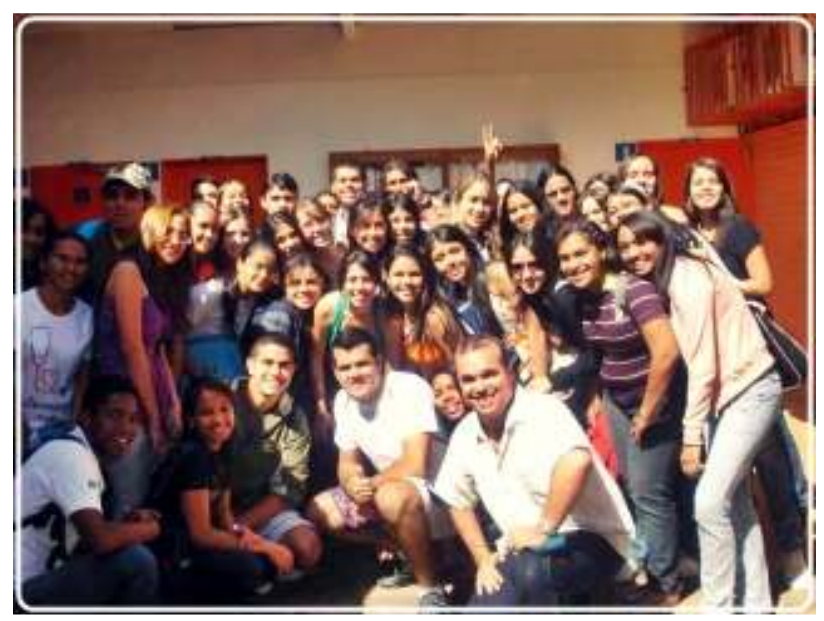


Figura 10 - Movimento dos "Sem Campus"

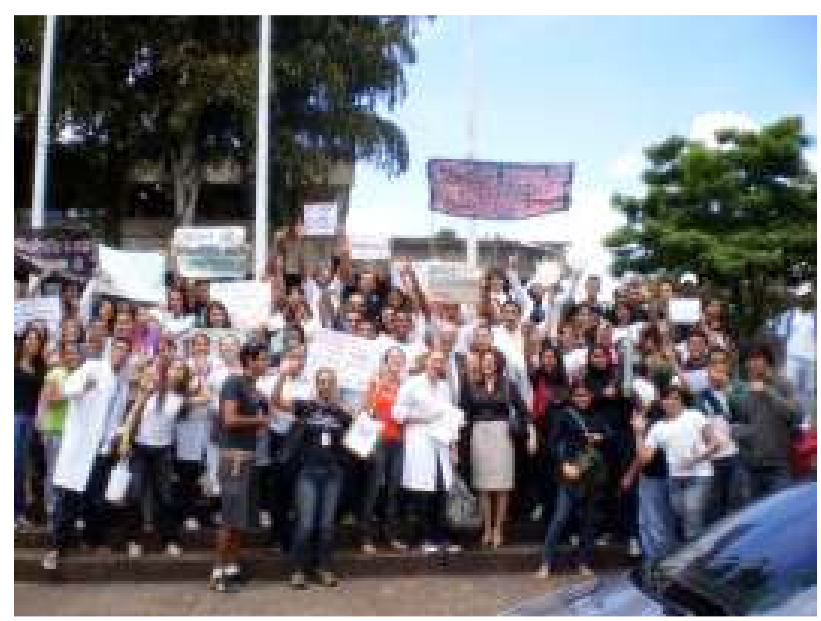

Figura 11 - Movimento dos "Sem Campus"

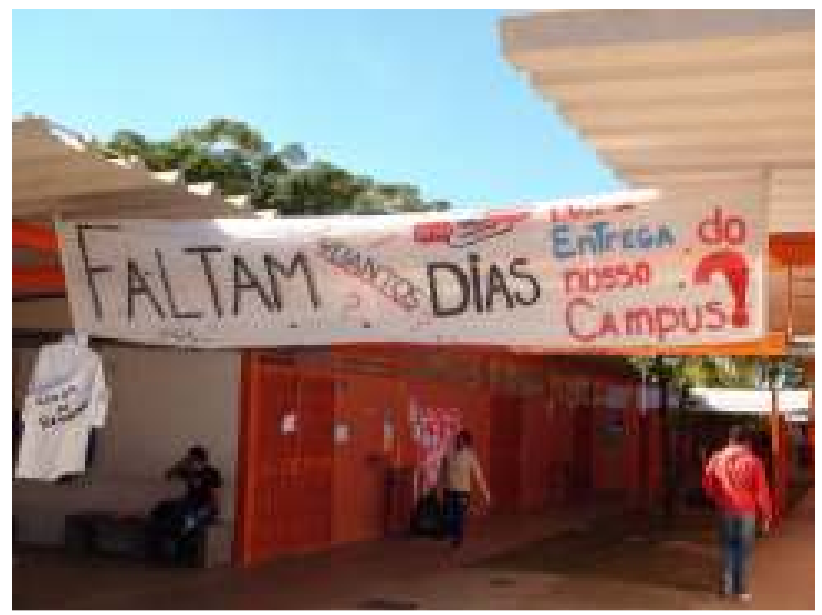

Figura 12 - Flagrante de Sala de Aula

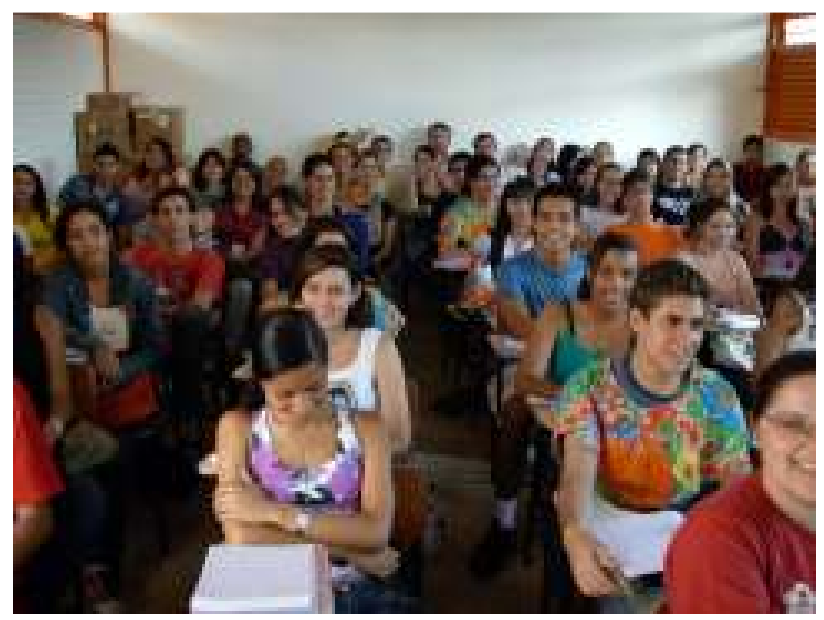


Figura 13 - Aula Prática - Laboratório

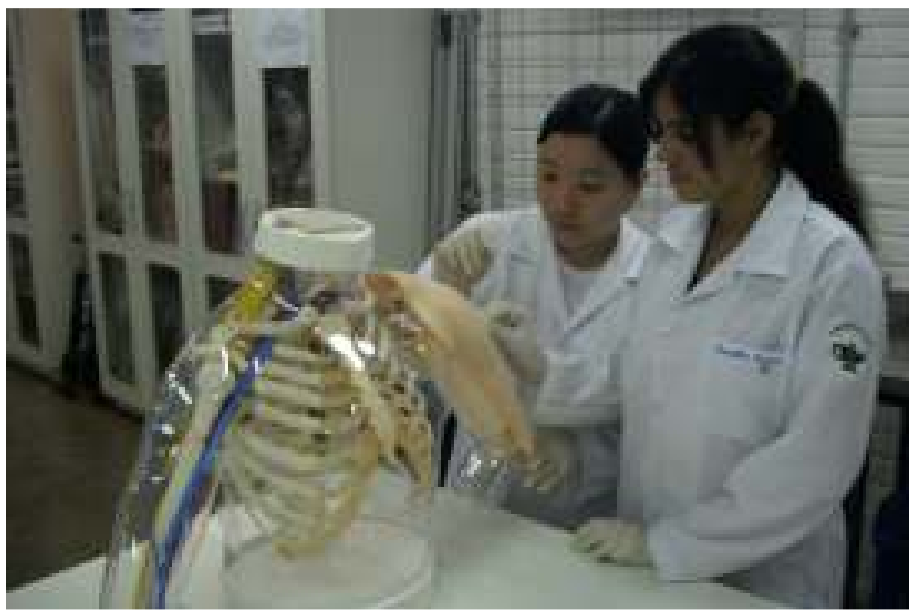

Figura 14 - Visita de Docentes e Servidores às obras do Campi definitivo

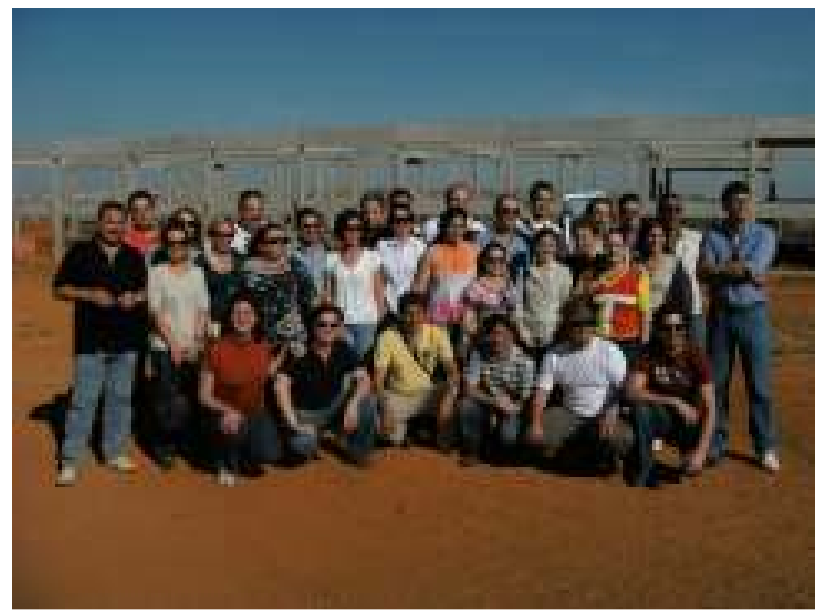




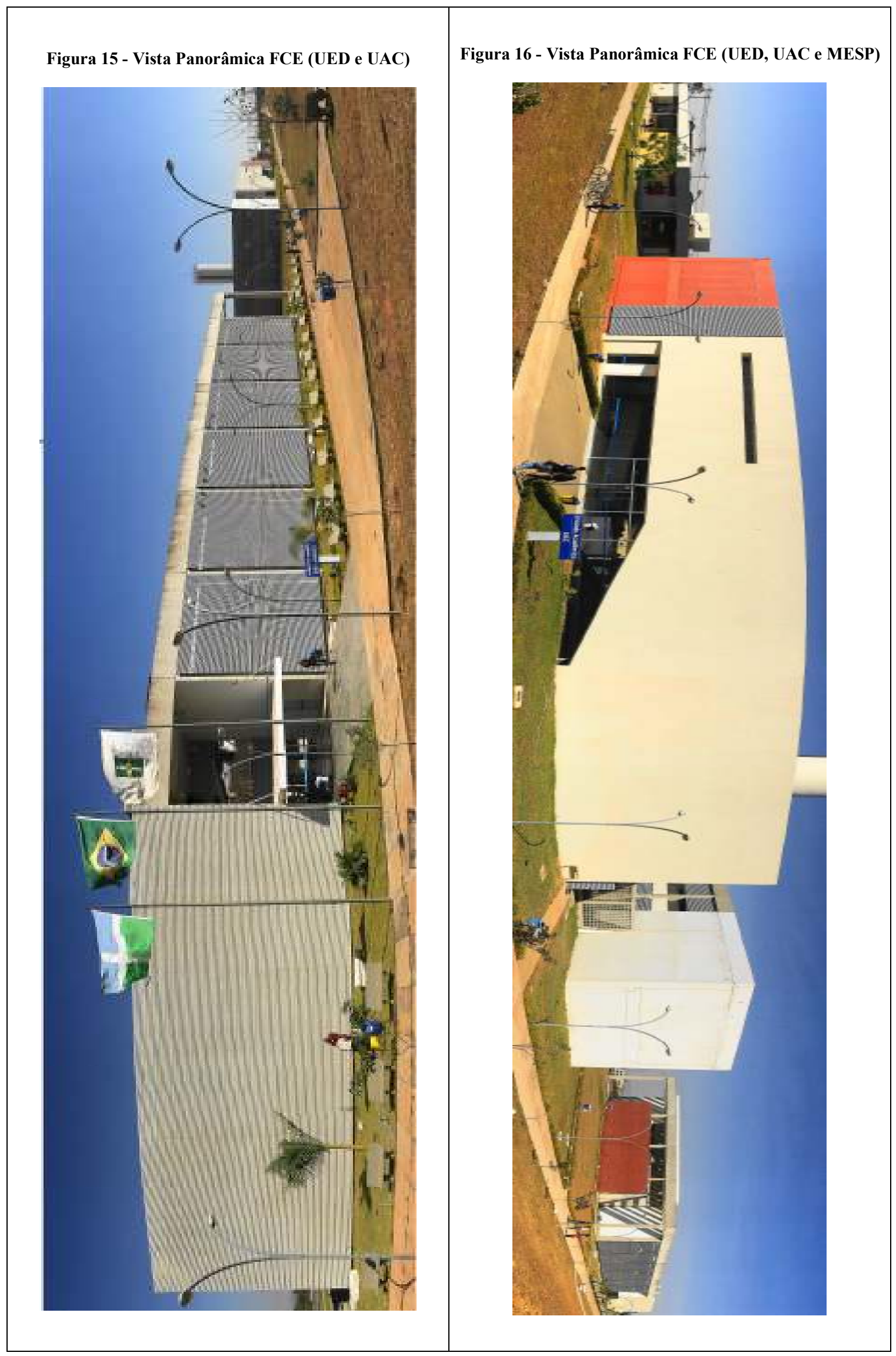


ANEXO B - Termo de Cessão do GDF para UnB

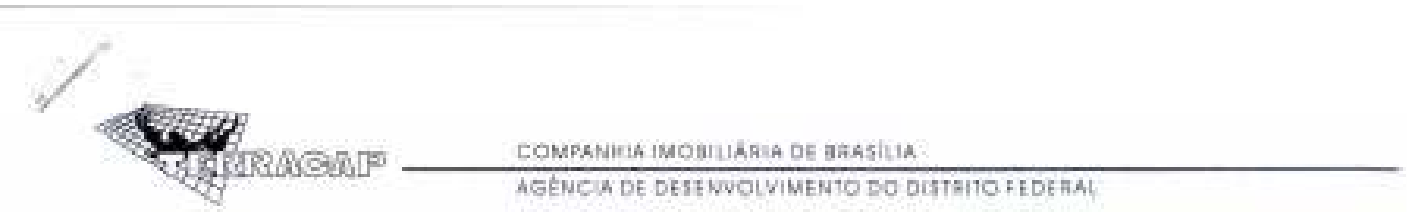

Temo de Ceseáo de Ueo a Titulo Precário que a Companhia Imobilíaria de Brasilia - Terracap faz à Uniāo/Universidade de Brasilia - UNB, na forma abaixo:

Pelo presente instrumento, de um lado, a Companhia Imobiliária de Brasilia Terracap. Empresa Püblica com sede no Setor de Adiministraçào Municipal Bloco 'F", Edificio Terracap, nesta Capital, inscrita na Junta Comercial do Distrito Federal sob o n? $5350000034-8$, CNPJ $n^{2}$ 00.359.877/0001-73, doravante denominada simplesmente Terracap, neste atn representarla por sua Presidente, Maria Júlia Monteiro da Silva, solteira, advogada e por seu Diretor de Desenvolvimento e Comercializaçăo, Antonio Carlos Brasil Teixeira de Carvalho, casado, znotecnista, ambns hrasileiros, portadores das Carteiras de Identidade $n^{\text {ga }}$ 1786-A OABIDF e 6.060.689-SSP/MG e dos CPF $n^{24} 322.085 .026-04$ e 577.054.106-72, respectivamente, residentes e domiciliados nesta Capital, assistidos pelo Chefe da Procuradoria Juridica, Respondendo. Rodrigo Fernandes de Moraes Ferreira. brasileiro, solteiro, advogado, portador da Carteira de Identidade $n^{2} 1.720 .250 / \mathrm{SSP}$ DF e do CPF $n^{2} 701.598 .401-63$, residente e damiciliado também nesta Capital, que examinou todos os dados e elementos do presente termo, sob os aspectos da forma e do conteúdo juridico, conferindo-os e considerando-os em conformidade com a Decisáo $n^{\circ} 896$ da Diretoria Colegiada da Terracap em sua 2424" Sessão, realizada em 11/10/2006, e de outro lado, a Uniāo/Universidade de Brasilia - UNB, Instituiçáo Federal de Ensino Superior, com sede no Campus Universitánio Darcy Ribeiro, nesta Capital, inscrita no CNPJ $n^{2}$ 00.038.174/0001-43, doravante denominada simplesmente Cessionária, neste ato representada pelo seu Reitor. Timothy Martin Mulholland, brasileiro, casado, professor, portador da Carteira de Identidade $n^{2} 1.907 .491-S S P / D F$ e do CPF $n^{2} \quad 150.829 .971-49$, residente e domicillado nesta Capital, tendo em vista o constante do Processo Administrativo $n^{\text {? }}$ 111.001.946/2004-Terracap, resolvem firmar o presente termo, mediante as cláusulas seguintes:

CLAUSULA PRIMEIRA - Do objeto

A Terracap, neste ato e via deste instrumento, cede à Uniâo, para uso da Universidade de Brasilia - UNB uma área de 19.9692 hectares, desmembrada da area de 396,8147 hectares (emanescentes no imóvel de Taguatinga/DF) da Regiabo Administrativa de Ceiländia/DF, conforme Memorial Descritivo constante à fl. 22 do Processa Administrativo $n^{\circ} 111.001 .946 / 2004-T e r r a c a p$

\section{CLÁUSULA SEGUNDA - Da destinaçåo}

O imóvel objeto do presente termo destina-se ao uso exclusivo da Universidade de Brasilia - UNB, sendo defeso à Cessionária dar-the destinaçào diversa da prevista, bem como emprestá-lo ou cedê-lo a qualquer titulo, sob pena de rescisâo do instrumento ora celebrado

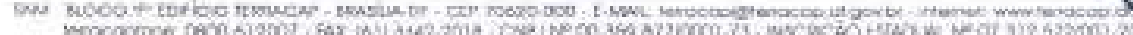




\section{CLÁUSULA TERCEIRA - Da vigência}

O presente termo entrará em vigor na data de sua assinatura e vigerá até que seja concluida a doaçåo do imóvel à Uniảo, por intermedio da Assembléia Geral de Acionistas da Terracap, nos termos da lei.

\section{CLAUSULA QUARTA - Dos encargos}

Responderá a Cessionária por todos os encargos civis, administrativos e tributários que venham a incidir sobre o imóvel objeto da presente cessao de uso, enquanto viger o presente instrumento.

CLẢUSULA QUINTA - Do valor

Pela utilizaçâo do imóvel objeto do presente termo, nenhuma importância será devida pela Cessionária à Terracap, tendo em vista tratar-se de órgáo integrante do Governo Federal

\section{CLAUSULA SEXTA - Da rescisáo}

O presente termo ora ajustado será rescindido, caso ocorra a infringéncia de quaisquer de suas cláusulas ou condiçúes.

\section{CLAUSULA SEETIMA - Do foro}

Fica eleito o foro de Brasilia-DF para dirimir quaisquer dúvidas na execuçáo do presente ajuste.

E, por estarem assim justos e de acordo, assinam o presente em 3 (tres) vias de igual forma e teor, na presença de 2 (duas) testemunhas abaixo nomeadas.

$$
\text { Brasilia-DF, } 11 \text { de outubro de } 2006 .
$$

P/Terracap:

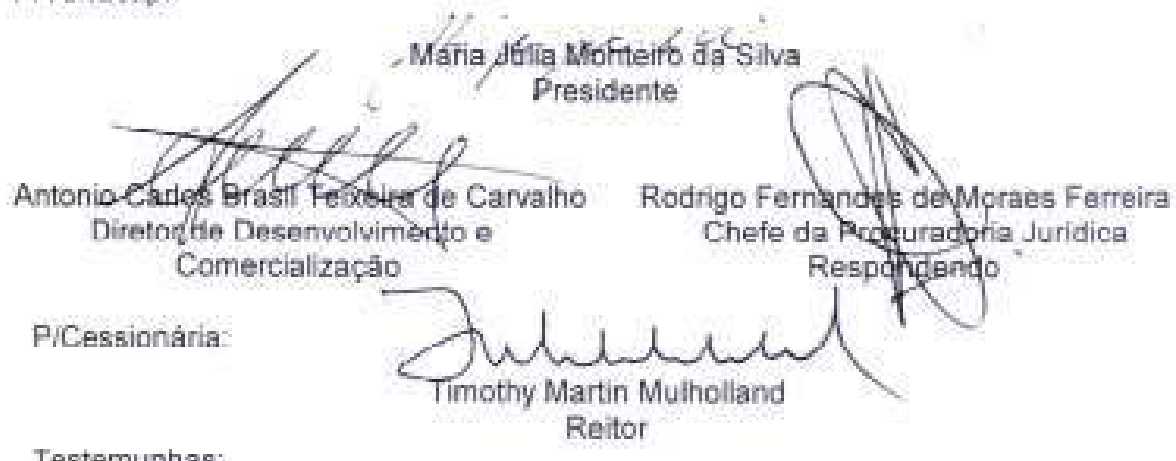

Testemunhas:

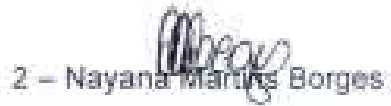

Termo Cessto de Uao - Precitia - 20se - LNA-Ceitindis

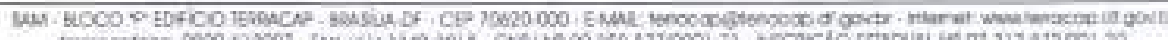

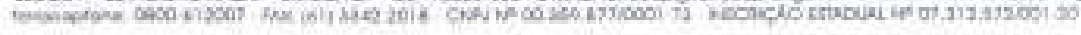


ANEXO C - Acordo de Cooperação entre o GDF e a UnB - Construção dos Campi

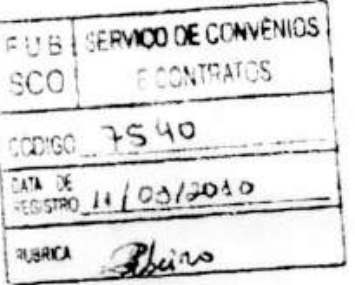

ACORDO DE CCOPERACÄO QLE ENTRE S: CELEBRAM A FUNDACAO UNIVERSIDADE DE BRASILIA - FUB EO DISTRTIO FEDERAL DF OBJETIVANDO A MPLANTACCAO DOS CAMPI DA UNB NA CEILANDIA E NO GAMA

A FUNDACÃO UNIVERSIDADE DE BRASILIA - instituiçăo fecerai de Ensino Sudenor. Fundaçåo Pública criada pela Lei $n^{\circ} 3998$, de 15/12/1961, instituida peló Secreto $n^{\circ} 500$, de 15/01/1962, inscrita no CNPJ sob $n^{\circ} 00.038$ 174/0001-43, com Decreto 500 , de $15 / 01 / 1962$. inscrita no CNP Brasifia, DF neste ato representada sede no Campus Universitario Darcy Ribeiro. Brasitia, OF, por seu Vice Reitor no exercicia da Rello rastente of domiciliado em Brasilia. DF Joáo Batista de Sousa, brasileiro, casado, residente s: dSPMG nomeado celo Ato portador do CPF $n^{\circ} 139.241 .096-72$ e do RG n*103.812 SSP/MG, nomeado pelo Ato da Reitoria $N^{0} 2201 / 2008$ de $13 / 11 / 2008$, publicado no DOU de 21/11/2008, a DISTRITO FEDERAL inscrito nO CNPJ sob o n. $00.394692 / 0001-08$, neste ato representado pelo Governador Wilson Ferreira de Lima, brasilerro, casado, residente epresich 3 domiciliado em Brasilia/OF, portador do CPF SSPIDF , resolvem celebrar o presente ACORDO LE COOPERACAO, Confor autos do Processo n. 23106.007371/2008-26. sujeita 1do-se ao disDosto na ler nit 3.366. de $21 / 06 / 1993$. com suas aiteraçôes postencres, a is clausulas a seguir pactuadas.

\section{CLAUSULA PRIMEIRA - Do cojeto}

O oresente Terno de Cooperaça tem por objeto a cuoveração mutua entre a FUB ? O OF visando ao estabelecimento de oarcena para $\rightarrow$ construçào e amoliacào dos - amor da Ceilandia e co Gama.

$$
\text { GLAUSULA SEGUNDA - DOS Con promissos }
$$

- Do Distrito Federal, por intermedio da Secretana cle Estado de Obras: executar is coras da Unidade de Ensino e Administracalo (UEA) e da Undade de Ensino e Vocéncia (UED) e o gradil do Camous da Ceilandia.

1 - Da Fundacajo Universudade de Brasilia licitar e cantratar is voras para anstrucato da Unidade de Ensino a Administracto (UiEA) e da Unidade te Ensmo e Zocéncia (UED) do Camous do Gama

1 - Dos participes: Licitar a contratar as goras te acordo com os croletos mutetonicos e de instalaçies aoresentados peia FUE

y - Do Distrito Federai: Autorizado por ei distriteil esdecifica. outorgar o usc hodiane concessao de direto real de uso cara al Fundaça Universioade de insitia ate o final da vigencia do oresente Acordo te Cooperacao. a inndade de 
Ensino a Administraçào (UEA) e da Unidade de Ënsino e Docencia (UED) o ote para a imolantação do Campus da Ceilandia.

y - Oo Oistrito Federai: Autorizado por ieı distritai especifica. doar para a Findacio Iniversuade de Brasilia, apos o registro, o lote para a mplantaciao do Ciamnus do Gama

CLAUSULA TERCEIRA - Do Contrcie e Fiscaiizaçào

Fica assegurada a FUB e jo DF a indicaçao de um representante para o exercicio do controle e da fiscalizaçáo sobre a execuçào deste Acordo de Cooperaçào

CLAUSULA QUARTA - Dos Recursos Financeiros

presente instrumento nảo contempla transferencia de recursos financeiros entre os participes.

SUBCLÁUSULA UNICA - As descesas necessánas a consecução do objeto deste instrumento serảo assumicas pelos participes. dentro dos limites de suas respectivas atribuiçōes, nảo podendo os participes nada exigir um do outro

ClAusula quinTA - Da Denuncia e Rescisẫo

$O$ presente Acordo de Ccoperaçäo pocera ser denunciado por incrativa de zuainuer fos particices, mediante troca de avis0s, com antecedencia minma de trinta dias ou rescindido por descumprimento de quaiquer de suas clausulas. assijmindo caca participe os respectrvos onus decorrente das obrigacóes acordadas

CLAUSUlA SEXTA - Da Vigéncia

0 presente Acordo de Cooperaçâo entra em vigor a partir de sua assinatura. com igéncia de dois anos. Dodendo ser prorrogado, mediante termo aditivo por acorro antre as partes.

$$
\text { ZLAUSULA SETIMA - Da Publicaçào }
$$

\footnotetext{
3 presente Instnumento sera publicado, am extrato, seia Findacio Lniversidace de Irasilia e pelo Distrito Federal na imorensa Oficiat, ate o cuinto tia witl do môs aguinte xo ce sua assinatura.
} 
Os casos omissos näo previstos neste Acordo de Cooperacao seráo consuitados as partes por escrito a resolvidos conforme disoosto na legislaçäo aolicavel. am especiat a Let $8.666 / 1993$ e postenores alteraçoes

$$
\text { CLAUSULA NONA - DO ForO }
$$

Fica eieito o Foro da Justiça Federai. Seçăo Judiciária de Brasilia. DF. jara nirimir as questôes surgidas do presente Acordo de Cooperaçāo que nào puderem ser decididas pela via administrativa, renunciando, desde já, a qualquer outro. por mais privilegiado que seja.

E. por estarem assim justos e acordados em suas intençöes, assinam o presente Acordo de Cooperaçáo em duas vias de gual tecr e forma, na uresença das testemunhas abaixo nomeadas que tambem o subscrevem para todos us efeitos isgais

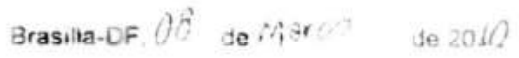
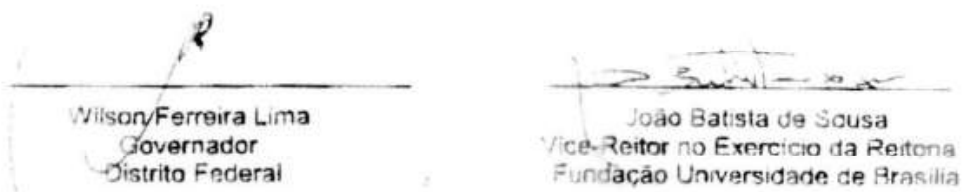

$\rightarrow$

$$
\text { Gistrito Federai }
$$

Fundação Universidade de Arasilia

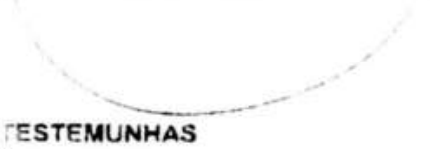

TESTEMUNHAS

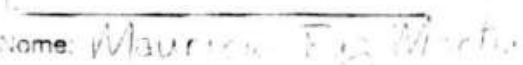

SPF

2.

Yorre

$\because P F$ 
ANEXO D - Termo de Recebimento UED

Fundeça Universidade de Erasilia Centro de Planejamento Oscar Nemeye

PROCESSO N. 83106.0379362011 .77 - CEPLANFUB

CONTRATON=1022/2011 - CEPLANFUB

THRMO DE RECEBIMENTO DEFINITIVO DO OBJETO DO CONTRATO FUB N $=10222011$ CEPLANFLB CELFBRADO ENTRE A FUNDACẢO UNIVERSIDADE DE BRASILIA. FUB E A EMPRESA AMZA CONSTRUTORA LTDA, PARA A OBRA DE CONCLLISĀO DO PREDDIO DESTINADO A UNIDADE DE ENSINO DE DOCENCIA DA FUNDACAO UNIVERSIDADE DE RRASILIA LOCAIIZADA NO CENTRO METROPOLITANO DE CHIINDIA, CONJUNTO A, LOTE 1. CEILANDDA. BRASIL.IA-DF

Tendo sido conchididos ne dia 07/05/2012, os serviços iniciados no dis $3(\mathbf{V} 11 / 2011$, referente a obra de conclusajo do prédio destinado a Linidade de Ensino de Duoćntia da Fundaçăo Universidade de Brasilia localizada no Centro Metrogoitano de Ceilandia. Conjunio A, Lote 1. Ceilatudia, Brasilia - DF, autorizado atravès da Ordeas de Serviço de 01/12/2011, a empresa Amzu Construtora Lida.

Todes os tratulhos foram executados pela contratada acima referida, dentro dos projetos e especificacles determinadas e foram atendidess as exigêneins da fisealizaçò̀ relacionadas no Termo de Recehimento Provisúrio, no Termo dq Recebimento Parcial da obra e at exigéncias desta Comissão Especial de Rescbimento da Obra sendo a altima vistoria realizada em 0.7/99/2014

O presente Termo de recebimento pareial nabo desobriga a contratada de comigir, its suas custas dentro do prano de ginantia deferminado no Art. 618 do Codizo Civil Brasileiro, se for a easo, as defeitos an imperfeiçoss que se venficarem decorrentes de vicios ou mi qualidade, ou ainda de inobserväncia de regna técnicas.

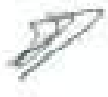

(1) 
Fundacaa Unversidade de Brasilia Centro de Planejamento Oscar Nierneye

De comam asordo, us membros da comissato de recebimento assinam o presente Termo en tots vias de ieual forma e leot.

Brasilia-DF, 10 de Setembro de 2014

\section{COMISSÃO DE RECEBMENTO}

RESOLUCÃO DOB/FUB N."27/2014

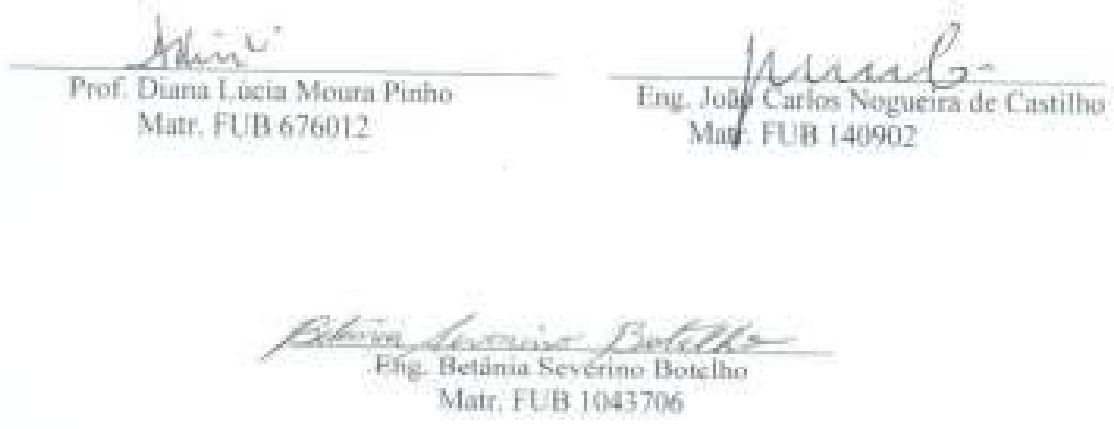

Pela AMZA CONSTRUTORA

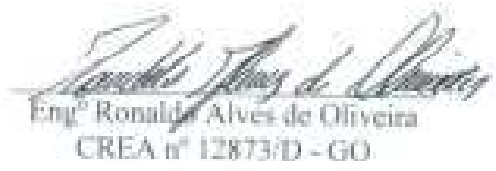


ANEXO E - Termo de Recebimento UAC

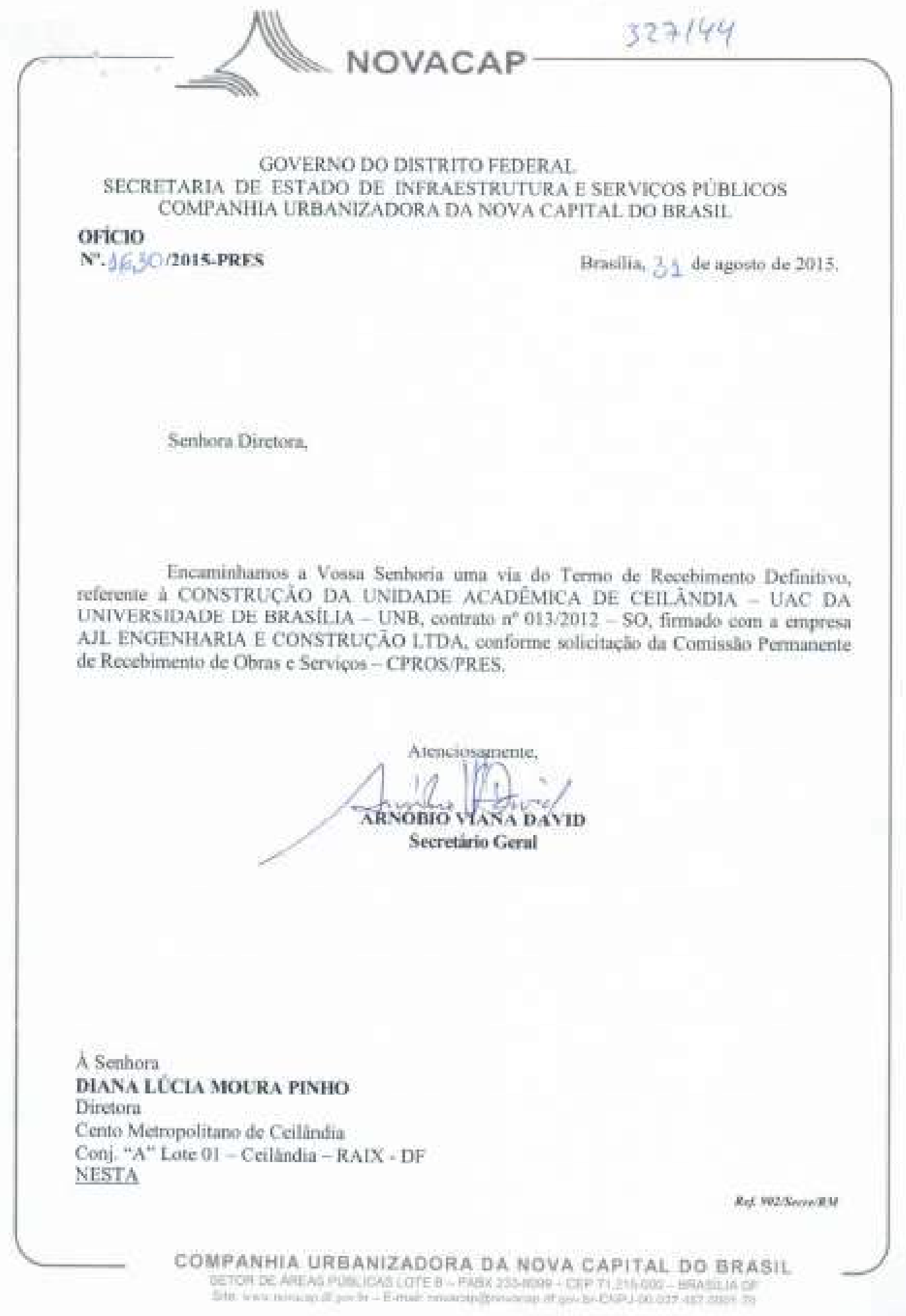


ANEXO F - Termo de Recebimento MESP

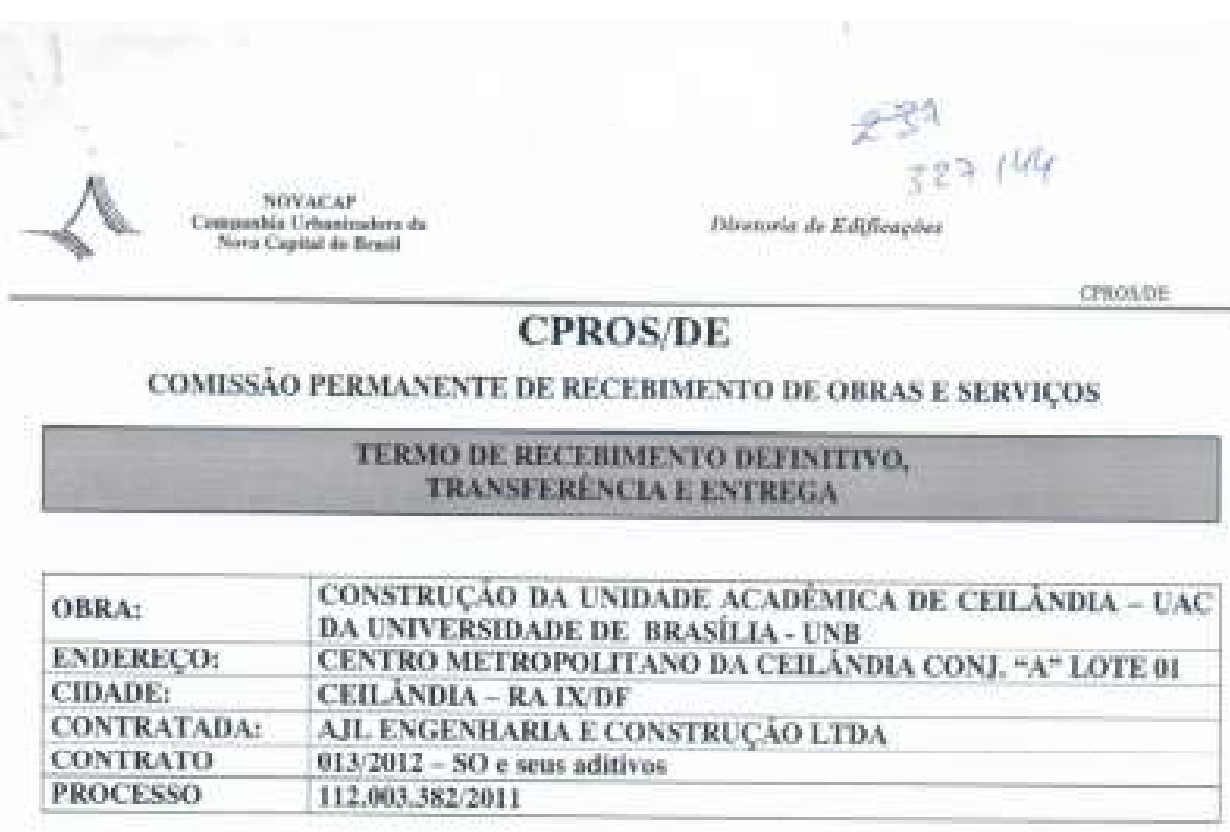

Aos 12 (doze) dias do més de agosto de dois mil e quiaze, presentes de um lado a Compashia Urbanizadora da Nova Capital do Brasil CGC if 00.037.4570001-70, daqui per dismie denomisada NOVACAP, representada pela Comissấo Pemanente de Reoebümento de Obras e Serviços - CPROSIPRES, constituida por, Enge. Paulo Afonso Ribeiro de Freitas (Presidenie). Ené". Punlo Roberto de Castro (Chefe do SERFODEDI/DE), Enger- Reinaldo Rodrigues (Fiscal do SERFO/DEDI/DE), Eng". Antonio Carlos Ribeiro Silva (Representabte da Sectetaria de Estado de Iníraentrutura e Servigas Püblicos do DF - SINESP), Prof", Dianu Liecia Mouna Pinho (Diretora do Cumpus UNB - Ceilăndia), Enge'. Henrique Ewerton Pires (Diretor de Obras da UNB) e de outro lado a empresa A.IL ENGENHARIA E CONSTRUCČ̉O LTDA., dą̧ui por diante denoininada Contratada, Tepresentada pelo Eng". Luciano de Scura Maciel Pires, procederam, em afendimento ao constante no processo $\mathrm{n}^{0}$. 112.003.382/2011, a conferếncia da obra acima refereaciada, execurada pela Empreiteira, com recursos provetientes do Contrato $\pi^{2} .013 / 2012$ - So. de 14,06/2012, publicado ao Diáriò Oticial do Distrito Federnal em 15/06/2012, pieg 54, do Convênio n".155/2009 - SONOVACAP. de 26/08/2009, publicado no Diárid Oficial do Distrito Federal em 23/06/2009, pagg 85, conforme Nota

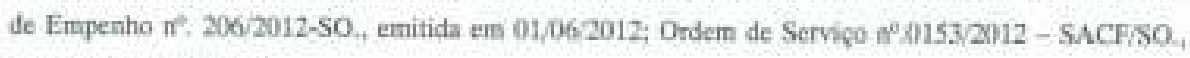
emitida em 15:/6/2012.

Na vcasilo, os representantes receberan $a$ obma, de acordo com o contrato acima $f$ citade, em conformidade com os projetos, espefificfçes o demais documentos toenicus anskim

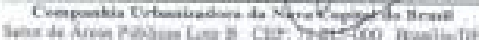

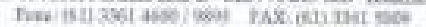

cocsongraczom. Th

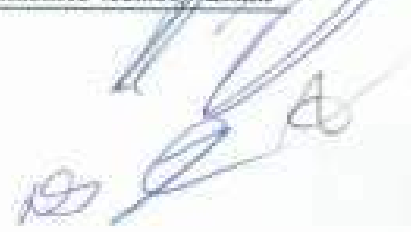




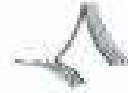

vovicar

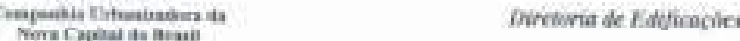

come foi levado em consideraçäo o Termo de Recebimento Provigório, lavrado pela fiscalizaç̄o em 01008/2013 de acordo com o estabelecido na Lei na 8665/93.

Assim sendo, os representantes acima nomeados, NOVACAP e Secretaria de Estado de Infraestrutura e Serviços Publicos do DF - SINESP, com base na mencionada lei, farem o Recebimenta Definitivo e ainda a Transferśncia e Entrega da obna em epigrafe, a Universidade de Brastifia - UNB, sem a apresentaçỉo da Carta de Habite-ke, ficando no entanto, a eirupresa Coetratada, a abrigacio de apresentar tal documento (Habite-sek, tâo logo sejam sanadas as pendências quanto a documentaço de. Titularidade Regularidade cadastral, da irea onde foi executafla a obra,objetu de contraio

Em decorrelocia poderắo ser literados a cauçắs e os respectivos reforços depositudos pela cotitratada, de conformidade com a clíasala aena do Contrato

Pam firmeza do que acisa ficou dito, as partes nomeadas firmam ede Termo.
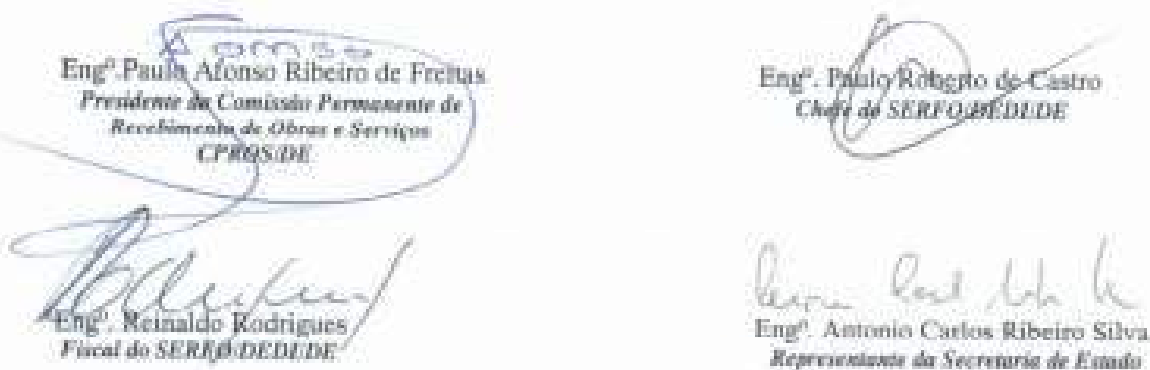

Eng? Antonio Carlas Ribeiro Silva Reporrovedeste da Secrenarie de Einade

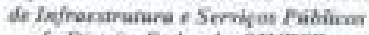
di Dienio Fedrral - STEEs?

theces

Profe Diana Lucia Moara Pinhe Duremane do Campes LNB Crilindia

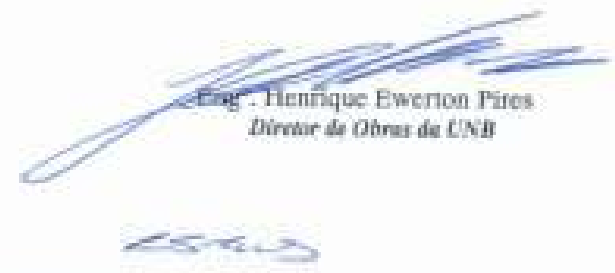

Eng". Luciano de Sowza Macicl Tries

Fepresientanite de Contrainds

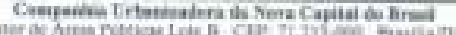

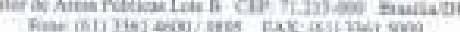

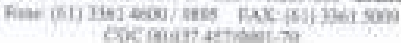




\begin{abstract}
TERMO DE RECEBIMENTO DEFINITIVO DO OBNETO DA CONCORRENCLA DO OBJETO DO CONTRATO FUB N:216:2010 - CIPLANTEB CEIEBRADO ENTRE A FUNDACAO UNIVERSIDADE DE BRASIULA - IUB E A EMPRESA COMBRASEN - COMPANHIA BRASILLIRA DE SOLUCÓES EM ENGENHARIA ITDA, PARA A OBRA DE CONSTRUCĀO DE (UM) PREDLO DESIINADO AO MÓDULO DE SERVICOS E FQUIPAMENTOS ESPORTIVOS MESP, LOCALIZADO NO CENTRO MHTROPOLITANO DE CEIL ANDIA, CONJUNTO A. LOTE 1, CFII ẢNDIA, BRASILLA-DE.
\end{abstract}

Tendo sido concluida a obra em dia 03/05/2012, is

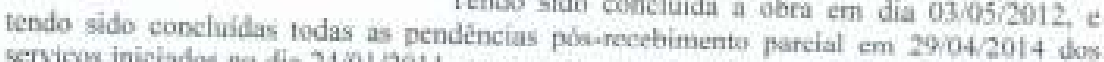
servicos iniciados no dia 24:01/2011, eom as protrogupdes de prazo devidamente aprovada pelo CEPLANFUB, o objeto da Concorrincia No 216/2010. CEPL.AN/FUB, referente a obru de Construçäo de 1 (um) Predio destinado ao Mödulo de Serviçs e Fquipamentos Enportivos - MESP da Faculdade UnB Ceilindia, localizada no Centro Metropolitano de Serviço de $1401 / 201$. Lote 1, Ceilándia, Brasilia - DF, autorizada utravés da Ordem de Fngenharia La consecilemetemente trabalhos foram considerados em crndiçōes de accitaçlo definitiva e consequerticmente lavrado o presente Temis de Recebimento Definitivo.

contratada acima referida, denim dosos os trabalkos foram executados pela atendidas as exítèncias da fiscalizacho projetas $e$ espocificaçóes determinadas e foram na eorrespondência da datada de 25 de juahe de 2012 destu Recebimento Provisuleio, Revebimento de Ohta relacionadu. 25 de junho de 2012 destu Comissän Especial de outubro dezembro de 2013 . desobriga a contratada de comigis, as vuas custes dermo de recebimento definitivo nilo no. Art. $6: 8$ do Cósfipo Civil Brasileiro, se for o caso, do prazo de garnntia determinado

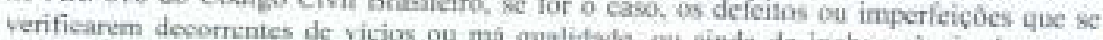
tecticas.

De camum aconds, os membros
resebimento assinam o presente Termor em thes vias de igtal forma e teor.

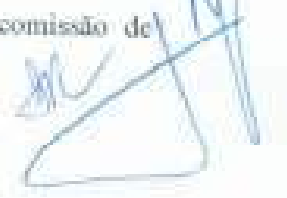




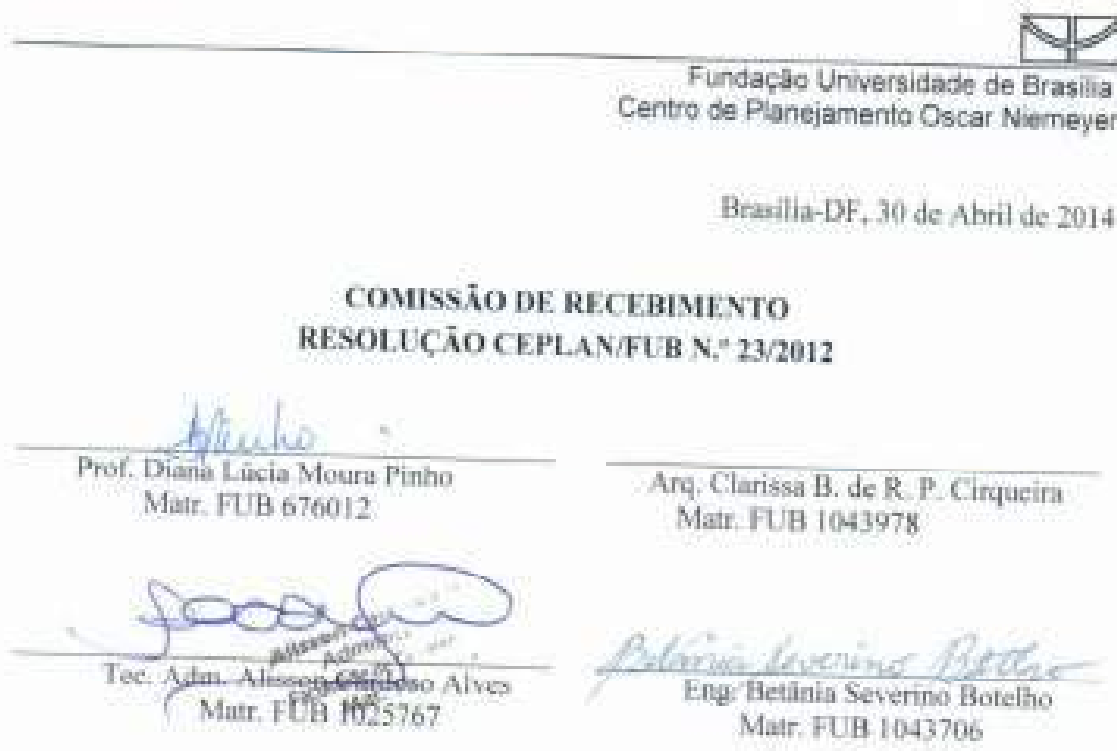

Pela COMBRASEN - Companhia Brasileirzude Solucóes em Engenharia L tda

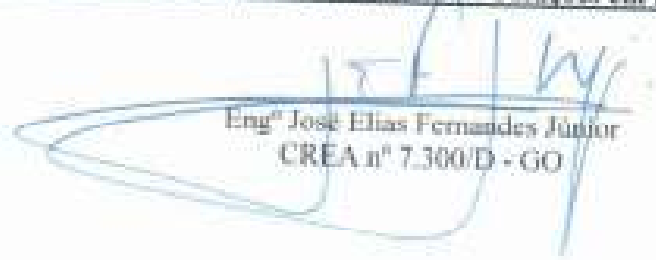


ANEXO G - Questionário

Universidade de Brasília

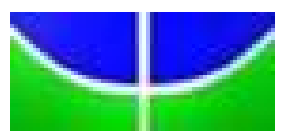

Faculdade de Economia, Administração e Contabilidade e Gestão de Políticas Públicas FACE - Departamento de Economia

Programa de Pós-Graduação em Economia e Gestão do Setor Público

\author{
Questionário BENEFICIÁRIO (A)
}

\title{
Caro Beneficiário,
}

Ao responder as questões abaixo, você estará contribuindo para o desenvolvimento da pesquisa, cujo objetivo é entender a contribuição da Faculdade de Ceilândia, em particular, o projeto de Extensão XXXXXXXXXXXXXXXXXXXX.

Desde já agradeço a sua disponibilidade!

Você não precisa se identificar.

Os dados coletados por meio deste questionário serão utilizados, somente, para fins de pesquisa.

$\left.1^{\circ}\right)$ Qual o seu sexo?

( ) Masculino ( ) Feminino

$\left.2^{\circ}\right)$ Qual dessa faixa etária você se enquadra?

( ) até 30 anos ( ) entre 31 e 50 anos ( ) acima de 51 anos

$\left.3^{\circ}\right)$ Cidade onde reside?

( ) Ceilândia ( ) outras

$4^{\circ}$ ) Qual a sua renda?

() até 2 salários ( ) entre 3 e 5 ( ) Outros

$\left.5^{\circ}\right)$ Nível de satisfação com o projeto?

( ) Insatisfeito ( ) Satisfeito ( ) Muito satisfeito

$\left.6^{\circ}\right)$ Como teve conhecimento do projeto?

$7^{0}$ ) Você trabalha? ( ) Sim ( ) Não

8) Antes do Projeto, tinha algum acompanhamento?

() $\operatorname{sim}$ ( ) Não

Se Sim onde:

9 Comparada antes do início do acompanhamento, como você classificaria sua saúde geral, agora?)

( ) muito melhor ( ) pouco melhor ( ) mesma coisa ( ) pior

$1^{\circ}$ ) Faça um breve comentário sobre a importância da UnB na Ceilândia, e do Projeto? 